Aus der Abteilung Humangenetik

(Prof. Dr. med. Dr. h.c. W. Engel)

Im Zentrum Hygiene und Humangenetik

der Medizinischen Fakultät der Universität Göttingen

\title{
Zur Rolle von Stra8 in pluripotenten Stammzellen
}

\author{
INAUGURAL- DISSERTATION \\ zur Erlangung des Doktorgrades \\ der Medizinischen Fakultät \\ der Georg-August-Universität zu Göttingen
}

\author{
vorgelegt von \\ Linda Kotzenberg \\ aus Steinheim
}

Göttingen 2010 
Dekan:

I. Berichterstatter: $\quad$ Prof. Dr. med. Dr. h.c. W. Engel

II. Berichterstatter/in: Priv.-Doz. Dr. rer. Nat. Behr

Tag der mündlichen Prüfung: 25.01.2011 


\section{INHALTSVERZEICHNIS}

Inhaltsverzeichnis I

Abbildungs- und Tabellenverzeichnis $\quad$ V

Abkürzungsverzeichnis $\quad$ VII

1. EINLEITUNG 1

2. MATERIAL UND METHODEN 5

2.1 Materialien 5

2.1.1 Chemikalien 5

$\begin{array}{ll}2.1 .2 \text { Gebrauchswaren } & 7\end{array}$

2.1.2.1 Allgemeine Gebrauchswaren $\quad 7$

2.1.2.2 Gebrauchswaren für die Zellkultur 7

2.1.3 Geräte 8

2.1.4 Sterilisation 9

2.1.5 Puffer und Lösungen 9

2.1.6 Gebrauchsfertige Reaktionssysteme 11

$\begin{array}{lll}2.1 .7 & \text { Vektoren } & 12\end{array}$

2.1.8 Bakterien 12

2.1.8.1 Medien für die Bakterienkultur 12

2.1.9 Mausstämme 13

$\begin{array}{ll}2.1 .10 & \text { Eukaryotische Zellinien }\end{array}$

2.1.10.1 Medien für die Zellkultur 13

$\begin{array}{ll}2.1 .11 \text { Antikörper } & 15\end{array}$

$\begin{array}{ll}2.1 .12 \text { Sonden } & 15\end{array}$

$\begin{array}{lll}2.1 .13 & 15\end{array}$

2.1.13.1 Primer für RT- PCR 15

2.1.13.2 Primer für die Sequenzierung 16

$\begin{array}{ll}\text { 2.1.13.3 Andere Primer } & 16\end{array}$

$\begin{array}{ll}2.1 .14 \text { Molekulargewichtsstandard } & 16\end{array}$

$\begin{array}{ll}2.1 .15 & 16\end{array}$ 
2.2 Zellbiologische Arbeitsmethoden

2.2.1 Kultivierung von eukaryotischen Zellen

2.2.1.1 Kultivierung von murinen embryonalen Stammzellen (ES- Zellen)

2.2.1.2 Kultivierung von "multipotent adult Germline Stem Cells" (maGSCs)

2.2.1.3 Kultivierung von murinen embryonalen Fibroblasten

2.2.2 Isolation von murinen embryonalen Fibroblasten

2.2.3 Auftauen und Einfrieren von eukaryotischen Zellen

2.2.4 Passagieren von eukaryotischen Zellen

2.2.5 Gelatine- Behandlung von Kulturgefäßen

2.2.6 Mitomycin- Behandlung von embryonalen Fibroblasten

2.2.7 Induktion von eukaryotischen Zellen mit Retinsäure 20

2.2.8 Herstellung einer testikulären Zellsuspension 20

2.2.9 FACS- Sortierung 20

\subsection{Histologische Arbeitsmethoden 21}

2.3.1 Fixierung von Zellen und Geweben 21

2.3.1.1 Fixierung von Zellen mit Paraformaldehyd 21

2.3.1.2 Fixierung von Organen und Geweben 21

2.3.2 Färbung von Zellen und Gewebeschnitten 21

2.3.2.1 Immunzytochemische Färbung von eukaryotischen Zellen 21

2.3.2.2 Immunhistochemische Färbung von Gewebeschnitten 22

\subsection{Molekularbiologische Arbeitsmethoden 22}

2.4.1 Klonierung von DNA- Fragmenten 22

2.4.1.1 Spaltung von DNA durch Restriktionsendonukleasen 22

2.4.1.2 Dephosphorylierungen von Plasmid- Vektoren 23

2.4.1.3 Ligation von PCR- Produkten in PGEM-T Easy 23

2.4.1.4 Ligation von PCR- amplifizierten DNA- Fragmenten 24

2.4.1.5 Transformation kompetenter Escherichia- coli- Zellen
mittels Hitzeschock

2.4.2 Isolierung von Nukleinsäuren 24

2.4.2.1 Minipräparation von Plasmid- DNA aus Escherichia coli 
2.4.2.2 Endotoxin- freie Maxipräparation von Plasmid- DNA aus Escherichia coli

2.4.2.3 Isolierung von genomischer DNA aus eukaryotischen Zellen

2.4.2.4 Isolierung von genomischer DNA aus Geweben

2.4.2.5 Isolierung von Gesamt- RNA

2.4.2.6 Isolierung von Gesamt- RNA aus eukaryotischen Zellen

2.4.2.7 Isolierung von RNA aus Geweben

2.4.2.8 Isolierung von RNA aus Embryonen

2.4.3 Herstellung von komplementärer DNA durch Reverse Transkription

2.4.4 Konzentrationsbestimmung von Nukleinsäuren 28

2.4.5 Gelelektrophoretische Methoden 29

2.4.5.1 Agarosegelelektrophorese von DNA 29

2.4.5.2 Agarosegelelektrophorese von RNA 29

2.4.6 Aufreinigung von DNA 30

2.4.6.1 Linearisierung und Aufreinigung von Konstrukten vor der Transfektion

2.4.6.2 Isolierung von DNA- Fragmenten aus Agarosegelen

2.4.7 Polymerase- Kettenreaktion (PCR) 31

2.4.7.1 PCR an Plasmid- DNA 32

2.4.7.2 PCR an genomischer DNA 33

2.4.7.3 RT-PCR 33

2.4.7.4 Sequenzierung von PCR- Produkten 33

2.4.8 Radioaktive Markierung von DNA ("random prime labelling") 34

2.4.9 Transfertechniken und Hybridisierung $\quad 35$

2.4.9.1 Transfer von RNA aus Agarosegelen: NorthernBlotting

2.4.9.2 Radioaktive Hybridisierung von Northern- Blots 35

2.4.9.3 "Strippen" von Membranen 36

2.5 Embryologische Methoden 36

2.5.1 Blastozysteninjektion 36 
2.5.2 Superovulation von Mäusen und Gewinnung von Oozyten

2.5.3 Isolierung von Präimplantationsembryonen

\section{ERGEBNISSE}

3. 1 Expressionsanalyse von Stra8

3.1.1 Nachweis der Stra8- Expression im Ovar mittels RT- PCR

3.1.2 Immunhistologischer Nachweis der STRA8- Expression im Ovar und im Testis

3.1.3 Nachweis der Stra8- Expression in den ESC- und SSC- Zelllinien

3.1.4 Stra8- Expression in Embryonen

3.1.5 Immunhistochemischer Nachweis der STRA8- Expression in Präimplantationsembryonen

3.2 Untersuchung der Rolle von Stra8 bei der Pluripotenz

3.3 Bestimmung des prozentualen Anteils an Stra8- positiven Zellen im Testis der transgenen Stra8/EGFP-Maus

3.4 Stra8- Überexpression

\section{DISKUSSION}

4.1 Das Gen Stra8

4.2 Stra8- Expressionsmuster und seine Rolle in der Meiose

4.3 Stra8- Expression in pluripotenten Zellen

4.4 Perspektiven 


\section{Abbildungs- und Tabellenverzeichnis}

Abb.1: Stra8-RT- PCR mit cDNA aus 15 Tage alten und adulten WT- Ovarien

Abb.2: STRA8- Antikörperfärbung auf Paraffinschnitten von WT- Testis .40

Abb.3: STRA8- Antikörperfärbung auf Paraffinschnitten von WT- Ovarien verschiedenen Alters $.41+42$

Abb.4: Stra8- RT-PCR mit cDNA aus vier SSC- Zelllinien und aus der ES- RI Zellline

Abb.5: Stra8- RT- PCR mit cDNA aus sieben verschiedenen

ES- Zelllinien

Abb.6: Northern- Blot mit RNA aus den Zelllinien

ES C57BI und SSC C57BI

Abb.7: STRA8- Antikörperfärbung auf SSC- und ES- Zelllinien $45+46$

Abb. 8: RT- PCR- Expressionsanalyse für Stra8 mit cDNA aus

differenzierten und undifferenzierten Zellen

Abb.9: RT- PCR- Expressionsanalyse für Stra8 und Zfp206

in Embryonen (50).

Abb.10: RT- PCR- Expressionsanalyse für Stra8 und Zfp206

in Embryonen (100). .50

Abb.11: STRA8- Antikörperfärbung auf

Präimplantationsembryonen $.51+52$

Abb.12: EGFP- Fluoreszenz der ES RI Stra8/10 nach FACSortierung.

Abb.13: Chimären entstanden aus den EGFP ${ }^{+}$- Zellen $.53+54$

Abb.14: Genotypisieruns- PCR der braunen Nachkommen (F1) der Stra8/EGFP- Chimären. .55

Abb.15: FACScanning EGFP-positiver Zellen aus der Testissuspension 14 Tage alter und adulter transgener Stra8/EGFP- Mäuse. 
Abb.16: EGFP- Fluoreszenz in Testis und Ovar aus Stra8/EGFP- transgenen Mäusen .57

Abb.17: Darstellung des pCMV- Myc- Vektors und der Ligations-

Strategie für die Hygromycin- Resistenz- Kassette. .59

Abb.18: Amplifikation des Stra8-ORFs. .59

Abb.19: Verdau von Plasmidpräparationen von pGEM-T EasyORF- Stra8 mit dem Restriktionsenzym NotI (1-10). 60

Abb.20: Verdau von Plasmidpräparationen von pCMV- MycHyg- ORF- Stra8 mit dem Restriktionsenzym NotI (1-10). .60

Abb.21: Struktur des STRA8- Proteins. .66

Tab.1: Aufzählung von Keimzell- spezifischen Genen, die im Zusammenhang mit den pluripotenten Eigenschaften von Zellen stehen. 2

Tab. 2: Ergebnisse der Blastozysteninjektionen .54 


\section{Abkürzungsverzeichnis}

Abb.

Abbildung

bp

Basenpaare

$\mathrm{Bq}$

Becquerel

BSA

Rinderserumalbumin

bzw.

beziehungsweise

${ }^{\circ} \mathrm{C}$

Grad Celsius

cDNA

komplementäre DNA

$\mathrm{Ci}$

Curie, $1 \mathrm{Ci}=3,7 \times 10^{10}$ Becquerel

$\mathrm{cm}$

Zentimeter

CMV

Zytomegalievirus

$\mathrm{CO}_{2}$

Kohlenstoffdioxid

d

Tag

DAPI

4',6'- Diamidino- 2- Phenylindolhydrochlorid

dATP

Desoxyadenosintriphosphat

dCTP

Desoxycytidintriphosphat

$\mathrm{ddH}_{2} \mathrm{O}$

bidestilliertes Wasser

ddNTP

Didesoxyribonukleosid- Triphosphate

DEPC

Diethylpyrocarbonat

dGTP

Desoxyguanosintriphosphat

$\mathrm{dH}_{2} \mathrm{O}$

Destilliertes Wasser

DMEM

Dulbecco's Modifiziertes Eagle Medium

DMSO

Dimethylsulfoxid

DNA

Desoxyribonukleinsäure

DNase

Desoxyribonuklease

dNTP

Desoxynukleosidtriphosphate

dPBS

Destillierte Phosphatgepufferte Salzlösung

dpc

$\mathrm{dpp}$

"days post coitum"

"days post partum"

$\mathrm{dt}$

doppeltransgen

DTT

Dithiothreitol

dTTP

Desoxytymidintriphosphat 


\begin{tabular}{|c|c|}
\hline EDTA & Ethylendiamintetraacetat \\
\hline EGC & "Embryonic Germ Cell" \\
\hline EGFP & "Enhanced Green Fluorescent Protein" \\
\hline $\mathrm{EmFi}$ & Embryonale Fibroblasten \\
\hline ESC & "Embryonic Stem Cell” \\
\hline ES-Zelle & Embryonale Stammzelle \\
\hline et al. & et alii \\
\hline EtOh & Ethanol \\
\hline FACS & "Fluorescence Activated Cell Sorting" \\
\hline FB & Fibroblasten \\
\hline FKS & Fetales Kälberserum \\
\hline$g$ & Gramm \\
\hline$\times g$ & Erdbeschleunigung $\left(9,81 \mathrm{~m} / \mathrm{s}^{2}\right)$ \\
\hline $\mathrm{h}$ & Stunde \\
\hline HBSS & Hank’s Balanced Salt Solution \\
\hline hCG & humanes Choriongonadotropin \\
\hline $\mathrm{HCl}$ & Chlorwasserstoff \\
\hline \multirow[t]{2}{*}{ HEPES } & N-2-Hydroxyethylpiperazin-N'-2- \\
\hline & Ethansulfonsäure \\
\hline $\mathrm{HLH}$ & "Helix- loop- Helix" \\
\hline $\mathrm{H}_{2} \mathrm{O}$ & Wasserstoffoxid \\
\hline HPRT & Hypoxanthin-Phosphoribosyl-Transferase 1 \\
\hline Hyg & Hygromycin \\
\hline ICSI & intrazytoplasmatische Spermieninjektion \\
\hline $\lg G$ & Immunglobulin G \\
\hline i.p. & intraperitoneale (Injektion) \\
\hline IPTG & Isopropyl- $\beta$-D-thiogalactopyranosid \\
\hline IU & international unit \\
\hline $\mathrm{kb}$ & Kilobase \\
\hline I & Liter \\
\hline LB & Luria- Bertani (Medium) \\
\hline LIF & Leukemia Inhibitory Factor \\
\hline
\end{tabular}




\begin{tabular}{ll} 
LSM & Laser- Scanning- Mikroskop \\
$\mathrm{LW}$ & Leerwert \\
$\mathrm{M}$ & Molar $(\mathrm{mol} / \mathrm{l})$ \\
$\mathrm{m}-$ & milli- $\left(1 \times 10^{-3}\right)$ \\
$\mathrm{maGSC}$ & "multipotent adult Germline Stem Cell" \\
$\mathrm{MCS}$ & "mutiple cloning site" \\
$\mathrm{MEF}$ & Mitose- inhibierte Maus- Fibroblasten \\
$\mathrm{MgCl}$ & Magnesiumchlorid \\
$\mathrm{min}$ & Minute \\
$\mathrm{MOPS}$ & $3-(\mathrm{N}-$ Morpholino)-Propansulfonsäure \\
$\mathrm{MPI}$ & Max-Planck-Institut \\
$\mathrm{mRNA}$ & messenger Ribonukleinsäure \\
$\mu-$ & mikro- $\left(10^{-6}\right)$ \\
$\mathrm{n}-$ & nano- $\left(10^{-9}\right)$ \\
$\mathrm{NaAc}$ & Natriumacetat \\
$\mathrm{NaCl}$ & Natriumchlorid \\
$\mathrm{NaHCO}{ }_{3}$ & Natriumhydrogencarbonat \\
$\mathrm{Na} \mathrm{HPO}_{4}$ & Dinatriumhydrogenphosphat \\
$\mathrm{NaH}{ }_{2} \mathrm{PO}_{4}$ & Natriumdihydrogenphosphat \\
$\mathrm{NaOH}_{\mathrm{NES}}$ & Natriumhydroxid \\
$\mathrm{NLS}$ & "nuclear export signals" \\
$\mathrm{Nr}$. & "nuclear localisation signal" \\
$\mathrm{ORF}$ & Nummer \\
$\mathrm{P} .$. & "Open Reading Frame" \\
$\mathrm{p}-$ & Passage \\
$\mathrm{Pa}$ & piko- $\left(1 \times 10^{-12}\right)$ \\
$\mathrm{PBS}$ & Pascal \\
\hline
\end{tabular}

PBS Phosphatgepufferte Salzlösung

PCR Polymerase- Kettenreaktion

PFA Paraformaldehyd

$\mathrm{pH} \quad \mathrm{pH}-$ Wert (negativ dekadischer Logarithmus der $\mathrm{H}^{+}$- lonenkonzentration) 
PMSG

RA

RNA

RNase

rpm

RT

RT-PCR

$\mathrm{S}$

S.

SDS

sec.

sek.

siRNA

SSC

SSC (-Puffer)

Stk.

Stra8

Tab.

Taq-

TBE

TC

TE

Tris

U

UK

UMG

üN

USA

UV

V

WT
Pregnant Mare's Serum Gonadotropin

Retinsäure

Ribonukleinsäure

Ribonuklease

Rotationen pro Minute

Raumtemperatur

Reverse Transkriptase- Polymerase-

Kettenreaktion

Sekunde

Seite

Natriumdodecylsulfat

Sekunde

sekundär

"Small interfering RNA"

spermatogoniale Stammzellen

"Standard Saline Citrat" (-Puffer)

Stück (Anzahl)

"Stimulated by retinoic acid gene 8"

Tabelle

Thermus aquaticus

Tris- Borat- EDTA (-Puffer)

Teratokarzinom

Tris- EDTA (-Puffer)

Tris- hydroxymethyl- aminomethan

Unit (Einheit der Enzymaktivität)

"United Kingdom"

Universitätsmedizin Göttingen

über Nacht

"United States of America"

Ultraviolett

Volt

Wildtyp 


$\begin{array}{ll}\text { w/v } & \text { Gewicht pro Volumen } \\ \text { www } & \text { "World Wide Web" } \\ \text { X-Gal } & 5 \text {-Brom-4-Chlor-3-Indoxyl- } \beta \text {-D-Galactopyranosid } \\ \text { z.T. } & \text { zum Teil }\end{array}$

Code der Nukleinsäuren

$\begin{array}{ll}A & \text { Adenosin } \\ C & \text { Cytosin } \\ G & \text { Guanin } \\ T & \text { Tymin } \\ U & \text { Uracil }\end{array}$




\section{Einleitung}

Stra8 (Stimulated by retinoic acid gene 8) ist ein testisspezifisches Gen, das in der prämeiotischen Phase der Spermatogenese exprimiert wird (OuladAbdelghani et al. 1996). Im Rahmen einer biologischen Doktorarbeit wurde in unserer Arbeitsgruppe eine transgene Maus generiert, die unter der Kontrolle des 1,4 kb- Stra8- Promotors EGFP (Enhanced Green Fluorescent Protein) exprimiert (Jaroszynski 2005). Über die EGFP- Fluoreszenz im Testis der transgenen Mäuse ist es möglich, die Stra8 exprimierenden Zellen der Spermatogenese zu identifizieren. Guan et al. (2006) nutzten diese Möglichkeit, um aus Testes dieser Mäuse Zellen der frühen Spermatogenese zu isolieren. Hierzu wurden die Stra8/EGFP- transgenen Mäuse zunächst mit Rosa 26-LacZ- transgenen Mäusen verpaart. In dieser transgenen Maus wird $\beta$-Gal unter der Kontrolle des Rosa26- Promotors ubiquitär exprimiert, womit eine spätere Detektion der Zellen über eine einfache LacZ- Färbung ermöglicht wird. Aus einer Testissuspension der entstandenen doppelt transgenen Mäuse wurden nun mittels EGFP- FACSortierung Stra8 exprimierende Zellen isoliert und unter verschiedenen Bedingungen kultiviert. Die Kultivierung dieser Zellen unter den Standard- ES- Zell- Bedingungen (mit Leukemia Inhibiting Factor und auf Mitose- inhibierten embryonalen Mausfibroblasten) brachte Kolonien hervor, die denen von embryonalen Stammzellen glichen. Weitere Untersuchungen zeigten, dass diese Zellen in vitro in der Lage sind, in Derivate aller drei Keimblätter zu differenzieren. In immundefizienten Mäusen führten sie zu Teratombildung, und nach Blastozysteninjektion bildeten sie Chimären. Auch konnte gezeigt werden, dass diese Zellen Pluripotenzgene exprimieren (Oct3/4, Nanog, Utf1, Esg1, Rex1). Die kultivierten Zellen haben somit ähnliche Eigenschaften wie embryonale Stammzellen (ESC) und werden "multipotent adult Germline Stem Cells" (maGSCs) genannt. Die Isolierung und Kultivierung pluripotenter Zellen aus den Testes der transgenen Mäuse warf die Frage auf, welche Rolle das Gen Stra8 in pluripotenten Zellen besitzt, und ob die Expression von Stra8 eventuell einen Einfluss auf die pluripotenten Eigenschaften der 
Zellen hat. Für diese Annahme spricht, dass Stra8 sowohl in embryonalen Stammzellen als auch in spermatogonialen Stammzelllinien (maGCSs) auch nach mehreren Passagen noch exprimiert wird (Nolte 2008). Auch die kürzlich von Tedesco et al. (2009) veröffentlichten Untersuchungen, in denen gezeigt wurde, dass es zu einem "shuttle" des STRA8- Proteins zwischen Zytoplasma und Nukleus kommt und STRA8 an DNA bindet, sprechen für eine eventuell regulatorische Funktion von Stra8 in pluripotenten Zellen.

Wie Tabelle 1 zeigt, sind bereits mehrere Keimzell- assoziierte Gene identifiziert, die Einfluss auf die pluripotenten Eigenschaften von Zellen haben.

Tabelle 1: Aufzählung von Keimzell- spezifischen Genen, die im Zusammenhang mit den pluripotenten Eigenschaften von Zellen stehen

\begin{tabular}{|l|l|}
\hline Keimzell- spezifische Gene & Referenz \\
\hline Oct4 & Pesce and Schöler 2001 \\
\hline Nanog & Chambers et al. 2003 \\
\hline Dppa2 & Maldonado-Saldivia et al. 2007 \\
\hline Dppa3 & Saitou et al. 2002 \\
\hline Dppa4 & Maldonado-Saldivia et al. 2007 \\
\hline Ifitm3 & Saitou et al. 2002 \\
\hline Kit & Horie et al. 1991 \\
\hline DAZIL & Clark AT et al. 2004 \\
\hline Akp2 & Chiquoine 1954 \\
\hline Sox2 & Western et al. 2005 \\
\hline Zfp206 & Wang et al. 2007(a+b) \\
\hline &
\end{tabular}

In der vorliegenden Arbeit soll die Rolle von Stra8 in pluripotenten Zellen genauer untersucht werden. Die von Wang et al. (2007a) veröffentlichten Untersuchungen über das testisspezifische Gen Zfp206 und seine Rolle in pluripotenten Zellen sollen als Grundlage dienen. Wang et al. (2007a) konnten zeigen, dass eine Expression von Zfp206 in Geweben von adulten Mäusen nur im Testis und in Präimplantationsembryonen nachzuweisen ist. 
Durch eine stabile Überexpression von Zfp206 in ES-Zellen wurde gezeigt, dass die Zellen eine geringere Tendenz haben unter Differenzierungsbedingungen (ohne LIF und Feeder Layer, mit Zugabe von Retinsäure) zu differenzieren als Wildtyp- ES- Zellen. Hingegen zeigten ESZellen, in denen Zfp206 durch siRNA herunterreguliert wurde, eine schnellere Differenzierung als unbehandelte Zellen. Untersuchungen des Expressionsmusters in den Zfp206 überexprimierenden Zellen zeigten, dass in diesen Zellen nicht nur Zfp206, sondern auch die Pluripotenzgene Oct4 und Nanog verstärkt exprimiert werden. Hingegen wurden die Gene Oct4 und Nanog beim Einsatz von Zfp206 siRNA herunter reguliert. Es kann somit davon ausgegangen werden, dass Zfp206 eine regulatorische Funktion auf die Pluripotenzgene Oct4 und Nanog hat.

Die bisher publizierten Untersuchungen über die Eigenschaften von Stra8 beschäftigen sich überwiegend mit einer eventuellen Rolle in der Meiose. So ist es Menke et al. (2003) gelungen, neben der schon bekannten Expression von Stra8 in frühen Phasen der Spermatogenese auch eine Stra8Expression in sich entwickelnden Ovarien in den Embryonalstadien 12,5 dpc (days post coitum) bis 14,5 dpc zu detektieren. Diese Ergebnisse wurden von Zhou et al. (2008a) teilweise bestätigt. Durch Mikroarray- Analysen zeigte diese Arbeitsgruppe, dass im Embryonalstadium 14,5 dpc eine Stra8Expression im Ovar zu detektieren ist, jedoch nicht in den Stadien 11,5 dpc und 12,5 dpc. Ein weiterer Hinweis dafür, dass Stra8 eine Rolle in der Meiose spielen könnte, ist die Tatsache, dass sowohl weibliche als auch männliche homozygote Stra8- Knock- out- Mäuse infertil sind und die Keimzellen einem Meiosearrest unterliegen (Baltus et al. 2006). 


\subsection{Ziele der vorliegenden Arbeit}

Folgende Themen werden in der vorliegenden Arbeit bearbeitet:

1. Stra8- Expression in Ovar und Testis post partum

2. Expressionsmuster in ES-Zelllinien und SSC-Zelllinien (maGSCs) auf RNA- und Proteinebene

3. Vergleich der Stra8- Expression in ES- Zellen unter verschiedenen Zellkultur- Bedingungen

4. Expression von Stra8 in verschiedenen Präimplantationsembryonen

5. Stra8 und seine Rolle in Bezug auf Pluripotenz. 


\section{Material und Methoden}

\subsection{Materialien}

\subsubsection{Chemikalien}

1 kb- DNA- Leiter

Invitrogen, Karlsruhe

Agar

Roth, Karlsruhe

Agarose

Peqlap, Erlangen

Ampicillin

Sigma, Deisenhofen

Ampuwa

Fresenius AG, Bad Homburg

$\beta$ - Mercaptoethanol

Serva, Heidelberg

Borsäure

Roth, Karlsruhe

BSA

Biomol, Hamburg

Chloroform

T.J. Baker, Deventer, Niederlande

Collagenase

Sigma, Deisenhofen

DH5a-kompetente- Zellen

Invitrogen, Karlsruhe

Diethylpyrocarbonat (DEPC)

Sigma, Deisendorf

Dimethylformamid

Roth, Karlsruhe

DMEM

PAN, Aidenbach

DMSO

Sigma, Deisenhofen

DNase

Sigma, Deisenhofen

dNTPs

Dithiothreitol (DTT)

Invitrogen, Karlsruhe

Applichem, Darmstadt

Ethylendiamintetraacetat (EDTA)

Sigma, Deisenhofen

Ethanol

T.J. Baker, Deventer, Niederlande

Ethidiumbromid

Roth, Karlsruhe

FKS

PAN, Aidenbach

Formaldehyd ( $\geq 37 \%$ )

Merck, Darmstadt

Formamid (deionisiert)

Sigma, Deisenhofen

Gelatine

Sigma, Deisenhofen

HBSS- Medium

Sigma, Deisenhofen

Hefeextrakt

Roth, Karlsruhe

IPTG

Biomol, Hamburg

Isopropanol

T.J. Baker, Deventer, Niederlande 
Lachsspermien- DNA

L- Glutamin

LIF

M2- Medium

Membran- Hybridisierungspuffer

Mitomycin C

Natriumchlorid

nicht- essentielle Aminosäuren

Orange G

Paraformaldehyd

PBS

Penicillin/ Streptomycin

Pepton

Phenol

Platinum- Taq-Polymerase

Proteinase $\mathrm{K}$

Radioaktiv markierte Reagenzien:

[ $\left.\alpha^{32} \mathrm{P}\right]-\mathrm{dCTP}$

Rapid- Hybridization- Puffer

Restriktionsenzyme

Retinsäure

Reverse- Transkriptase

RNA- Ladder

RNase- Inhibitor

SDS

SOC- Medium

Sodium- Pyruvat

TriReagent

Tris

Trypsin/ EDTA

Trypton

Tween20
Sigma-Aldrich Chemie, Taufkirchen

Gibco/ BRL, Eggenstein

Chemicon, Temecula, USA

Sigma, Deisenhofen

KPL medac, Wedel

Sigma, Deisenhofen

Applichem, Darmstadt

Gibco/BRL, Eggenstein

Sigma, Deisenhofen

Applichem, Darmstadt

Invitrogen, Karlsruhe

PAN, Aidenbach

Roth, Karlsruhe

Biomol, Hamburg

Invitrogen, Karlsruhe

Applichem, Darmstadt

Perkin, Elmer

Amersham, Freiburg

Invitrogen, Karlsruhe

Sigma, Deisenhofen

Invitrogen, Karlsruhe

Invitrogen, Karlsruhe

Boehringer, Mannheim

Serva, Heidelberg

Invitrogen, Karlsruhe

Gibco/BRL, Eggenstein

MRC, Cincinnati

Sigma, Deisenhofen

PAN, Aidenbach

Roth, Karlsruhe

Promega, Mannheim 
Vector Shield with DAPI

Vector Laboratories, Burlingame

X-Gal

Biomol, Hamburg

Xylol

Merck, Darmstadt

\subsubsection{Gebrauchswaren}

Gebrauchswaren, die nicht gesondert aufgeführt wurden, wurden von den Firmen Schütt bzw. Krannich, Göttingen, bezogen.

\subsubsection{Allgemeine Gebrauchswaren}

Blottingpapier GB-003

Glaswaren

Kühlzentrifugenbecher

Nitrocellulosefilter BA 85

Objektträger/ Deckgläschen

Objektträger Superfrost

PCR- Gefäße

Petrischalen

Pipettenspitzen mit Filter

Pipettenspitzen ohne Filter

Quarz- Küvetten

Reaktionsgefäße

Reaktionsgefäße (RNase- frei)

Röntgenfilme Hyperfilm ${ }^{\mathrm{TM}} \mathrm{MP}$

14- ml- Zentrifugenröhrchen
Schleicher \& Schüll, Dassel

Schott, Mainz

Nalgene, Rochester, USA

Schleicher \& Schüll, Dassel

Schütt, Göttingen

Menzel-Gläser, Braunschweig

Molecular BioProducts, San Diego, USA

Greiner, Nürtingen

Biozym, Hessisch Oldendorf

Eppendorf, Hamburg

Hellma, Mühlheim

Eppendorf, Hamburg

Brand, Wertheim

Amersham Pharmacia Biotech,

Freiburg

Corning, New York, USA

\subsubsection{Gebrauchswaren für die Zellkultur}

Auslaufpipetten

Falcon- Filter

Filtrationseinheit

Kryoröhrchen
Sarstedt, Nümbrecht

BD Biosciences, Heidelberg

Nalgene, Rochester, USA

Greiner, Nürtingen 
Kulturschalen $(6 \mathrm{~cm}$ und $10 \mathrm{~cm})$

Objektträger für die Zellkultur

Pasteurpipetten

Spritzen (5 ml und $10 \mathrm{ml}$ )

Sterilfilter

24- Well- Platte

6- Well- Platte

13- ml- Zentrifugenröhrchen

Zellkulturflaschen

Zellschaber

\subsubsection{Geräte}

Accu- Jet

Automated DNA- Sequencer

ABI 377

Brutschrank IR Autoflow

$\mathrm{CO}_{2}$ Water- Jacketed- Incubator

Fluoreszenzmikroskop BX60

Inversmikroskop IX81

Konvokalmikroskop

Lichtmikroskop

FACScan ${ }^{\mathrm{TM}}$ Durchflusszytometer

Mikrotom

Photometer

Primus Cycler

PTC-100 ${ }^{\mathrm{TM}}$ Peltier Thermal Cycler

Sterilbank HERAsafe

Thermomixer 5436

Zentrifuge Biofuge 13

Zentrifuge Hettich Universal

Zentrifuge Megafuge 1.OR
Nunc, Wiesbaden

BD Biosciences, Heidelberg

Brand, Wertheim

BD Biosciences, Heidelberg

Sartorius, Göttingen

Nunc, Wiesbaden

Nunc, Wiesbaden

Sarstedt, Nümbrecht

Greiner, Nürtingen oder Sarstedt,

Nümbrecht

Greiner, Nürtingen

Brand, Wertheim

Applied Biosystems, Foster City, USA

Sanyo, Tokyo, Japan

Olympus, Planegg

Olympus, Planegg

Olympus, Planegg

Zeiss, Göttingen

Becton- Dickinson, Heidelberg

Leica, St. Gallen, Schweiz

Eppendorf, Hamburg

MWG- Biotech, Ebersberg

MJ Research, BioRad

Heraeus, Hanau

Eppendorf, Hamburg

Heraeus, Osterode

Hettich, Tuttlingen

Heraeus, Osterode 
Zentrifuge J2-21

Beckmann, München

Zentrifuge 5415 D

Eppendorf, Hamburg

\subsubsection{Sterilisation}

Die Sterilisation von Lösungen erfolgte im Dampfdruckautoklaven für 20 min bei $121^{\circ} \mathrm{C}$ und $10^{5} \mathrm{~Pa}$ im oder durch Sterilfiltration (Porengröße: 0,2 $\mu \mathrm{m}$ ) bei hitzeempfindlichen Lösungen. Gebrauchswaren wurden autoklaviert oder für $8-12$ h bei $180^{\circ} \mathrm{C}$ hitzesterilisiert.

\subsubsection{Puffer und Lösungen}

Alle Lösungen, die für den routinemäßigen Laborbetrieb notwendig waren, wurden nach Sambrook et al. (1989) angesetzt. Entsprechend den Erfordernissen wurden die Chemikalien in deionisiertem $\left(\mathrm{dH}_{2} \mathrm{O}\right)$, in vollentsalztem (Millipore), in bidestilliertem Wasser $\left(\mathrm{dd}_{2} \mathrm{O}\right)$ oder in Ampuwa gelöst. Die Lösungen wurden je nach Bedarf dampfdrucksterilisiert, steril filtriert, frisch angesetzt oder aliquotiert und bei $-20^{\circ} \mathrm{C}$ bzw. $4^{\circ} \mathrm{C}$ aufbewahrt.

Die Puffer für Enzyme und für gebrauchsfertige Kits wurden, wie vom Hersteller geliefert, angewendet. Aus den Beipackzetteln ist die Zusammensetzung der Puffer ersichtlich und wird hier nicht weiter aufgeführt.

Blockierlösung

$0,2 \%$ BSA

$0,1 \%$ Tween20

in PBS

DNA- Probenpuffer

$15 \%$ Ficoll 400

200 mM EDTA

$1 \%$ Orange G

$\begin{array}{ll}\text { dNTP- Lösung (25 mM) } & 100 \text { mM dATP } \\ 100 \text { mM dCTP } \\ 100 \text { mM dGTP } \\ 100 \text { mM dTTP }\end{array}$


IPTG

Lysispuffer für Gewebe

Lysispuffer für Zellen

10x MOPS- Puffer (pH 7.0)

Paraformaldehydlösung (4\%ig)

$\operatorname{SSC}(20 x)$

Stop- Mix (5x)

TE- Puffer
$100 \mathrm{mM}$ in $\mathrm{H}_{2} \mathrm{O}$

$50 \mathrm{mM}$ Tris / $\mathrm{HCl}(\mathrm{pH} \mathrm{8,0)}$

100 mM EDTA

$0,5 \%$ SDS

$1 \mathrm{M}$ Tris / $\mathrm{HCl}(\mathrm{pH} 8,5)$

0,5 M EDTA

$10 \%$ SDS

$5 \mathrm{M} \mathrm{NaCl}$

$10 \mathrm{mg} / \mathrm{ml}$ Proteinase $\mathrm{K}$

$0.2 \mathrm{M}$ MOPS

$50 \mathrm{mM} \mathrm{NaAc}$

$0.5 \mathrm{M}$ EDTA

in DEPC- $\mathrm{H}_{2} \mathrm{O}$

$8 \mathrm{~g}$ PFA

$200 \mu$ l Tween-20

$180 \mathrm{ml}$ DEPC- $\mathrm{H}_{2} \mathrm{O}$

$20 \mathrm{ml} 10 x$ PBS

$3 \mathrm{M} \mathrm{NaCl}$

0,3 M Tri- Natriumcitrat ( $\mathrm{pH} 7.0$ )

$15 \%$ Ficoll 400

200 mM EDTA

10\% Glycerin

$0,1 \%$ Orange $G$

$1 \mathrm{mM}$ EDTA

$10 \mathrm{mM}$ Tris/HCl (pH 8.0) 
TBE (5x)

0,45 M Tris / HCl

0,45 M Borsäure

10 mM EDTA (pH 8,5)

Waschlösung I

2x SSC

$0,2 \times$ SSC

Waschlösung II

$0,1 \%$ SDS

in $0,2 \times S S C$

X- Gal- Lösung

2\% X-Gal in Dimethylformamid

\subsubsection{Gebrauchsfertige Reaktionssysteme}

Dyenamic ET- Terminator Mix

EndoFree® Plasmid Maxi Kit

Montage ${ }^{\mathrm{TM}}$ PCR Centrifugal

Filter Devices System

pGEM®T- Easy Vector System I

Immolase- Taq-

DNA- Polymerase- System

PLATINUM® Taq-

DNA- Polymerase- System

QIAquick® Gel Extraktion Kit

QIAshredder ${ }^{\mathrm{TM}}$

Rediprime $^{\mathrm{TM}}$ II Random Prime Labelling System

Rneasy® Mini Kit

SUPERSCRIPTTM II RNaseH Reverse- Transkriptase

TriReagent ${ }^{\mathrm{TM}}$
Amersham Biosciences, Freiburg

Qiagen, Hilden

Millipore Corporation, Bedford

Promega, Wisconsin, USA

Bioline, Mannheim

Gibco, BRL, Eggenstein

Qiagen, Hilden

Qiagen, Hilden

Amersham Biosciences, Freiburg

Qiagen, Hilden

Invitrogen, Groningen, Niederlande

Sigma, Deisenhofen 


\subsubsection{Vektoren}

pGEM-T Easy

pCMV myc

pTK hyg
Promega, Madison, USA

Clontech, Franklin Lakes, USA

Clontech, Franklin Lakes, USA

\subsubsection{Bakterien}

Escherichia coli

DH5a (Hanahan 1983)

Invitrogen, Groningen, Niederlande

\subsubsection{Medien für die Bakterienkultur}

Die Nährmedien für die Bakterienkulturen wurden mit einfach destilliertem Wasser angesetzt. Danach wurden sie autoklaviert und bei $4^{\circ} \mathrm{C}$ aufbewahrt. Benötigte Zusätze wurden nach dem Autoklavieren bei einer Temperatur von $50-60^{\circ} \mathrm{C}$ hinzugefügt. Agarplatten enthielten 1,5\% (w/v) Agarose.

LB- Medium ( $\mathrm{pH} 7,5)$

$$
\begin{aligned}
& \text { Pepton } 5 \mathrm{~g} \\
& \text { Hefeextrakt 2,5 g } \\
& \mathrm{NaCl} 5 \mathrm{~g} \\
& 500 \mathrm{ml} \mathrm{H}_{2} \mathrm{O}
\end{aligned}
$$

Zusätze zur Selektion

Ampicillin (0,1 mg / ml)

Zusätze für Oja- Platten

$$
100 \mu \mathrm{M} \text { IPTG }
$$

$4 \% \times-G a l$

Stammlösungen

$$
\begin{aligned}
& 100 \mathrm{mg} / \mathrm{ml} \text { Ampicillin in } \mathrm{H}_{2} \mathrm{O} \\
& 0.2 \mathrm{~g} / \mathrm{ml} \text { IPTG in } \mathrm{H}_{2} \mathrm{O} \\
& 8 \% \mathrm{X} \text {-Gal in Dimethylformamid }
\end{aligned}
$$

Die Lösungen wurden steril filtriert. Die Lagerung erfolgte bei $-20^{\circ} \mathrm{C}$. Alle Zusätze, wie Antibiotika, IPTG und X-Gal wurden nach dem Autoklavieren 
den abgekühlten Medien (ca. $50^{\circ} \mathrm{C}$ ) hinzugegeben. Flüssigmedien und Platten wurden bei $4^{\circ} \mathrm{C}$ gelagert.

\subsubsection{Mausstämme}

Die für diese Arbeit verwendeten Mäuse stammten aus Beständen des Institutes für Humangenetik Göttingen. Sie wurden mit einem zwölfstündigen Hell- Dunkel- Rhythmus bei $22^{\circ} \mathrm{C}$ und $55 \pm 5 \%$ relativer Luftfeuchtigkeit gehalten. Von der Firma ssniff- Spezialdiäten (Soest) wurde das Tierfutter bezogen. Futter und Wasser standen den Mäusen frei zur Verfügung.

\subsubsection{Eukaryotische Zelllinien}

\begin{tabular}{|l|l|l|}
\hline Zelllinie & isoliert aus & \multicolumn{1}{|c|}{ Referenz } \\
\hline ES RI & Embryonale Stammzellen & Nagy et al. 1993 \\
\hline SSC129SV & Spermatogoniale Stammzellen & Nolte 2008 \\
\hline ES FVB & Embryonale Stammzellen & Nolte 2008 \\
\hline SSC FVB & Spermatogoniale Stammzellen & Nolte 2008 \\
\hline ES C57BI & Embryonale Stammzellen & Nolte 2008 \\
\hline SSC C57BI & Spermatogoniale Stammzellen & Nolte 2008 \\
\hline ES dt Stra8 & Embryonale Stammzellen & Nolte 2008 \\
\hline SSC15Nr12 & Spermatogoniale Stammzellen & Nolte 2008 \\
\hline MEF & Embryonale Fibroblasten & Adham et al. 1997 \\
\hline
\end{tabular}

\subsubsection{Medien für die Zellkultur}

Die für die Anzucht eukaryotischer Zellen benötigen Medien und Zusätze wurden als sterile Lösungen bezogen (Gibco BRL, Eggenstein; PAN, Aidenbach).

\section{ESC- Medium}

\section{DMEM}

0,1 mM nicht- essentielle Aminosäuren

$1 \mathrm{mM}$ Natriumpyruvat

$1 \mu \mathrm{M} \beta$-Mercaptoethanol

2 mM L- Glutamin 
$1 \mathrm{mM}$ Penicillin/ Streptomycin

$20 \%$ FKS

(1 $000 \mathrm{U} / \mathrm{ml} \mathrm{LIF})$

FB- Medium

M2- Medium
DMEM

2 mM L-Glutamin

$1 \mathrm{mM}$ Penicillin / Streptomycin

$10 \%$ FKS

$5 \mathrm{ml} 10 \times$ Hanks

$1,25 \mathrm{ml} 40 \times$ HEPES

$165 \mu \mathrm{l} 300 \times$ Na-Pyruvat

$0,25 \mathrm{ml} 1 \mathrm{M} \mathrm{NaOH}$

$0,5 \mathrm{ml}$ Penicillin $(6 \mathrm{mg} / \mathrm{ml})$

Streptomycin $(5 \mathrm{mg} / \mathrm{ml})$

$43 \mathrm{ml}$ Ampuwa

0,2 g BSA

Folgende Einfriermedien wurden zur Langzeitlagerung der Zellen in flüssigem Stickstoff verwendet:

Zellen ohne "Feeder Layer"

(MEF- Zellen ("Feeder Layer"

siehe 2.2.6))

Zellen mit "Feeder Layer"

(ESC- bzw. SSC- Zellen)
$30 \%$ FB- Medium

$20 \%$ DMSO

$50 \%$ FKS

$30 \%$ ESC- Medium

$20 \%$ DMSO

$50 \%$ FKS

Die Einfriermedien wurden angesetzt, steril filtriert und anschließend bei $20^{\circ} \mathrm{C}$ gelagert. 


\subsubsection{Antikörper}

Primärantikörper:

anti- STRA8, polyklonaler Antikörper, IgG, Kaninchen (Abcam, Cambridge, UK)

Sekundärantikörper:

anti- Kaninchen IgG, Cy3 konjugiert, Ziege

(Sigma- Aldrich, Deisenhofen)

\subsubsection{Sonden}

- Stra8

Als Stra8- Sonde wurde der 1,2 kb große ORF von Stra8 verwendet. Dieser wurde mit den Primern mStra8-ORF-Not1-F und mStra8-ORF-Not1-R amplifiziert, isoliert, in pGEM-T Easy kloniert, sequenziert und ausgeschnitten.

- $\beta$ - Actin Clontech, Heidelberg

\subsubsection{Oligonukleotide}

Alle Primer, die für die Experimente eingesetzt wurden, stammten von der Firma Operon, Köln. Mit Ampuwa wurde eine Konzentration von 100 यM (100 $\mathrm{pmol} / \mu \mathrm{l}$ ) eingestellt und bei $-20^{\circ} \mathrm{C}$ als Stock gelagert. Die Konzentration der eingesetzten Primer lag bei $10 \mathrm{pmol} / \mu \mathrm{l}$.

2.1.13.1 Primer für RT- PCR $(\mathrm{m}=$ mouse):

- $\mathrm{mHPRT}-\mathrm{F} 1$ :

mHPRT-R1:

- mStra8-F1:

mStra8-R1:

- mZfp206-F2:

mZfp206-R2:
5' - CGTCGTGATTAGCGATGATG - 3'

5' - TATGTCCCCCGTTGACTGAT - 3'

5' - TCACAGCCTCAAAGTGGCAGG - 3'

5' - GCAACAGAGTGGAGGAGGAGT - 3'

5' - CAGTTCAAATTGGCAATGAGCC - 3'

5' - GGTCTCCTGCCCTCAGTTTGCG - 3' 


\subsubsection{Primer für die Sequenzierung}

- ORF-Stra8-Seq-F1:

ORF-Stra8-Seq-R1:

- ORF-Stra8-Seq-F2:

ORF-Stra8-Seq-R2:

- ORF-Stra8-Seq-F3:

ORF-Stra8-Seq-R3:

- Sp6:

T7:

5' - AACCAACCCAGTGATGATGGG - 3'

5' - CCCATCATCACTGGGTTGGTT - 3'

5' - AGAGAGGTAGAGGAGTACCAG - 3'

5' - CTGGTACTCCTCTACCTCTCT - 3 '

5' - ATGTTGCTGAAGTGCCTGGAG - 3'

5' - CTCCAGGCACTTCAGCAACAT - 3'

5' - TTAGGTGACACTATAGAATACTCAA

GC - 3'

5' - AATACGACTCACTATAGGGCGAATT

$\mathrm{GG}-3^{\prime}$

\subsubsection{Andere Primer}

- Stra8/EGFP-F5:

Stra8/EGFP-R3:

- mStra8-ORF-Not I-F:

- mStra8-ORF-Not I-R:
5' - CGTAGTGTGCCAAACTAGTGTGG - 3'

5' - CAGGGTCAGCCTGCCGTAGGTGG - 3'

5' - ACCGCGGCCGCAGGTATGGCCACCCC

TGGAGAAGGCAACCAACCCAGT - 3'

5' - TTGCCGCCGCCTACCACCTTACAGATC

GTCAAAGGTCTCCAGGCACTT- 3'

\subsubsection{Molekulargewichtsstandard}

DNA- Längenstandard $(1 \mu \mathrm{g} / \mu \mathrm{l})$ : $1 \mathrm{~kb}$ - Leiter $(0,12$ - 12,2 kb)

Der DNA- Längenstandard wurde nach Herstellerangaben verdünnt und DNA- Probenpuffer hinzugefügt.

\subsubsection{Datenbanken}

Nukleotidsequenzen wurden mit den Sequenzdatenbanken EMBL (http://www.ebi.ac.uk) und GenBank (http://www.ncbi.nlm.nih.gov) mit Hilfe des BLAST- Programms (Altschul et al. 1990) analysiert. 


\subsection{Zellbiologische Arbeitsmethoden}

\subsubsection{Kultivierung von eukaryotischen Zellen}

Die verwendeten Zellen, welche ausschließlich adhärent wachsen, wurden im entsprechenden Medium bei $37^{\circ} \mathrm{C}$ kultiviert und zur Einstellung eines günstigen pH-Wertes (alle Medien enthielten $\mathrm{NaHCO}_{3}$ ) mit $5 \% \mathrm{CO}_{2}$ begast. Kurz vor Erreichen einer 100\%igen Konfluenz wurden die Zellen passagiert.

\subsubsection{Kultivierung von murinen embryonalen Stammzellinien (ES- Zellen)}

Embryonale Stammzellen sind aus der inneren Zellmasse von Blastozysten gewonnene pluripotente Zellen, die in der Lage sind, in Zellen aller drei Keimblätter zu differenzieren (Beddington und Robertson 1989). Um eine Ausdifferenzierung von ES-Zellen zu verhindern, werden diese auf Mitoseinhibierten Maus- Fibroblasten (Feederzellen) ausplattiert und dem ESMedium das Zytokin LIF (Leukemia Inhibitory Factor) zugegeben.

\subsubsection{Kultivierung von "multipotent adult Germline Stem Cells" (maGSCs)}

Spermatogoniale Stammzelllinien werden aus dem Hoden adulter Mäuse generiert, indem man durch bestimmte Kulturbedingungen die spermatogonialen Stammzellen (SSCs) reprogrammiert. Die so erhaltenen SSC- Zelllinien (auch maGSCs genannt; Guan et al. 2006) besitzen die gleichen Eigenschaften wie ES- Zellen und sind damit als pluripotent anzusehen (z.B. Zovoilis et al. 2008; Zechner et al. 2009; Dressel et al. 2009; Dihazi et al. 2009; Dressel et al. 2010). Auch die Kultur der SSC- Zelllinien erfolgt analog zu ES- Zellen (2.2.1.1).

\subsubsection{Kultivierung von murinen embryonalen Fibroblasten}

Für die Routinekultur der maGSC- und ES- Zellen wurden mitotisch inaktivierte embryonale Fibroblasten (MEFs) verwendet, die einen sogenannten "Feeder- layer" bilden. Um die mitotische Teilung der Zellen zu verhindern, erfolgt eine Behandlung mit dem Spindelgift Mitomycin C (Martin 
und Evans 1975). Anschließend werden die Fibroblasten in einer gleichmäßigen Zellschicht plattiert und die anderen Zellen darauf ausgesät.

\subsubsection{Isolation von murinen embryonalen Fibroblasten}

Zur Isolation der embryonalen Fibroblasten wurden 14,5 Tage alte MausEmbryonen (errechnet nach Vaginal Plug- Check) isoliert und in PBS gewaschen. Die Abdomina der Embryonen wurden zur Entnahme der inneren Organe eröffnet. Die Extremitäten und Köpfe der Embryonen wurden abgetrennt und verworfen. Die ausgeräumten Rümpfe wurden dann zerkleinert und in einen Kolben mit Glaskügelchen überführt. Die Suspension wurde nach Zugabe von $20 \mathrm{ml}$ Trypsin/EDTA und $1 \mathrm{ml}$ DNase $30 \mathrm{~min}$ bei $37^{\circ} \mathrm{C}$ unter Rühren inkubiert. Anschließend wurde die Zellsuspension $10 \mathrm{~min}$ bei $270 \times$ g abzentrifugiert, der Überstand verworfen und das Pellet in FBKulturmedium resuspendiert sowie in geeignete Kulturgefäße überführt. Um nicht adhärente Zellen zu entfernen, wurde etwa $24 \mathrm{~h}$ später das Kulturmedium gewechselt.

\subsubsection{Auftauen und Einfrieren von eukaryotischen Zellen}

Um Zellen zu kryokonservieren, wurde eine konfluent bewachsene Platte mit PBS gewaschen und trypsiniert. Durch Zugabe des in dem entsprechenden Kulturmedium enthaltenen FKS wurde das Trypsin wieder inaktiviert. Anschließend wurden die Zellen 5 min bei $270 \times$ g zentrifugiert. Nach Abnahme des Überstandes wurde das Pellet in $500 \mu \mathrm{l}$ Kulturmedium resuspendiert und in ein mit $500 \mu \mathrm{l}$ Gefriermedium gefültes Kryoröhrchen überführt. Nach vorsichtigem Mischen wurden die Zellen langsam eingefroren.

Da das Auftauen von eingefrorenen Zellen rasch erfolgen muss, wurden diese in einem $37{ }^{\circ} \mathrm{C}$ warmen Wasserbad aufgetaut. Zur schnellen Inaktivierung des DMSO- enthaltenden Gefriermediums wurden die Zellen anschließend in möglichst kurzer Zeit in einer größeren Menge Kulturmedium aufgenommen und für $5 \mathrm{~min}$ bei $270 \mathrm{xg}$ zentrifugiert. Nach Abnahme des Überstandes wurde das übrig gebliebene Pellet in der für das Ausplattieren 
benötigten Menge Kulturmedium resuspendiert und in ein Kulturgefäß überführt.

\subsubsection{Passagieren von eukaryotischen Zellen}

Für das Passagieren der kultivierten Zellen wurden die konfluent bewachsenen Platten zunächst mit PBS gewaschen. Je nach Größe des Kulturgefäßes wurden danach 1-5 ml Trypsin hinzugefügt. Unter dem Lichtmikroskop wurde nach circa 5 - minütiger Inkubation bei $37^{\circ} \mathrm{C}$ das Ablösen der Zellen beurteilt. Hatten sich die Zellen vom Kulturgefäß gelöst, wurde zur Inaktivierung des Trypsins das gleiche Volumen (1-5 ml) des FKSenthaltenden Kulturmediums zugegeben und gut resuspendiert. Nun wurden die Zellen für $5 \mathrm{~min}$ bei $270 \times \mathrm{g}$ abzentrifugiert und nach Verwerfen des Überstandes das Zellpellet in entsprechender Menge (2-10 ml) Kulturmedium aufgenommen und anschließend in geeigneten Kulturgefäßen ausplattiert. Zur Entfernung der nicht adhärenten Zellen erfolgte ein Mediumwechsel etwa 24 h später.

\subsubsection{Gelatine- Behandlung von Kulturgefäßen}

Abhängig von der Kulturgefäßgröße wurden zur Beschichtung etwa 1-10 ml sterile $0,1 \%$ ige Gelatine genutzt. Vor der weiteren Verwendung wurden die gelatinebeschichteten Kulturgefäße für mindestens $2 \mathrm{~h}$ bei $37^{\circ} \mathrm{C}, 5 \% \mathrm{CO}_{2}$, inkubiert und die überstehende Gelatine entfernt.

\subsubsection{Mitomycin- Behandlung von embryonalen Fibroblasten}

Zur Mitomycin- Behandlung von embryonalen Fibroblasten wurde Mitomycin $\mathrm{C}$ in einer Endkonzentration von $10 \mu \mathrm{g} / \mathrm{ml}$ eingesetzt. Dieses wurde zu einer mit embryonalen Fibroblasten konfluent bewachsenen Platte hinzugegeben. Nach etwa dreistündiger Inkubation bei $37^{\circ} \mathrm{C}, 5 \% \quad \mathrm{CO}_{2}$, wurden die Fibroblasten zweimal mit PBS gewaschen, trypsiniert und in Gelatinebeschichteten Kulturgefäßen ausplattiert (Fibroblasten, die mit Mitomycin behandelt wurden, können nicht mehr anwachsen, sie werden nur durch die Gelatine am Boden des Kulturgefäßes fixiert). 


\subsubsection{Induktion von eukaryotischen Zellen mit Retinsäure}

Die hoch wirksame aktive Form des Vitamin A, Retinsäure, beeinflusst die Proliferation und Differenzierung von Zellen.

Für die Induktion der Zellen zur Differenzierung wurde $10^{-6} \mathrm{M}$ Retinsäure eingesetzt und die Zellen für $24 \mathrm{~h}$ bis zu 15 Tagen inkubiert. Nach dem Mediumwechsel wurde dem Kulturmedium die Retinsäure direkt aus der Stocklösung $\left(10^{-3} \mathrm{M}\right)$ beigemengt.

\subsubsection{Herstellung einer testikulären Zellsuspension}

Die frisch isolierten Testes wurden zunächst in PBS gewaschen und in Kollagenase (1 mg / ml in HBSS) gegeben. Anschließend wurde die Tunica albuginea entfernt, die Tubuli seminiferi mechanisch zerkleinert und für 20 min bei $37^{\circ} \mathrm{C}$ inkubiert. Die Suspension wurde in HBSS- Medium gewaschen und für 5 min bei $270 \times \mathrm{g}$ abzentrifugiert. Dieser Vorgang wurde dreimal wiederholt. Danach erfolgte die Aufnahme des Pellets in $1 \mathrm{M}$ EDTA mit $0,25 \%$ Trypsin. Nach 5 - minütiger Inkubation bei $37^{\circ} \mathrm{C}$ wurden $20 \%$ des Gesamtvolumens an FKS zugegeben um die Reaktion zu stoppen. Die Suspension wurde zur Entfernung größerer Stücke durch Falcon- Filter mit $70 \mu \mathrm{m}$ Porengröße filtriert. Abschließend wurde das Filtrat 5 min bei $270 \times \mathrm{g}$ zentrifugiert und das Pellet in $100 \mu$ l PBS aufgenommen.

\subsubsection{FACS- Sortierung}

Die FACS- Sortierung ermöglicht die Identifizierung bestimmter Zelltypen aufgrund ihrer Größe, Granularität, oder Fluoreszenzen. Bei der vorliegenden Arbeit erfolgte die Sortierung mittels der EGFP- Expression. EGFPexprimierende Zellen exzitieren Fluoreszenzlicht bei $510 \mathrm{~nm}$.

Die zu sortierende Zellsuspension wurde vor der Messung zunächst mit PBS gewaschen, trypsiniert, abzentrifugiert und dann erneut mit PBS gewaschen. Anschließend erfolgte die Sortierung der Zellen im Durchflusszytometer. Als Negativkontrolle dienten nicht- EGFP- exprimierende Zellen. Nach der Sortierung wurden die EGFP- positiven Zellen abzentrifugiert. Sie wurden 
mit PBS gewaschen und zur Ausplattierung in ein passendes Kulturgefäß mit der entsprechenden Menge Kulturmedium aufgenommen.

\subsection{Histologische Arbeitsmethoden}

\subsubsection{Fixierung von Zellen und Geweben}

\subsubsection{Fixierung von Zellen mit Paraformaldehyd}

Für die Fixierung wurden die Zellen auf Zellkulturobjektträger mit zwei Kammern überführt und bis zur benötigten Konfluenz bei $37^{\circ} \mathrm{C}$ und $5 \% \mathrm{CO}_{2}$ inkubiert. Vor der eigentlichen Fixierung wurden die Zellen dreimal mit PBS gewaschen und dann 15 min mit 4\%igem Paraformaldehyd bei $4^{\circ} \mathrm{C}$ inkubiert. Vor der jeweiligen Untersuchung der fixierten Zellen wurden diese erneut dreimal mit PBS gewaschen.

\subsubsection{Fixierung von Organen und Geweben}

Die Organe wurden in Paraformaldehyd gelegt und für zwei Tage bei $4^{\circ} \mathrm{C}$ geschüttelt. Anschließend wurden sie in $70 \% \mathrm{EtOH}$ gelegt und üN unter Schütteln gewaschen. Zur Entwässerung wurden die Organe nun in eine aufsteigende Ethanolreine (1x $15 \mathrm{~min} 70 \% \mathrm{EtOH}, 3 \times 20 \mathrm{~min} 80 \% \mathrm{EtOH}, 4 x$ 30 min 90\% EtOH, 4x 30 min 96\% EtOH, 5x 20 min 100\% EtOH) gelegt und üN in Isopropanol gegeben und geschüttelt. Am nächsten Tag wurden die Gewebe für jeweils $30 \mathrm{~min}$ in verschiedenen Isopropanol- Xylol- Gemischen (75:25, 50:50, 25:75) inkubiert, nachfolgend in 100\% Xylol überführt und üN geschüttelt. Die Gewebe wurden in Paraffin eingebettet und zur Übertragung auf die Objektträger mit dem Mikrotom in $5 \mu \mathrm{m}$ dünne Schnitte geschnitten.

\subsubsection{Färbung von Zellen und Gewebeschnitten}

\subsubsection{Immunzytochemische Färbung von eukaryotischen Zellen}

Die in Paraformaldehyd fixierten Zellen wurden zur Blockierung der unspezifischen Antikörperbindungsstellen mit $1 \mathrm{ml}$ Blockierlösung je Kammer versetzt und 1-4 $\mathrm{h}$ bei RT inkubiert. Nach dem Blocken wurde der primäre Antikörper in einer 1:200 Verdünnung in PBS auf die Zellen gegeben und in eine Feuchtkammer bei $4{ }^{\circ} \mathrm{C}$ üN inkubiert. Die dort herrschende Feuchtigkeit 
verhindert die Austrocknung der Zellen. Am nächsten Tag erfolgte die Abnahme der primären Antikörper, anschließend wurden die Zellen 3x mit PBS gewaschen. Der sekundäre Antikörper wurde in einer 1:500Verdünnung in PBS zu den Zellen gegeben und in der Feuchtkammer für 2-3 $\mathrm{h}$ bei $4^{\circ} \mathrm{C}$ inkubiert. Nach erneutem Waschen mit PBS wurden die Zellen mit DAPI-haltigem VectaShield versehen, mit einem Deckgläschen eingedeckelt und dieser mit Nagellack versiegelt. Die Objektträger wurden bei $-20^{\circ} \mathrm{C}$ aufbewahrt.

\subsubsection{Immunhistochemische Färbung von Gewebeschnitten}

Für die immunhistochemische Färbung von Gewebeschnitten mussten diese zunächst rehydriert werden. Hierfür wurden die Schnitte zunächst zur Entfernung des Paraffins dreimal für 3 min in 100\% Xylol gegeben. Anschließend wurden die Schnitte in einer absteigenden Ethanolreihe (je 2 $\min 100 \%, 96 \%, 90 \%, 80 \%, 70 \%, 50 \% \mathrm{EtOH})$ gewaschen und in $\mathrm{dH}_{2} \mathrm{O}$ gegeben. Die immunozytochemische Färbung der Gewebe wurde nach der Rehydrierung wie bei den eukaryotischen Zellen vorgenommen.

\subsection{Molekularbiologische Arbeitsmethoden}

Die Durchführung der molekularbiologischen Methoden erfolgte nach den Standardprotokollen von Sambrook et al. (1989).

\subsubsection{Klonierung von DNA- Fragmenten}

\subsubsection{Spaltung von DNA durch Restriktionsendonukleasen}

Die Spaltung der DNA wurde mithilfe von Restriktionsenzymen verschiedener Hersteller in einem Volumen von 10 oder $20 \mu$ bei enzymspezifischer Temperatur für 45 bis 150 min durchgeführt. Von dem benötigten Enzym wurden standardmäßig $10 \mathrm{U}$ pro $\mu \mathrm{g}$ eingesetzt und die vom Hersteller angegebene Menge des optimalen Puffers hinzugefügt. Die "Insert"Isolierung erfolgte unter Verwendung von $10 \mu \mathrm{g}$ Plasmid- DNA mit $100 \mathrm{U}$

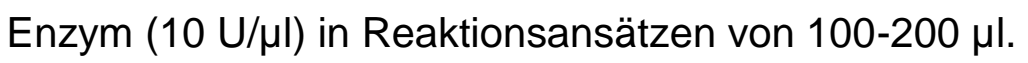


Für die gleichzeitige restriktionsenzymatische Spaltung mit zwei unterschiedlichen Enzymen wurde, soweit möglich, ein mit beiden Enzymen kompatibler Puffer eingesetzt. Zur Verhinderung von unspezifischen Reaktionen der Restriktionsenzyme wurde dem Restriktionsansatz $1 \mu \mathrm{g}$ BSA (10 mg/ml) zugegeben. Zur Vollständigkeitskontrolle des Verdaus wurde eine Agarosegelelektrophorese (siehe auch 2.4.5.1) mit einem Aliquot durchgeführt.

\subsubsection{Dephosphorylierung von Plasmid- Vektoren}

Die mittels Restriktionsendonukleasen linearisierten Plasmid- Vektoren wurden an ihren 5'- Phosphatgruppen hydrolysiert, um eine Rezirkulation unter Ligationsbedingungen zu verhindern. Zur Hydrolisierung der 5`Phosphatgruppen wurden zu 16,5 $\mu$ linearisiertem Plasmid 1,5 $\mu \mathrm{l}$ Antarktische- Phosphatase und $2 \mu$ Antarktische- Phosphatase- Puffer gegeben. Der $20 \mu \mathrm{l}$ Ansatz wurde für $15 \mathrm{~min}$ bei $37^{\circ} \mathrm{C}$ inkubiert. Zur Inaktivierung der Antarktischen- Phosphatase wurde der Ansatz anschließend $5 \mathrm{~min}$ bei $65^{\circ} \mathrm{C}$ erhitzt.

\subsubsection{Ligation von PCR- Produkten in pGEM-T Easy}

Die PCR- Produkte wurden mittels des pGEM-T Easy Vektorsystems (Promega) kloniert. Durch pGEM-T Easy können aufgereinigte PCRProdukte in den im System enthaltenen linearisierten Vektor integriert werden. Möglich ist dies durch den artifiziellen 3'- Thyminüberhang des Vektors, der komplementär zum 3'- Adeninüberhang der PCR- Produkte ist, den die meisten DNA- Polymerasen erzeugen (Clark JM 1988).

Die Ligation erfolgte in einem $10 \mu$ Ansatz. Hierzu wurden 50 ng des Vektors in drei- bis fünffachem molarem Überschuss mit dem aus dem Agarosegel isolierten Insert gegeben und mit $1 \mu \mathrm{l}$ T4-DNA-Ligase $(5 \mathrm{U} / \mu \mathrm{l})$ und $5 \mu \mathrm{l} 2 \mathrm{x}$ Ligasepuffer gemischt. Der Ansatz wurde üN bei $16^{\circ} \mathrm{C}$ inkubiert. 


\subsubsection{Ligation von PCR- amplifizierten DNA- Fragmenten}

Die Restriktionsschnittstellen der geschnittenen und aufgereinigten DNAFragmente waren komplementär $\mathrm{zu}$ denen des linearisierten und dephosphorylierten Plasmid- Vektors und konnten so direkt ligiert werden. In einen $10 \mu \mathrm{l}$ Ansatz wurden Vektor und Insert im Verhältnis eins zu zwei zu $1 \mu \mathrm{l}$ 10x Ligasepuffer gegeben. Zunächst wurde der Ansatz für 5 min bei $65^{\circ} \mathrm{C}$ erhitzt und anschließend 5 min auf Eis abgekühlt bevor $1 \mu \mathrm{l}$ T4-DNA-

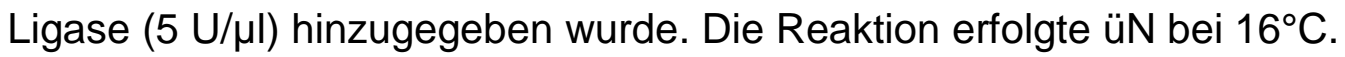

\subsubsection{Transformation kompetenter Escherichia- coli- Zellen mittels Hitzeschock}

$50 \mu \mathrm{l}$ einer Escherichia- coli- DH5a- Suspension wurden auf Eis langsame aufgetaut. Die Bakterien wurden anschließend vorsichtig gemischt und $2 \mu \mathrm{l}$ des zu transformierenden Vektors zugegeben. Anschließend erfolgte eine 20 minütige Inkubation des Ansatzes auf Eis. Um die Bakterien zu stimulieren, die DNA aufzunehmen, wurden sie einem Hitzeschock für 1 min bei $42^{\circ} \mathrm{C}$ ausgesetzt. Der Ansatz wurde danach für $5 \mathrm{~min}$ auf Eis gegeben. Nach Zugabe von $950 \mu \mathrm{l} \mathrm{SOC}$ - Medium wurde für $1 \mathrm{~h}$ bei $37^{\circ} \mathrm{C}$ unter Schütteln inkubiert. Die transformierten Bakterien wurden nun auf den entsprechenden Selektivplatten ausplattiert und bei $37^{\circ} \mathrm{C}$ üN inkubiert.

\subsubsection{Isolierung von Nukleinsäuren}

\subsubsection{Minipräparation von Plasmid- DNA aus Escherichia coli}

Die Isolierung von Plasmid- DNA im analytischen Maßstab (Minipräparation) wurde mit den Lösungen P1, P2 und P3 von Qiagen mittels einer modifizierten Form der alkalischen Lyse (Birnboim und Doly, 1979) vorgenommen. Zur Anzucht einzelner Escherichia- coli- Kolonien wurden diese in $5 \mathrm{ml}$ LB- Medium, welches mit dem entsprechenden Antibiotikum versetzt war, gegeben und üN bei $37^{\circ} \mathrm{C}$ unter Schütteln inkubiert. Zur Sicherung des angezüchteten Bakterienstocks wurden $700 \mu \mathrm{l}$ der Gesamtmenge abgenommen und mit $300 \mu \mathrm{l}$ sterilem Glycerin gut durchmischt. Der Stock wurde bei $-80^{\circ} \mathrm{C}$ gelagert. 
Für die eigentliche Minipräparation der Kulturen wurden diese bei $4^{\circ} \mathrm{C}$ und $4.000 \times \mathrm{g}$ für $10 \mathrm{~min}$ abzentrifugiert. Das Pellet wurde in $100 \mu \mathrm{l}$ kaltem Puffer P1 resuspendiert und durch Zugabe von $200 \mu$ Puffer P2 die alkalische Lyse der Bakterienzellen eingeleitet. Der Ansatz wurde nach vorsichtiger Mischung 5 min bei RT inkubiert. Um die alkalischen Lyse zu stoppen, wurden nun 150 $\mu l$ Puffer P3 zugegeben. Die Trennung der Proteine und genomischen DNA vom Plasmid erfolgte durch 20minütige Zentrifugation bei 15.000 x g. Der Plasmid- haltige Überstand wurde durch Zugabe von $1000 \mu \mathrm{l}$ Isopropanol gefällt und 15 min bei $15.000 \times$ g zentrifugiert. Das entstandene Pellet wurde in $70 \% \mathrm{EtOH}$ gewaschen, bei RT getrocknet und in $30 \mu \mathrm{I} \mathrm{H}_{2} \mathrm{O}$ aufgenommen.

\subsubsection{Endotoxin- freie Maxipräparation von Plasmid- DNA aus Escherichia coli}

Zur Präparation qualitativ hochreiner Plasmid- DNA in größeren Mengen für Transfektionen wurde das Maxi- Kit der Firma Qiagen verwendet. Die Methode beruht auf der alkalischen Lyse der Bakterienzelle (Birnboim und Doly 1979). Zur Anzucht der Escherichia- coli- Kolonien wurden diese in $5 \mathrm{ml}$ mit dem entsprechenden Antibiotikum versetzten LB- Medium für $10 \mathrm{~h}$ bei $37^{\circ} \mathrm{C}$ geschüttelt. Die angezüchteten Bakterien wurden anschließend in 250 $\mathrm{ml}$ des LB- Mediums überführt und bei $37^{\circ} \mathrm{C}$ üN unter Schütteln inkubiert.

Die Kulturen wurden am nächsten Tag für $15 \mathrm{~min}$ bei $4000 \times \mathrm{g}$ und $4^{\circ} \mathrm{C}$ abzentrifugiert und das Pellet in $10 \mathrm{ml}$ kaltem Puffer P1 resuspendiert. Durch Zugabe von $10 \mathrm{ml}$ Puffer P2 wurde die alkalische Lyse eingeleitet. Es folgte eine fünfminütige Inkubation bei RT. Durch die Zugabe von $10 \mathrm{ml}$ Puffer P3 wurde die Lyse gestoppt und das Lysat durch den QIAfilter- Maxi- Cartridge gedrückt. Die Filtration diente der Entfernung der Zelltrümmer, Proteine und Salzkomplexe. Dem Lysat wurden $2 \mathrm{ml}$ Puffer ER beigemengt. Es folgte eine 30 minütige Inkubation auf Eis. Die Äquilibrierung der Anionenaustauschersäule mit $10 \mathrm{ml}$ Puffer QBT erfolgte während der Inkubationszeit. Das Lysat wurde anschließend auf die Säule gegeben. Die gebundene DNA wurde anschließend zweimal mit je $30 \mathrm{ml}$ Puffer QC gewaschen und mittels $15 \mathrm{ml}$ Puffer $\mathrm{QN}$ in ein steriles Endotoxin- freies 
Zentrifugenröhrchen aus Glas eluiert. Durch Zugabe von 10,5 ml Isopropanol kam es zur Fällung der DNA. Es folgte eine Zentrifugation für $30 \mathrm{~min}$ bei $10.000 \mathrm{xg}$ bei $4^{\circ} \mathrm{C}$. Das Pellet wurde in $5 \mathrm{ml} 70 \% \mathrm{EtOH}$ in Endotoxin-freiem Wasser gewaschen, getrocknet und in 100-150 $\mu \mathrm{l}$ Ampuwa aufgenommen.

\subsubsection{Isolierung von genomischer DNA aus eukaryotischen Zellen} (nach Laird et al. 1991)

Für die Isolierung genomischer DNA aus Zellen wurden konfluent bewachsene 6- oder 24- Well- Kulturplatten zunächst mit PBS gewaschen. Nach Zugabe von Lysispuffer für Zellen und Proteinase $\mathrm{K}$ in einem Volumen von $1 / 100$ erfolgte die Inkubation bei $37^{\circ} \mathrm{C}$ üN. Am nächsten Tag wurde zunächst zentrifugiert und der Überstand mit 0,7 Volumen Isopropanol versetzt, um die DNA zu fällen. Anschließend wurde bei $15.000 \times \mathrm{g}$ für 5 min zentrifugiert. Der Überstand wurde verworfen und das Pellet einmal in 70\%igem Ethanol gewaschen. Anschließend wurde die DNA in $80 \mu \mathrm{l} \mathrm{H}_{2} \mathrm{O}$ aufgenommen.

\subsubsection{Isolierung von genomischer DNA aus Geweben}

(nach Laird et al. 1991)

Für die Genotypisierung von Mäusen wurde diesen ein $1 \mathrm{~cm}$ langes Stück der Schwanzspitze abgetrennt. Dieses wurde in $700 \mu l$ Lysispuffer für Gewebe und $35 \mu \mathrm{l}$ Proteinase $\mathrm{K}(10 \mu \mathrm{g} / \mu \mathrm{l})$ überführt und dann üN bei $55^{\circ} \mathrm{C}$ unter Schütteln inkubiert. Nach Zentrifugation wurde der Überstand mit 0,7 Volumen Isopropanol versetzt, um die DNA zu fällen. Nach 5 minütigem Zentrifugieren bei $15.000 \times \mathrm{g}$ wurde der Überstand verworfen und das Pellet einmal mit 70\%igem Ethanol gewaschen und anschließend in $80 \mu \mathrm{l}$ Ampuwa aufgenommen.

\subsubsection{Isolierung von Gesamt- RNA}

Um die Glaswaren von RNasen zu befreien, wurden diese für die Experimente mit RNA bei ca. $200{ }^{\circ} \mathrm{C}$ für mehrere Stunden sterilisiert. Um eine Kontamination mit RNasen $z u$ vermeiden, wurde bei der 
Gewebepräparation und in der Zellkultur stets mit Handschuhen gearbeitet. Das frisch präparierte Gewebe und die Zellen wurden bis zur RNA- Isolierung bei $-80^{\circ} \mathrm{C}$ gelagert und die anschließenden Arbeitsschritte auf Eis oder im Kühlraum durchgeführt.

\subsubsection{Isolierung von Gesamt- RNA aus eukaryotischen Zellen}

Für die Isolierung von RNA wurde TriReagent von Sigma genutzt. Die Zellen wurden mit PBS gewaschen, anschließend wurde der Lysispuffer hinzugeben und 5 min bei RT inkubiert. Die Zellen wurden mit einem Zellschaber vom Boden des Kulturgefäßes gelöst und die Zellsuspension in ein RNase-freies Reaktionsgefäß überführt. Nach Zugabe von 0,2 Volumen Chloroform, wurde der Ansatz gut gemischt, 15 min bei RT inkubiert und dann 15 min bei 15.000 $x \mathrm{~g}$ bei $4^{\circ} \mathrm{C}$ zentrifugiert. Es folgte die Abnahme der oberen RNAenthaltenden Phase und deren Überführung in ein neues Reaktionsgefäß. Zur Fällung der RNA wurden 0,7 Volumen Isopropanol zugegeben und 10 min bei RT inkubiert. Anschließend erfolgte eine 10 minütige Zentrifugation $\left(15.000 \times \mathrm{g}, 4^{\circ} \mathrm{C}\right)$ und das Waschen des Pellets in $70 \% \mathrm{EtOH}$. Das Pellet wurde bei RT getrocknet bevor es in $\mathrm{H}_{2} \mathrm{O}$ aufgenommen und 10 min bei $55^{\circ} \mathrm{C}$ inkubiert wurde.

\subsubsection{Isolierung von RNA aus Geweben}

Zur Isolierung von RNA aus Geweben wurde $100 \mathrm{mg}$ frisches Gewebe in 1 $\mathrm{ml}$ Lysispuffer (TriReagent von Sigma) gegeben. Es erfolgte die Homogenisierung. Die Suspension wurde für 5 min bei RT inkubiert bevor $200 \mu$ Chloroform hinzugegeben wurden. Die Folgeschritte entsprachen der Methode 2.4.2.6.

\subsubsection{Isolierung von RNA aus Embryonen}

Zur Isolierung von Gesamt- RNA aus Embryonen wurde das RNeasy Mini Kit von Qiagen verwendet. Zunächst wurden die isolierten Embryonen (50 bzw. 100). mit $250 \mu \mathrm{l}$ RLT- Puffer (beinhaltet $\beta$-Mercaptoethanol) gut gemischt und der Ansatz auf eine QIAShredder- Säule mit Sammelgefäß überführt. Nach 2- 
minütiger Zentrifugation mit 12000x g bei RT wurde dem Ansatz 1 Volumen 70\%iges Ethanol zugeführt. Die Lösung wurde auf die RNeasy- mini- SpinSäule gegeben und für $15 \mathrm{~s}$ mit $8000 \mathrm{x}$ g bei RT zentrifugiert. Die RNA, die im Filter gebunden wurde, wurde mit $700 \mu \mathrm{l}$ RW1- Puffer und anschließend $2 x$ mit $500 \mu \mathrm{l}$ RPE- Puffer durch 15- sekündige Zentrifugation gewaschen. Zur Trocknung der Membran wurde diese 2 min mit 8000x g bei RT zentrifugiert. Die gewonnene RNA wurde mit $30 \mu \mathrm{l}$ RNase- freiem $\mathrm{H}_{2} \mathrm{O}$ aus dem Filter eluiert.

\subsubsection{Herstellung von komplementärer DNA durch Reverse Transkription}

Die Reverse- Transkriptase- PCR (RT- PCR) wurde für Genexpressionsuntersuchungen verwendet. Sie benötigt eine DNA- Matrize als Substrat, so dass die isolierte RNA zunächst einmal mittels Reverser Transkription in komplementäre DNA (cDNA) umgeschrieben werden muss. Die benötigte doppelsträngige Ansatzstelle für die SuperScript- II- ReverseTranskriptase wird durch den Oligo- dT- Primer und die PolyA- Sequenz der mRNA gebildet.

Für die Reverse Transkription wurden $5 \mu \mathrm{g}$ RNA, $1 \mu \mathrm{l}$ dNTP- Mix und1 $\mu \mathrm{l}$ Oligo-dT- Primer mit sterilem $\mathrm{H}_{2} \mathrm{O}$ auf $13 \mu \mathrm{l}$ aufgefüllt. Die Lösung wurde für 5 min bei $65^{\circ} \mathrm{C}$ denaturiert und anschließend $4 \mu \mathrm{l} 5 \mathrm{x}$ First- Strand- Puffer und 2 $\mu$ l 0,1 M DTT beigemengt. Nach Inkubation für 2 min bei $42^{\circ} \mathrm{C}$ erfolgte die Zugabe von $1 \mu \mathrm{l}$ (200 U) SuperScript- II- Reverse- Transkriptase. Die cDNASynthese wurde gestartet. Nach 50 min wurde die Reaktion durch eine 15minütige Inkubation bei $70^{\circ} \mathrm{C}$ gestoppt.

\subsubsection{Konzentrationsbestimmung von Nukleinsäuren}

Durch die photometrische Messung der Absorption wurde die Konzentration der Nukleinsäuren bestimmt. $2 \mu \mathrm{l}$ der zu messenden Probe wurden hierzu mit $398 \mu \mathrm{l}$ sterilem $\mathrm{H}_{2} \mathrm{O}$ gemischt. Die Messung erfolgte bei $260 \mathrm{~nm}$ und 320 $\mathrm{nm}$ in einer Quarzküvette gegen $400 \mu \mathrm{l}$ steriles $\mathrm{H}_{2} \mathrm{O}$. Mit folgender Formel wurde die Konzentration berechnet: 
$C=(E 260-E 320) \times f \times C$

$\mathrm{C}=$ Konzentration der Probe in $\mu \mathrm{g} / \mu \mathrm{l}$

E260 = Absorption der Probe bei $260 \mathrm{~nm}$

E320 = Absorption der Probe bei $320 \mathrm{~nm}$

$\mathrm{f}=$ Verdünnungsfaktor

$\mathrm{c}=$ Konzentration / Absorption

\subsubsection{Gelelektrophoretische Methoden}

\subsubsection{Agarosegelelektrophorese von DNA}

Für die Auftrennung von DNA- Fragmenten wurden Agarosegele verwendet. Je nach Größe der zu trennenden Fragmente wurden die Gele in einer 0,8\% bis 1,5\%igen Agarosekonzentration in 0,5fachem TBE- Puffer hergestellt. Zur vollständigen Auflösung der Agarose wurde der Ansatz aufgekocht und anschließend Ethidiumbromid in einer Endkonzentration von $0,5 \mu \mathrm{g} / \mathrm{ml}$ hinzugegeben. Nachdem die Gele in eine Gelkammer gegossen worden waren, erfolgte die Abkühlung bei $4^{\circ} \mathrm{C}$ bis zur Aushärtung. Die Gele wurden mit 0,5fachem TBE- Puffer überschichtet. Nach Auftragung der mit Stop- Mix vermischten DNA wurde im Spannungsbereich von 60 bis $120 \mathrm{~V}$ die Elektrophorese durchgeführt. Die DNA- Fragmente wurden durch das interkalierende Ethidiumbromid unter UV- Licht bei $354 \mathrm{~nm}$ als Banden sichtbar. Dadurch wurden die Analyse sowie die photographische Dokumentation der Elektrophorese auf dem UV- Transilluminator möglich. Durch den Vergleich mit einer 1- kb- DNA- Leiter als Längenstandard erfolgte die Größenbestimmung der DNA- Fragmente.

\subsubsection{Agarosegelelektrophorese von RNA}

(Hodge 1994)

Dem 1\%igen Agarosegel (gelöst in 1x MOPS- Puffer, angesetzt mit DEPC$\mathrm{H}_{2} \mathrm{O}$ ) wurde eine Formaldehyd-Lösung hinzugegeben (Endkonzentration: $6.6 \%$ ), um die Rückbildung der Sekundärstruktur der RNA während der Gelelektrophorese zu vermeiden. Für die Auftrennung der RNA wurden folgende Reagenzien zu einem Gesamtansatz von $20 \mu$ zusammengegeben: 


$\begin{array}{rl}\mathrm{x} \mu \mathrm{l} & 10-20 \mu \mathrm{g} \text { Gesamt- RNA } \\ 2 \mu \mathrm{l} & 10 \mathrm{x} \text { MOPS- Puffer } \\ 8 \mu \mathrm{l} & \text { deionisiertes Formamid } \\ 3 \mu \mathrm{l} & \text { Formaldehyd (37\%ige Lösung) } \\ 1.5 \mu \mathrm{l} & \text { Ethidiumbromid } \\ 20 \mu \mathrm{l} & \text { Gesamtansatz, aufgefüllt mit DEPC- } \mathrm{H}_{2} \mathrm{O} .\end{array}$

Zur Denaturierung wurde der Ansatz für 10 min auf $65^{\circ} \mathrm{C}$ erhitzt und anschließend zur Abkühlung 5 min auf Eis gestellt. Nach Zugabe von 0.2 Volumen Stop- Mix zu den RNA- Proben erfolgte die gelelektrophoretische Auftrennung bei einer Spannung von $20 \mathrm{~V}$ bei $4^{\circ} \mathrm{C}$ üN.

\subsubsection{Aufreinigung von DNA}

\subsubsection{Linearisierung und Aufreinigung von Konstrukten vor der Transfektion}

Zur Erhöhung der Transfektionseffizienz wurden die Konstrukte vor der Transfektion linearisiert. Es wurden ca. $100 \mu \mathrm{g}$ der DNA in einem Gesamtansatz von $100 \quad \mu \mathrm{l}$ mit $80-100 \quad \mathrm{U}$ eines geeigneten Restriktionsenzyms angesetzt und üN bei $37^{\circ} \mathrm{C}$ verdaut. Zur Kontrolle der Restriktion wurden anschließend $3 \mu \mathrm{l}$ des Ansatzes auf ein Agarosegel aufgetragen und elektrophoretisch aufgetrennt.

Nach Sicherstellung einer erfolgreichen Linearisierung der DNA wurde eine Phenol- Chloroform- Extraktion des Ansatzes durchgeführt. Um die Sterilität gewährleisten zu können, wurde unter der Sterilbank gearbeitet. Für die Phenol- Chloroform- Extraktion wurde der Ansatz zunächst mit sterilem $\mathrm{H}_{2} \mathrm{O}$ auf $400 \mu \mathrm{l}$ aufgefüllt. Anschließend wurden jeweils $200 \mu \mathrm{l}$ Phenol und Chloroform zugegeben und sorgfältig gemischt. Nach 15- minütiger Zentrifugation bei $15.000 \times \mathrm{g}$ wurde die wässrige obere Phase in ein neues Reagenzgefäß, welches $400 \mu \mathrm{l}$ Chloroform enthielt, überführt. Nach sorgfältigem Mischen wurde nochmals für $15 \mathrm{~min}$ bei $15.000 \mathrm{x}$ g zentrifugiert. Sodann erfolgte erneut die Abnahme und Überführung der oberen Phase in ein neues, steriles Reaktionsgefäß und die Zugabe von $350 \mu$ I Isopropanol 
zur Fällung der DNA. Der Ansatz wurde für $15 \mathrm{~min}$ bei $15.000 \times \mathrm{g}$ zentrifugiert. Der Überstand wurde abgegossen und das DNA- enthaltende Pellet zweimal mit 70\%igem Ethanol gewaschen. Anschließend wurde das Pellet getrocknet und in $100 \mu$ PBS aufgenommen. Die Konzentration der aufgereinigten DNA wurde photometrisch gemessen und zusätzlich zur Kontrolle eine Agarosegelelektrophorese (2.4.5.1) mit $2 \mu \mathrm{l}$ der DNA durchgeführt.

\subsubsection{Isolierung von DNA- Fragmenten aus Agarosegelen}

Um DNA- Fragmente aus Agarosegelen zu isolieren, wurde das QIAquick® Gel Extraktion Kit verwendet. Nach gelelektrophoretischer Auftrennung der DNA wurde das Gel auf einen Transilluminator unter UV- Licht (354 nm) gelegt, das entsprechende DNA- Fragment mit einem sterilen Skalpell herausgeschnitten und in ein steriles Reaktionsgefäß gegeben. Anschließend wurde das DNA- Fragment gewogen, die entsprechende Menge des im Kit enthaltenen QG- Puffers hinzugegeben und für 10 min bei $50^{\circ} \mathrm{C}$ unter Schütteln inkubiert. Der Ansatz wurde auf eine der im Kit enthaltenen Säulen gegeben und für $1 \mathrm{~min}$ bei $15.000 \times \mathrm{g}$ zentrifugiert. Die nun in der Säule gebundene DNA wurde dann mit $750 \mu$ Puffer PE gewaschen und zur Entfernung der restlichen Flüssigkeit erneut für 1 min bei $15.000 \times g$ zentrifugiert. Zur Eluierung der DNA wurden $50 \mu \mathrm{l}$ EB Puffer auf die Säule gegeben und nach kurzer Inkubation erneut zentrifugiert.

\subsubsection{Polymerase- Kettenreaktion (PCR)}

Die PCR- Technik ist eine enzymatische Methode für die in- vitroAmplifikation spezifischer DNA- Fragmente (Saiki et al. 1988). Ausschlaggebend für die Spezifität dieser Amplifikation sind zwei Oligonukleotidprimer, welche das zu amplifizierende DNA- Fragment flankieren und nach einer Denaturierung durch Hitze an den komplementären Strängen binden. Die Synthese des gewünschten DNA- Fragments erfolgt entlang der Sequenz zwischen den Oligonukleotidprimern durch die hitzestabile DNA- Polymerase des Archaebakteriums Thermus aquaticus 
(Taq- Polymerase) (Chien et al. 1976). Die optimale Temperatur der TaqPolymerase liegt bei $72^{\circ} \mathrm{C}$. Die exponentielle Vermehrung des entsprechenden DNA- Fragments wird durch wiederholte Zyklen von Denaturierung der DNA- Stränge, Anlagerung der Primer ("Annealing") und DNA- Synthese ("Elongation") erreicht. Die Automatisierung der PCR in Thermocyclern wird durch den Einsatz der hitzestabilen Taq- Polymerase ermöglicht.

\subsubsection{PCR an Plasmid- DNA}

Um nach Transformation und Minipräparation die Integration der richtigen Sequenz zu bestätigen und anschließend zu sequenzieren, wurde eine PCR an Plasmid- DNA durchgeführt. Hierfür kam das Immolase- Taq- DNAPolymerase- System zum Einsatz. Für einen Gesamtansatz von $25 \mu \mathrm{l}$ wurden folgende Reagenzien benötigt:

$$
\begin{aligned}
& \mathrm{x} \mu \mathrm{l} \text { Plasmid- DNA }(30-50 \mathrm{ng}) \\
& 0,5 \mu \mathrm{l} \text { Primer } 1(10 \mathrm{pmol} / \mu \mathrm{l}) \\
& 0,5 \mu \mathrm{l} \text { Primer } 2(10 \mathrm{pmol} / \mu \mathrm{l}) \\
& 1 \mu \mathrm{l} \text { dNTP- Mix }(\mathrm{je} 10 \mathrm{mM}) \\
& 2,5 \mu \mathrm{l} 10 x \text { PCR- Puffer } \\
& 1,5 \mu \mathrm{l} 50 \mathrm{mM} \mathrm{MgCl}_{2} \\
& 0,5 \mu \mathrm{l} \mathrm{Immolase-} \mathrm{Taq-} \mathrm{DNA-} \mathrm{Polymerase}(5 \mathrm{U} / \mu \mathrm{l}) \\
& \text { auf } 25 \mu \mathrm{l} \text { mit sterilem } \mathrm{H}_{2} \mathrm{O} \text {. }
\end{aligned}
$$

Für die PCR wurden die Ansätze in einem Thermocycler mit nachfolgend aufgeführtem Programm inkubiert:

$\left.\begin{array}{lll}5 \mathrm{~min} & 95^{\circ} \mathrm{C} & \text { Vordenaturierung } \\ 30 \mathrm{sec} & 95^{\circ} \mathrm{C} & \text { Denaturierung } \\ 45 \mathrm{sec} & 55-68^{\circ} \mathrm{C} & \text { Annealing } \\ 1-2 \mathrm{~min} & 72^{\circ} \mathrm{C} & \begin{array}{l}\text { Elongation } \\ 7 \mathrm{~min}\end{array} \\ 72^{\circ} \mathrm{C} & \text { Auffüllreaktion }\end{array}\right\} 30-35$ Zyklen


Die jeweilige spezifische Annealing-Temperatur wurde je nach Kombination der Primer verändert, um die für die verwendeten Primerpaare optimale Temperatur zu finden. Mittels Agarose- Gelelektrophorese wurde das Produkt der PCR nach der Amplifikation überprüft.

\subsubsection{PCR an genomischer DNA}

Zur Amplifizierung von Sonden für die Hybridisierung und für die Genotypisierung von Mäusen und Zellen wurde eine PCR an genomischer DNA durchgeführt. Die Vorgehensweise bezüglich der Ansätze und PCRProgramme entsprach der unter 2.4.8.1 beschriebenen.

\subsubsection{RT- PCR}

Die RT- PCR (Reverse Transkriptions- PCR) wird zur Amplifikation von cDNA- Sequenzen genutzt. Die cDNA- Sequenzen werden zuvor durch invitro- Transkription mit Hilfe des Enzyms Reverse Transkriptase aus mRNA erzeugt. Kleinste Transkriptmengen von bestimmten Genen in Organen und Zellen können so mittels RT- PCR detektiert werden. Es wurde wie unter 2.4.8.1 verfahren. Die Ansätze und Programme wurden auch hier für jedes Primerpaar spezifisch durchgeführt.

\subsubsection{Sequenzierung von PCR- Produkten}

(nach Sanger et al. 1977)

Die Sequenzierung von PCR- Produkten nach dem Kettenabbruchverfahren beruht auf dem Prinzip statistisch unterbrochener DNA- Neusynthese durch den Einbau von Didesoxynukleosiden (ddNTPs). Bei dieser Methode bindet sich analog zu einer PCR ein sequenzspezifischer Primer an die denaturierte DNA. Eine hitzestabile DNA- Polymerase kann so einen komplementären DNA- Strang synthetisieren. Anders als bei der PCR werden nun jedoch nicht nur dNTPs verwendet, sondern zusätzlich vier unterschiedliche ddNTPs. Diese sind mit jeweils unterschiedlichen Fluoreszenzfarbstoffen markiert. Nach Einbau der ddNTPs bei der Synthese kommt es zu einem Strangabbruch, so dass per Zufall unterschiedlich große DNA- Fragmente 
entstehen. Die Position des Kettenabbruchs kann nach einer elektrophoretischen Auftrennung durch Fluorographie sichtbar gemacht werden. Ein Rückschluss auf die Sequenz wird hierdurch möglich.

Folgender Reaktionsansatz wurde für die Sequenzanalyse verwendet:

0,5 - $2 \mu \mathrm{l}$ PCR-Produkt $(1-1,5 \mu \mathrm{g})$

$1 \mu \mathrm{l}$ Primer $(10 \mathrm{pmol} / \mu \mathrm{l})$

4 l DYEnamic ${ }^{\text {TM }}$ ET-Mix (dNTPs, ddNTPs, Taq- DNA- Polymerase, Reaktionspuffer)

auf $10 \mu \mathrm{l}$ mit sterilem $\mathrm{H}_{2} \mathrm{O}$.

Folgendes Programm wurde für die Kettenabbruchreaktion in einem automatischen Thermocycler verwendet:

$\left.\begin{array}{lll}40 \mathrm{sec} & 95^{\circ} \mathrm{C} & \text { Vordenaturierung } \\ 20 \mathrm{sec} & 95^{\circ} \mathrm{C} & \text { Denaturierung } \\ 25 \mathrm{sec} & 55^{-68^{\circ} \mathrm{C}} & \begin{array}{l}\text { Annealing } \\ 1 \mathrm{~min}\end{array} \\ 72^{\circ} \mathrm{C} & \text { Elongation }\end{array}\right\} 25$ Zyklen

Für die automatische Sequenzierung mit dem Sequenzierer MegaBace1000 wurden die Proben mit sterilem Wasser auf $20 \mu \mathrm{l}$ aufgefüllt. Durch den Vergleich mit der Referenzsequenz (www.ncbi.nlm.nih.gov) erfolgte die Sequenzanalyse.

\subsubsection{Radioaktive Markierung von DNA ("random prime labelling")}

(Feinberg und Vogelstein 1983)

Die DNA- Fragmente wurden durch die "random prime labelling"- Methode für Hybridisierungsexperimente radioaktiv markiert (Feinberg und Vogelstein 1983). Das Ready prime ${ }^{\mathrm{TM}}$ II-random prime labelling- System wurde zum Einbau von $\left[\alpha^{32} \mathrm{P}\right]$ dCTP für die Markierungsreaktion genutzt. Für die Denaturierung der DNA wurden 2,5-25 ng DNA in $46 \mu \mathrm{l}$ TE- Puffer gegeben und für 2 min bei $95^{\circ} \mathrm{C}$ inkubiert. Nach Abkühlung wurde der Ansatz in das 
Reaktionsgefäß mit dem Ready- prime- Pellet (dATP, dGTP, dTTP, Klenow Fragment 4-8 U) überführt und $40 \mu \mathrm{Ci}\left[\alpha^{-32} \mathrm{P}\right] \mathrm{dCTP}$ hinzugegeben. Nach einstündiger Inkubation bei $37^{\circ} \mathrm{C}$ wurde der Ansatz zur Entfernung der nicht eingebauten Nukleotide (dNTPs und $\left[\alpha^{-}{ }^{32} P\right]$ dCTP) auf eine MicroSpin- Säule (Amersham Pharmacia) gegeben. Anschließend konnte die so gereinigte und markierte Sonde entweder bei $4^{\circ} \mathrm{C}$ bis zur weiteren Verwendung gelagert oder aber nach 10 - minütiger Denaturierung bei $95^{\circ} \mathrm{C}$ sofort eingesetzt werden.

\subsubsection{Transfertechniken und Hybridisierung}

\subsubsection{Transfer von RNA aus Agarosegelen: Northern- Blotting}

Der Transfer von RNA auf nukleinsäurebindende Membranen wird als Northern- Blotting bezeichnet. Für das modifizierte Kapillarblotting- Verfahren wurde der Turbo Blotter ${ }^{\mathrm{TM}}$ der Firma Schleicher \& Schüll verwendet, mit dessen Hilfe man RNA auf eine Hybond- C- Nitrozellulose- Membran mit nukleinsäurebindenden Eigenschaften übertragen kann. Der Transfer der gelelektrophoretisch aufgetrennten RNA auf die Hybond- C- NitrozelluloseMembran erfolgte nach den Herstellerangaben. Die Positionen der Geltaschen wurden auf der Membran markiert und das Gel anschließend entfernt. Bevor die Membran zur Fixierung der RNA für $2-3 \mathrm{~h}$ bei $80^{\circ} \mathrm{C}$ gebacken wurde, wurde die Spur des RNA- Längenstandards abgeschnitten.

\subsubsection{Radioaktive Hybridisierung von Northern- Blots}

(Denhardt 1966)

Für die radioaktive Hybridisierung der Hybond- C- Nitrozellulose- Membran wurde diese für 10 min in 2x SSC- Lösung eingeweicht. Anschließend wurde die Membran in ein mit 2x SSC gefülltes Hybridisierungstube überführt. Die Membran legte sich an die Wand des Tubes, das SSC wurde abgegossen. Nun wurden 10 ml Rapid- hyp- Puffer (Amersham) bzw. Hybridisierungspuffer (KPL) und $200 \mu \mathrm{l}$ Lachsspermien- DNA $(10 \mathrm{mg} / \mathrm{ml}$, geschert durch Ultraschall) in das Tube gegeben. Zur Vorhybridisierung wurde das Tube für mindestens $2 \mathrm{~h}$ bei $65^{\circ} \mathrm{C}$ in den Rollerofen (Bachofer, Reutlingen) gegeben, 
um unspezifische Bindungsstellen an der Membran abzusättigen. Nach der Vorhybridisierung wurde die radioaktiv markierte DNA-Sonde, die zuvor für 10 min bei $95^{\circ} \mathrm{C}$ denaturiert und auf Eis wieder abgekühlt wurde, hinzugegeben. Zur Hybridisierung wurde das Tube üN wieder in den $65^{\circ} \mathrm{C}$ warmen Rollerofen gegeben. Am nächsten Tag wurde die Hybond- CNitrozellulose- Membran für 10 min mit $2 x \mathrm{SSC}$ bei $65^{\circ} \mathrm{C}$ gewaschen. Für die Reduktion der Stringenz bis zur gewünschten Stärke erfolgte das Waschen in den Waschlösungen I, II und III für jeweils ca. 10 min. Anschließend wurde die Membran mit der radioaktiv markierten RNA luftgetrocknet und in Folie eingeschweißt. So präpariert wurde sie in einer Röntgenfilmkassette befestigt und ein Röntgenfilm (HyperfilmTM- MP) eingelegt. Über einen Zeitraum von wenigen Minuten bis zu mehreren Tagen wurde der Röntgenfilm bei $-80^{\circ} \mathrm{C}$ exponiert, bevor er in einem Entwicklungsgerät entwickelt wurde.

\subsubsection{3 "Strippen" von Membranen}

Für die Entfernung einer Hybridisierungssonde von der Hybond- CNitrozellulose- Membran wurde diese je nach gewünschter Stringenz in Waschlösung I bzw. II bei $65^{\circ} \mathrm{C}$ gewaschen. Bis zu nachfolgenden Hybridisierungen wurde die Membran feucht gehalten.

\subsection{Embryologische Methoden}

\subsubsection{Blastozysteninjektion}

Für die Blastozysteninjektion wurden zunächst die zu injizierenden Zellen mit Hilfe von Trypsin von den Kulturgefäßen gelöst und vereinzelt. Durch die Zugabe des FKS- haltigen Kulturmediums wurde das Trypsin inaktiviert. Die entstandene Zellsuspension wurde auf Eis in die Tierhaltung des MPI für experimentelle Medizin, Göttingen, gebracht. Dort erfolgte die Blastozysteninjektion. Pro Blastozyste wurden ca. 15 bis 25 Zellen injiziert, und die Blastozysten wurden anschließend in pseudoschwangere Mäuse transferiert. 


\subsubsection{Superovulation von Mäusen und Gewinnung von Oozyten}

Die weiblichen Mäuse ovulieren alle 4-5 Tage in etwa 3-5 Stunden nach Einsetzen der Dunkelperiode bei einem vorgegebenen Hell- DunkelRhythmus (7-18, 18-7 Uhr) im Tierstall. Zur Erhöhung der Ausbeute an reifen Eizellen zu einem bestimmten Zeitpunkt wurde eine hormonelle Behandlung der Tiere des Stammes CD1 durchgeführt. Für die Superovulation der Weibchen wurde diesen um 15 Uhr 10 U PMSG i.p. und nach 48 Stunden 10 U hCG i.p. injiziert. PMSG entspricht dem follikelstimulierenden Hormon und hCG dem luteinisierenden Hormon des weiblichen Zyklus. 12 Stunden nach der hCG- Injektion konnten pro Weibchen etwa 10- 20 Oozyten aus den Ovedukten ausgespült werden.

\subsubsection{Isolierung von Präimplantationsembryonen}

Die Isolierung der verschiedenen Embryonalstadien aus den superovulierten Mäusen wurde an den entsprechenden Tagen, errechnet nach dem Vaginal Plug- Check, vorgenommen $\quad(0,5 \mathrm{dpc} \rightarrow 2$-Zeller, $\quad 2,5 \mathrm{dpc} \rightarrow 4-8$-Zeller; $3,5 \mathrm{dpc} \rightarrow$ Morula- Blastozyste). Bei den zur Entnahme getöteten Tieren wurde die Bauchdecke geöffnet, der Uterus mit den Eileitern entnommen und in M2Medium gegeben. Um eine präzisere Präparation zu ermöglichen, wurde die weitere Arbeit unter einem Stereomikroskop (Stemi SV 11, Fa. Zeiss) unter Durchlicht durchgeführt. Die geschwollenen Ampullen bzw. die Uteri wurden mit Hilfe von spitz ausgeschmiedeten Pinzetten angerissen, so dass die frühen Embryonalstadien aufgrund des vorliegenden Überdrucks herausgepresst wurden. Nach dem Herauspräparieren der restlichen Embryonen wurden die leeren Uteri aus den Kulturschalen verworfen. Anschließend wurden mit einem Mundschlauch und einer über dem Bunsenbrenner ausgezogenen Pasteurpipette die frühen Embryonalstadien eingesaugt und mit möglichst wenig Geweberesten in frisches M2- Medium überführt. Auf diese Weise wurde solange weitergewaschen, bis die Präimplantationsembryonen frei von Geweberesten waren. 


\section{Ergebnisse}

Im Rahmen dieser Doktorarbeit sollte die Stra8- Expression im Ovar, in verschiedenen ES- und SSC- Zelllinien und in der frühen Embryonalentwicklung untersucht werden. Auch sollte untersucht werden, ob Stra8 eine Rolle bezüglich der Pluripotenz spielt. Einige Ergebnisse der vorliegenden Arbeit wurden in enger Zusammenarbeit mit Frau Dr. Nolte generiert (Nolte 2008).

\section{1 Expressionsanalyse von Stra8}

\subsubsection{Nachweis der Stra8- Expression im Ovar mittels RT- PCR}

Aus der Literatur ist bekannt, dass Stra8 ein Testis- spezifisches Gen ist, welches in der prämeiotischen Phase der Spermatogenese exprimiert wird (Oulad- Abdelghani et al. 1996). Da Stra8 aber auch in sich entwickelnden Ovarien in den Embryonalstadien 12,5 dpc (days post coitum) bis $14,5 \mathrm{dpc}$ nachgewiesen wurde (Menke et al. 2003) und männliche sowie weibliche homozygote Stra8- defiziente Mäuse infertil sind (Baltus et al. 2006), war von großem Interesse, ob Stra8 auch im Ovar der adulten Maus nachzuweisen ist. Im Rahmen dieser Arbeit wurde die Stra8- Expression in Ovarien von 15 Tage alten und adulten WT- Mäusen untersucht.

Die Gesamt- RNA wurde aus den Ovarien isoliert und in CDNA umgeschrieben. Um sicherzustellen, dass die cDNA- Synthese erfolgreich war, wurde zunächst die HPRT-Kontroll- PCR durchgeführt. 


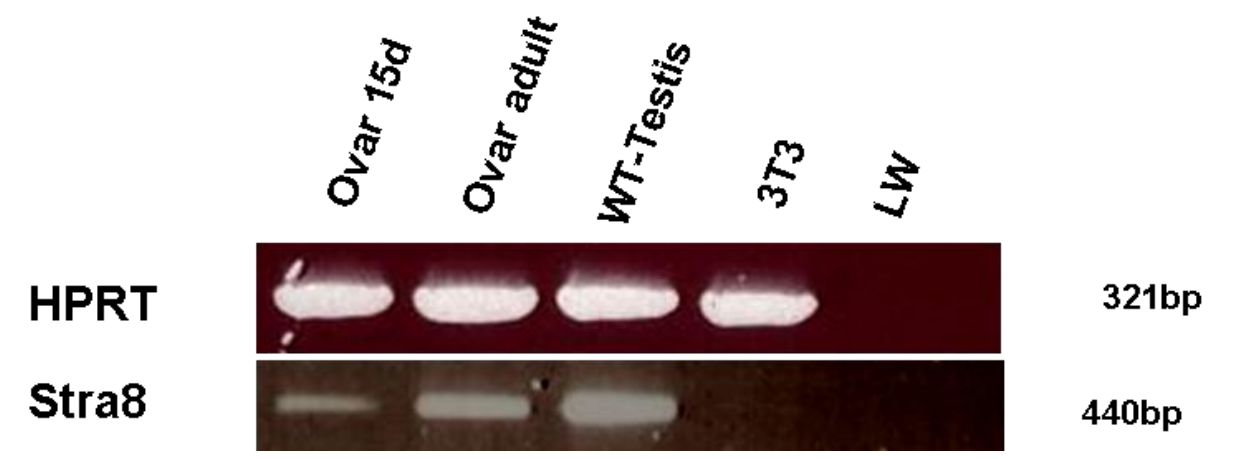

Abbildung 1: Stra8- RT- PCR mit cDNA aus 15 Tage alten und adulten WT- Ovarien

Als Positivkontrolle diente WT- Testis cDNA. Als Negativkontrolle wurde cDNA aus der NIH-3T3- Zellinie (Fibroblasten) verwendet.

$\mathrm{LW}=$ negative Kontrolle ohne Template

Wie Abbildung 1 zeigt, konnte sowohl in den 15 Tage alten als auch in den adulten Ovarien eine Stra8- Expression detektiert werden.

\subsubsection{Immunhistologischer Nachweis der STRA8- Expression im Ovar und im Testis}

Für die Untersuchung der STRA8- Expression auf Proteinebene wurde ein kommerzieller STRA8- Peptidantikörper verwendet, der auf Schnitten von in Paraffin- eingebetteten 7 Tage alten und adulten WT- Testis getestet wurde. Unter dem LSM (Laser- Scanning- Mikroskop) zeigte sich, das nur Typ A und Typ B Spermatogonien sowie präleptotäne und frühe leptotäne Spermatozyten positiv für STRA8 sind (Abb.2). Die genaue Bestimmung der STRA8- positiven Zelltypen wurde von Prof. Andreas Meinardt (Anatomisches Institut, Universität Gießen) durchgeführt. Die Ergebnisse stimmen mit dem aus der Literatur bekannten STRA8- Expressionsmuster exakt überein (Ouldad- Abdelghani et al. 1996; Baltus et al. 2006; Zhou et al. 2008a und b). 


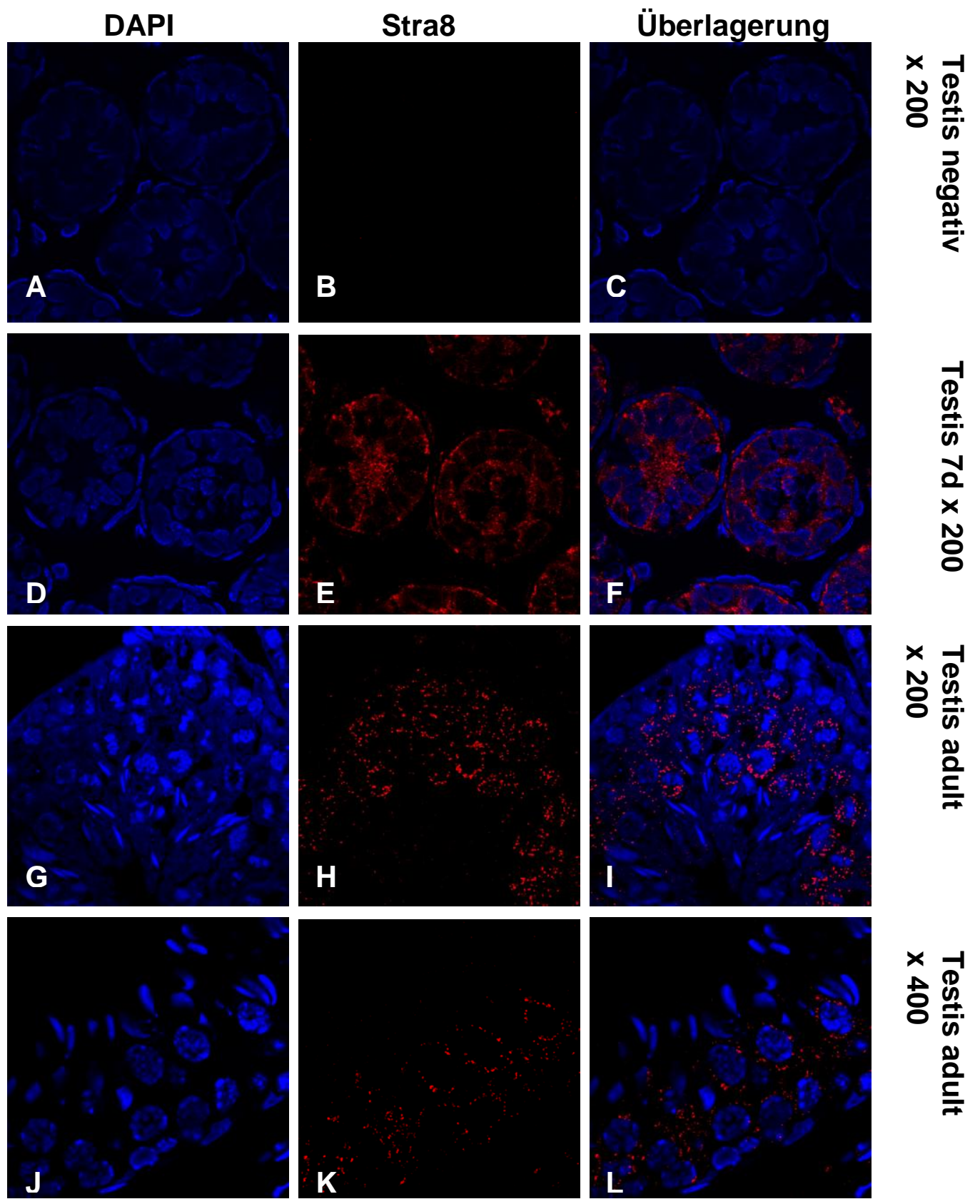

Abbildung 2: STRA8- Antikörperfärbung auf Paraffinschnitten von WTTestis

A-C: Negativkontrolle= adulte WT- Testis (nur sekundärer Antikörper)

D-F: STRA8- Antikörper auf 7 Tage altem WT- Testis

G-L: STRA8- Antikörper auf adultem WT- Testis.

Diese Abbildungen wurden zusammen mit Frau Dr. Nolte erarbeitet (Nolte 2008). 
Durch diesen Vorversuch konnte gezeigt werden, dass der verwendete Antikörper spezifisch für STRA8 ist.

Im nächsten Versuch wurde der STRA8- Antikörper verwendet, um die Zellen im Ovar zu bestimmen, die zu der positiven Stra8- RT- PCR führen. Hierzu wurden Ovarien aus WT- Mäusen verschiedenen Alters (5d, 10d, 15d, 20d, adult) präpariert und die Schnitte immunhistochemisch gefärbt.
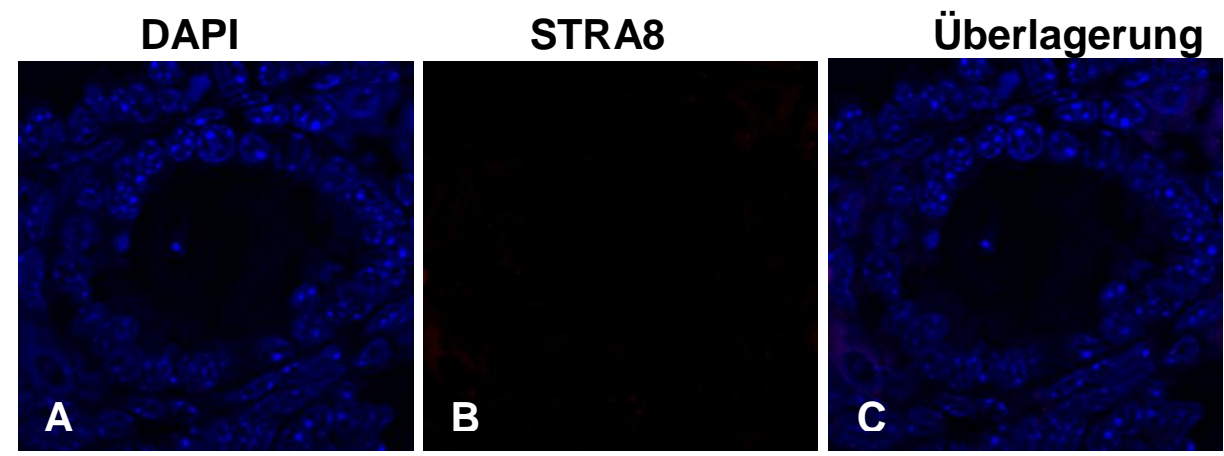

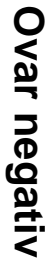
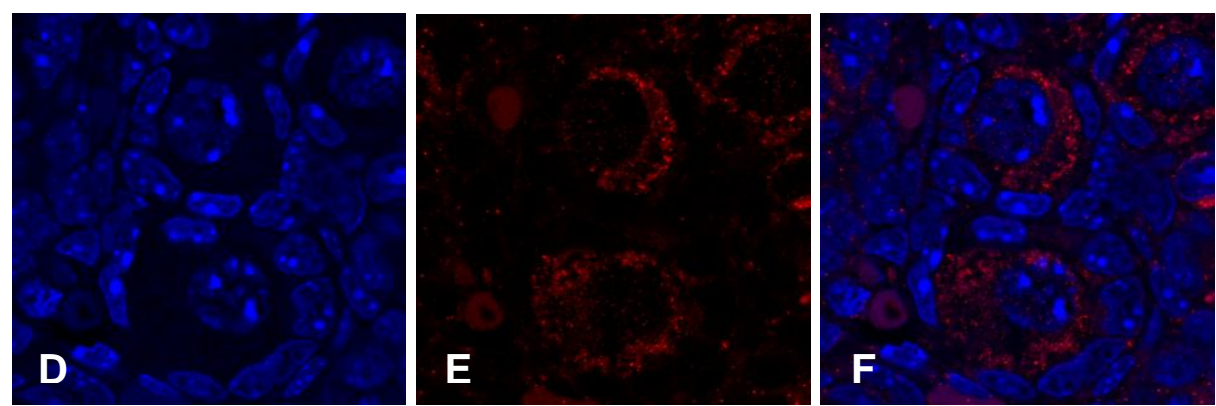

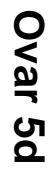
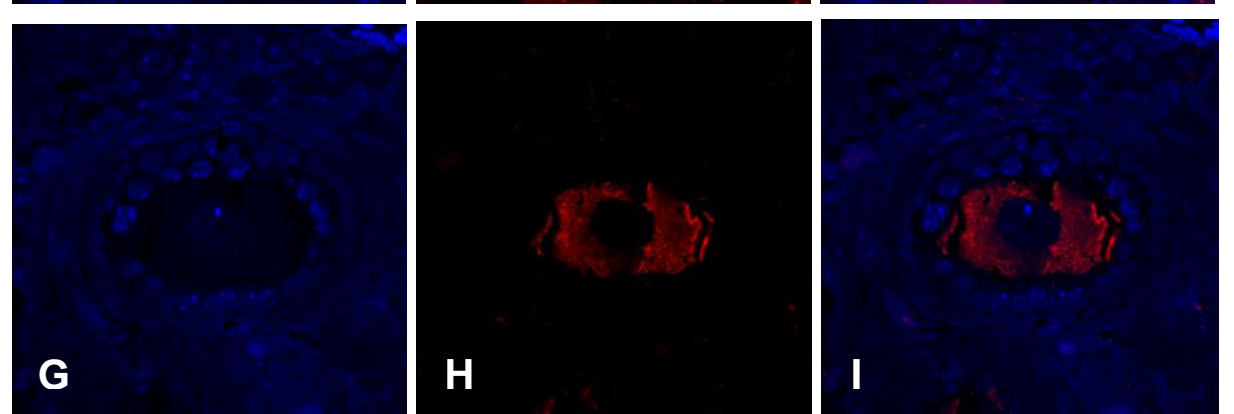

옹
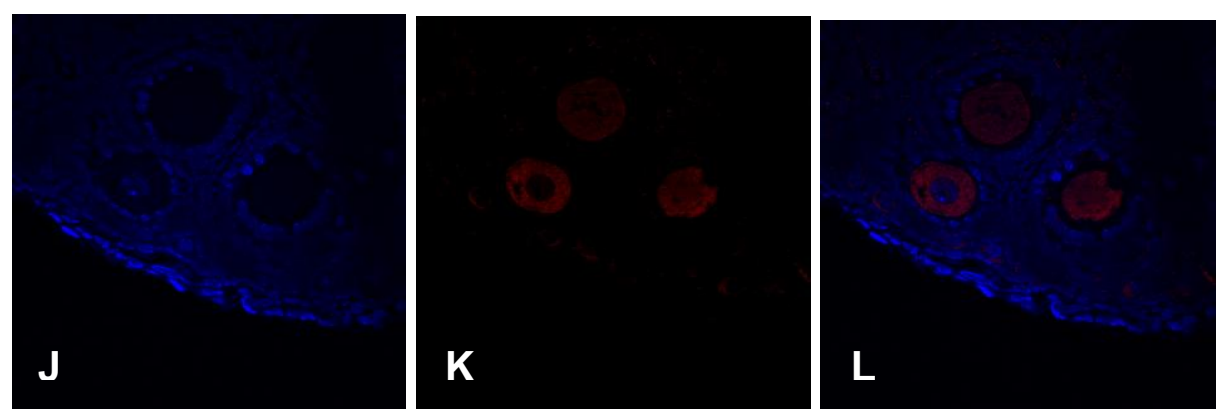

ญ̊ 

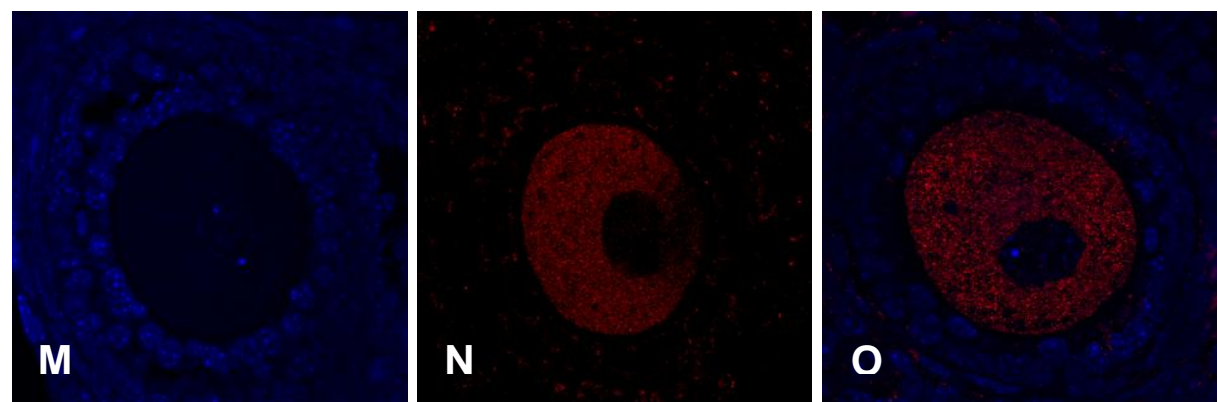

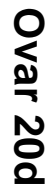
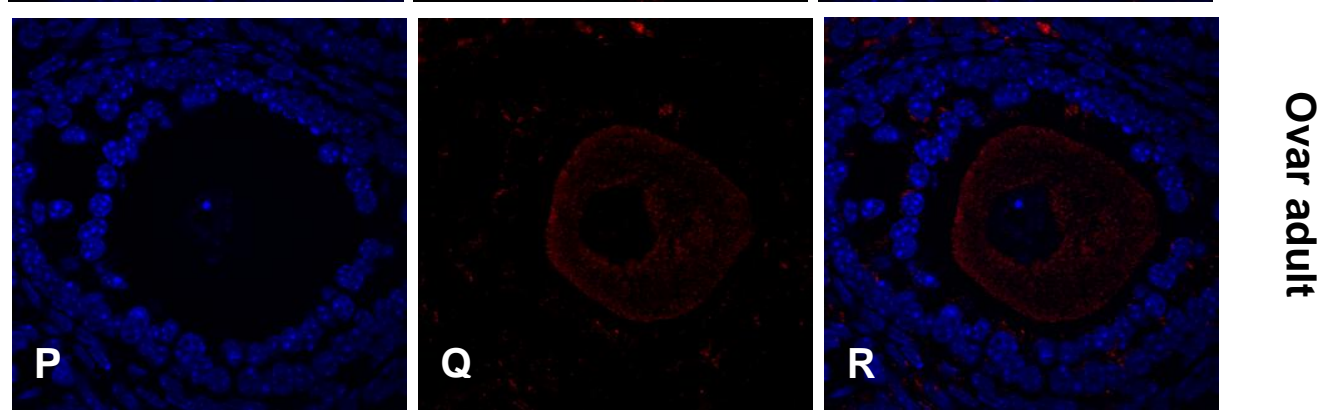

Abbildung 3: STRA8- Antikörperfärbung auf Paraffinschnitten von WT- Ovarien verschiedenen Alters

Die Bilder wurden mit einem 10er Objektiv aufgenommen und mit der zum LSM zugehörigen Software auf Bildausschnittgröße vergrößert.

A, D, G, J, M, P: DAPI (Kernfärbung)

B, E, H, K, N, Q: STRA8 (Су3)

C, F, I, L,O, R: Überlagerung der Fluoreszenzen

Diese Abbildungen wurden zusammen mit Frau

Dr. Nolte erarbeitet (Nolte 2008).

Es konnte gezeigt werden, dass STRA8 in allen Oozyten der verschiedenen Altersstufen exprimiert wird und im Ooplasma lokalisiert ist (Abb.3).

\subsubsection{Nachweis der Stra8- Expression in den ESC- und SSC- Zelllinien}

In unserer Arbeitsgruppe wurden im Rahmen einer biologischen Doktorarbeit SSC- Zelllinien aus WT- Mäusestämmen isoliert (Nolte 2008). Die Zelllinien werden entsprechend ihrer Herkunft bezeichnet (SSC 129 SV, SSC C57BI, SSC FVB), die Zelllinien aus der doppeltransgenen Maus tragen die Bezeichnung SSC15 (isoliert aus der Maus Nr. 15). Aus dieser Maus konnten mehrere klonale Zelllinien generiert werden, die durchnummeriert wurden (z.B. SSC15 Nr.12). 
Im Rahmen dieser Doktorarbeit wurde die Stra8- Expression der verschiedenen SSC- Zelllinien untersucht. Hierzu wurde zunächst nach erfolgreicher HPRT- Kontroll- PCR die Stra8- RT- PCR mit cDNA der SSCZelllinien durchgeführt.

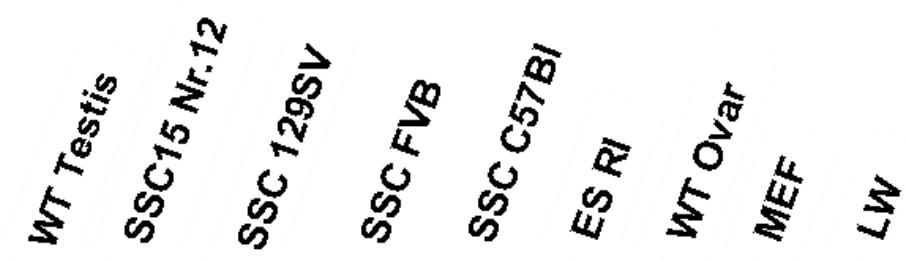

HPRT

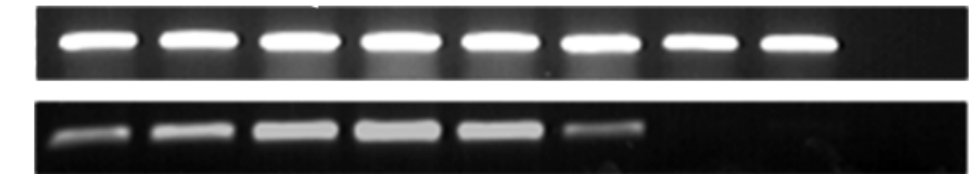

321bp

Stra8

Abbildung 4: Stra8- RT- PCR mit CDNA aus vier SSC- Zelllinien und aus der ES- RI Zelllinie

Als Positivkontrolle dienten WT- Testis sowie -Ovar. Als Negativkontrolle wurden MEFs (embryonale Fibroblasten) eingesetzt. $L W=$ Negativkontrolle ohne Template.

Diese Abbildung wurde zusammen mit Frau Dr. Nolte erarbeitet (Nolte 2008).

Wie Abbildung 4 zeigt, konnte in allen SSC- Zelllinien Stra8- Expression detektiert werden. Im Gegensatz zu den Ergebnissen des vorausgegangenen Versuchs, war ein Nachweis von Stra8 im WT- Ovar nicht möglich. In diesem Versuch wurde jedoch eine ältere WT- Ovar cDNA verwendet. ES- Zelllinien mit denselben genetischen Hintergründen wurden ebenfalls auf Stra8Expression untersucht. Die ES- Zelllinien, die aus der Stra8/EGFPdoppeltransgenen- Maus isoliert wurden, tragen die Bezeichnung ES dt Stra8. 


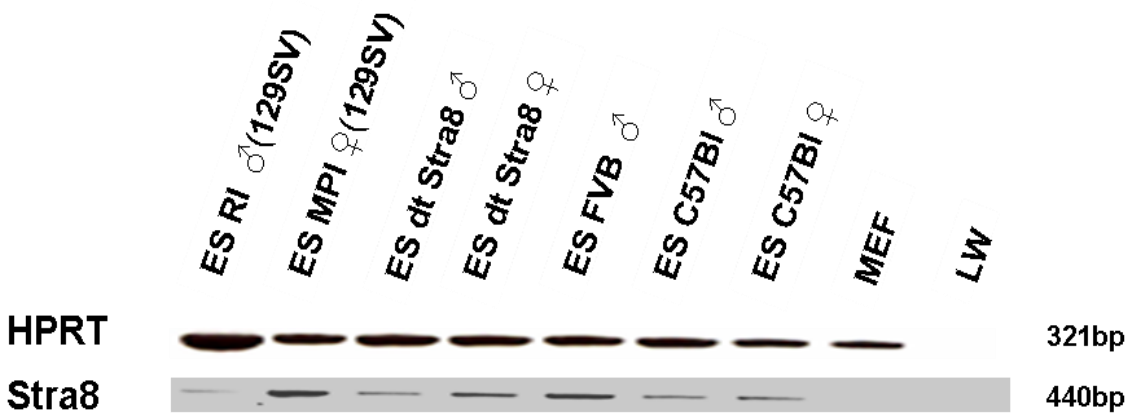

Abbildung 5: Stra8- RT- PCR mit cDNA aus sieben verschiedenen ES- Zelllinien

Positivkontrolle $=\mathrm{ES} \mathrm{RI}$

Negativkontrolle $=$ MEF

Negativkontrolle ohne Template $=$ LW

Wie Abbildung 5 zeigt, konnte sowohl in allen ES- Zelllinien Stra8 mittels RTPCR detektiert werden.

Auszugsweise wurde Stra8- mRNA in den Zelllinien ES C57BI und SSC C57BI mittels Northern- Blot analysiert (Abb.6).
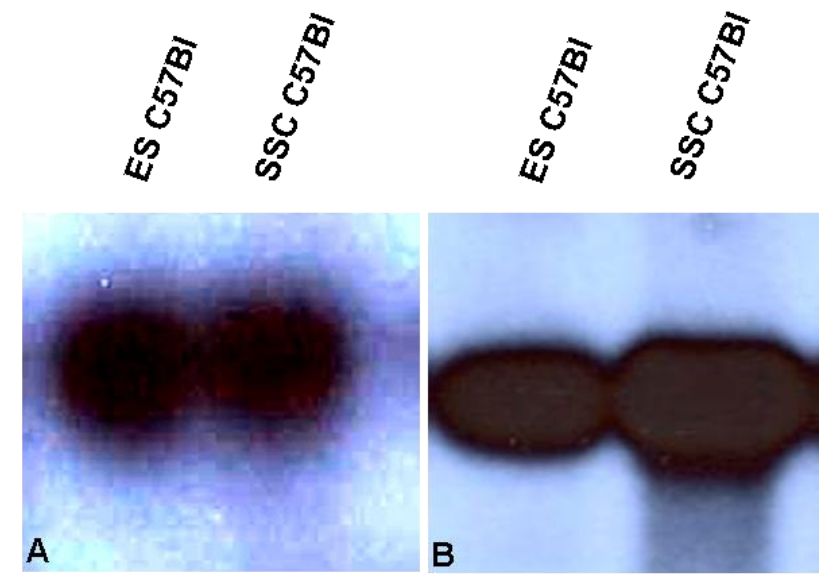

Abbildung 6: Northern- Blot mit RNA aus den Zelllinien ES C57BI und SSC C57BI

A: Stra8-Sonde

B: $\beta$ - Aktin- Sonde

Im nächsten Versuch wurde nun die STRA8- Expression auf Proteinebene mittels immunhistochemischer Färbung in den verschiedenen SSC- und ESZelllinien untersucht (Abb.7). In allen Zelllinien konnte STRA8 nachgewiesen werden. Es konnte gezeigt werden, dass es in den verschiedenen Zelllinien 
sowohl STRA8- positive als auch STRA8- negative Zellen gibt. Dies wird besonders deutlich in den Zelllinien ES-RI (Abb.7F) und SSC 129SV (Abb.7l). Zudem wurde gezeigt, dass STRA8 in einigen Zellen zytoplasmatisch lokalisiert ist, es jedoch auch Zellen gibt, in denen das Protein im Kern lokalisiert ist. In der Zelllinie SSC FVB konnte dies am eindrucksvollsten gezeigt werden (Abb.7Ä).

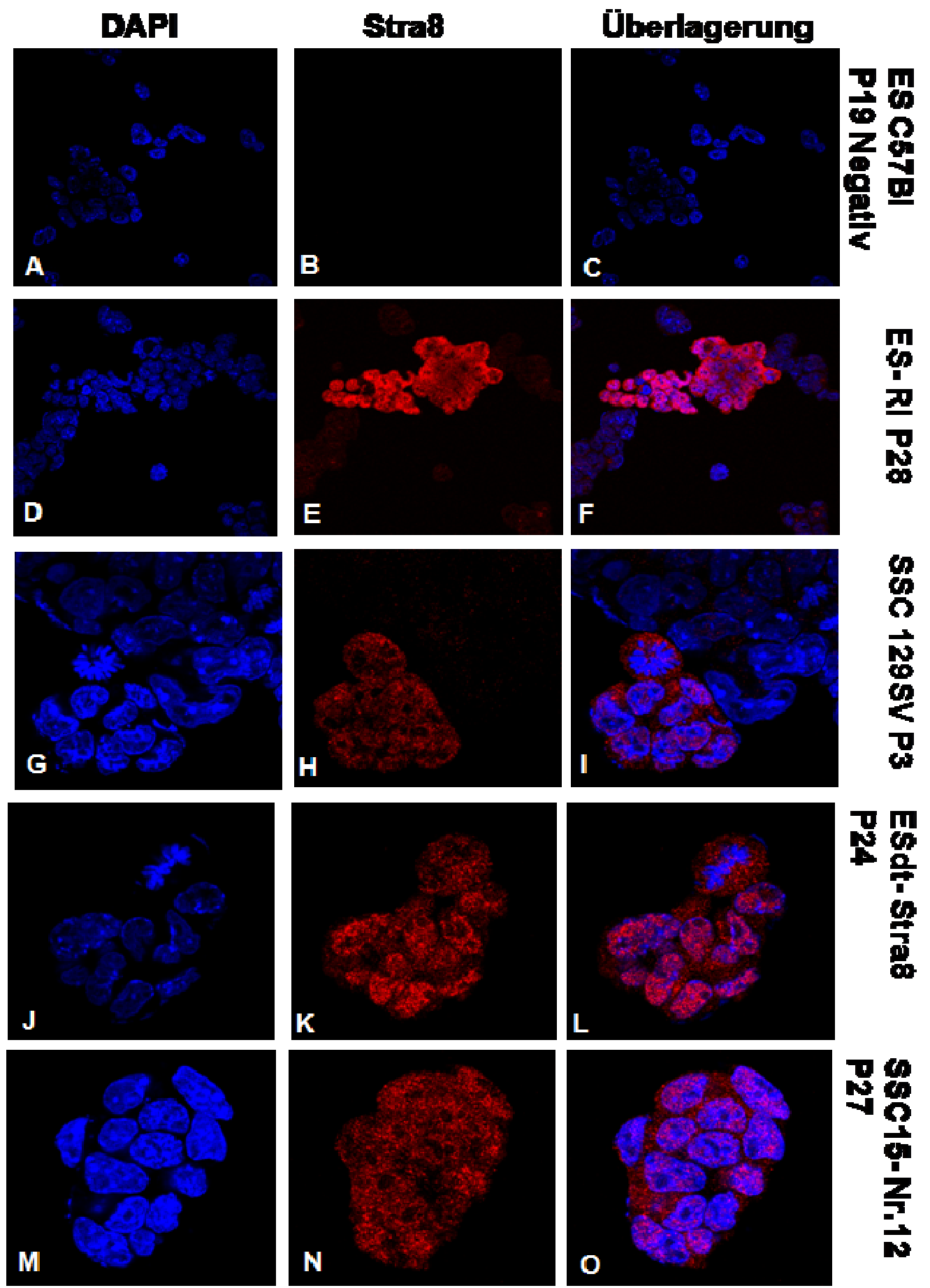




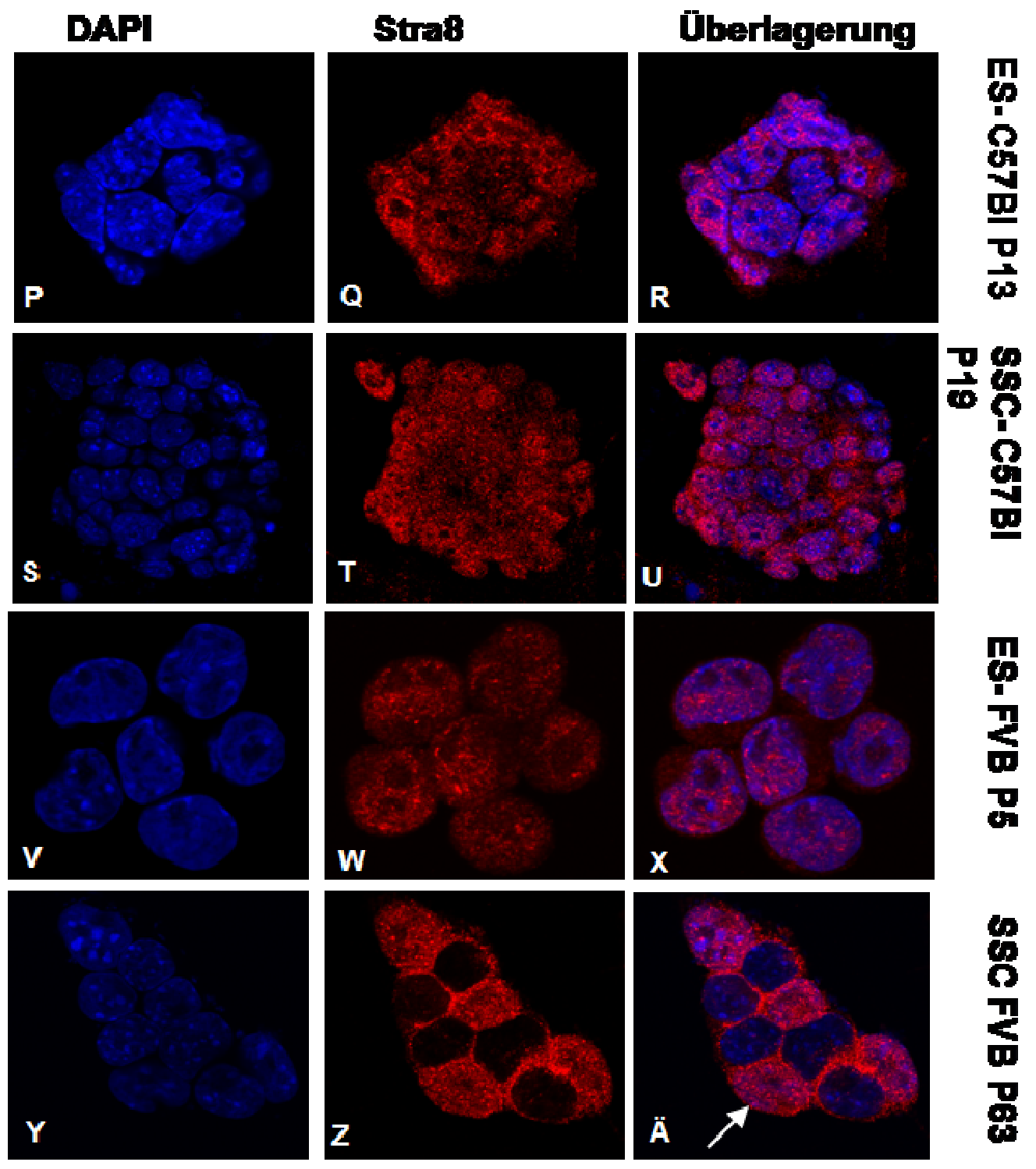

Abbildung 7: STRA8- Antikörperfärbung auf SSC- und ES- Zelllinien

Die Bilder wurden mit einem 10er Objektiv aufgenommen und mit der zum LSM zugehörigen Software auf Bildausschnittgröße vergrößert.

A, B, C: Negativkontrolle (nur sekundär Antikörper (Cy3))

A, D, G, J, M, P, S, V, Y: Kernfärbung mit DAPI

B, E, H, K, N, Q, T, W, Z: STRA8- Antikörperfärbung (Cy3)

C, F, I, L, O, R, U, X, Ä: Überlagerung der Fluoreszenzen

In allen getesteten Zelllinien konnte eine STRA8- Expression nachgewiesen

werden. Es konnte gezeigt werden, dass es in einigen Zelllinien (ES RI Abb.7F, SSC129Sv Abb.7I) sowohl STRA8- positive und als auch STRA8negative Zellen gibt. Zudem ist deutlich zu erkennen, dass in einigen Zelllinien (SSC FVB Abb.7Ä) STRA8 in einzelnen Zellen im Zytoplasma in anderen jedoch im Kern $(\rightarrow)$ lokalisiert ist. P...= Passagenanzahl...

Die Abbildungen wurden zusammen mit Frau Dr. Nolte erstellt und sind z.T. auch in deren Dissertation (Nolte 2008) enthalten. 
Die Tatsache, dass Stra8 in allen getesteten ES- und SSC- Zelllinien nachzuweisen war, jedoch nicht in den als nicht pluripotent beschriebenen Zelllinien (Abb.1 3T3, Abb.4 MEF) führte zu der Annahme, dass Stra8 als Pluripotenz- assoziiertes Gen in pluripotenten Zelllinien fungieren könnte. Diese Annahme wurde durch die in Abbildung $7 \ddot{A}$ gezeigte Kernlokalisation in einigen Zellen verstärkt, da bis dato alle bekannten Gene, die eine Rolle bei der Pluripotenz spielen, im Kern lokalisiert sind.

Um diese Hypothese weiter zu verfolgen, wurden nun die Zelllinien ES-RI (129SV) und SSC 129SV, welche beide denselben genetischen Hintergrund haben, einer ungerichteten Differenzierung unterzogen. Die Zellen wurden hierzu 35 Tage auf mit 0,1\% Gelatine beschichteten Kulturgefäßen und unter Retinsäure (RA)- Induktion $\left(10^{-6} \mathrm{M}\right)$ kultiviert. Mit der vollständigen Ausdifferenzierung der Zellen verschwindet die Expression von Pluripotenzbzw. Pluripotenz- assozilerten Genen. Aus den Zellen wurde anschließend RNA isoliert und in cDNA umgeschrieben. Es wurde eine RT- PCR für Stra8 mit cDNA aus differenzierten und undifferenzierten Zellen durchgeführt (Abb.8). Als Positivkontrolle diente das Gen Zfp206, für das bereits gezeigt werden konnte, dass die Expression in differenzierten Zellen verschwindet (Zhang et al. 2006). 


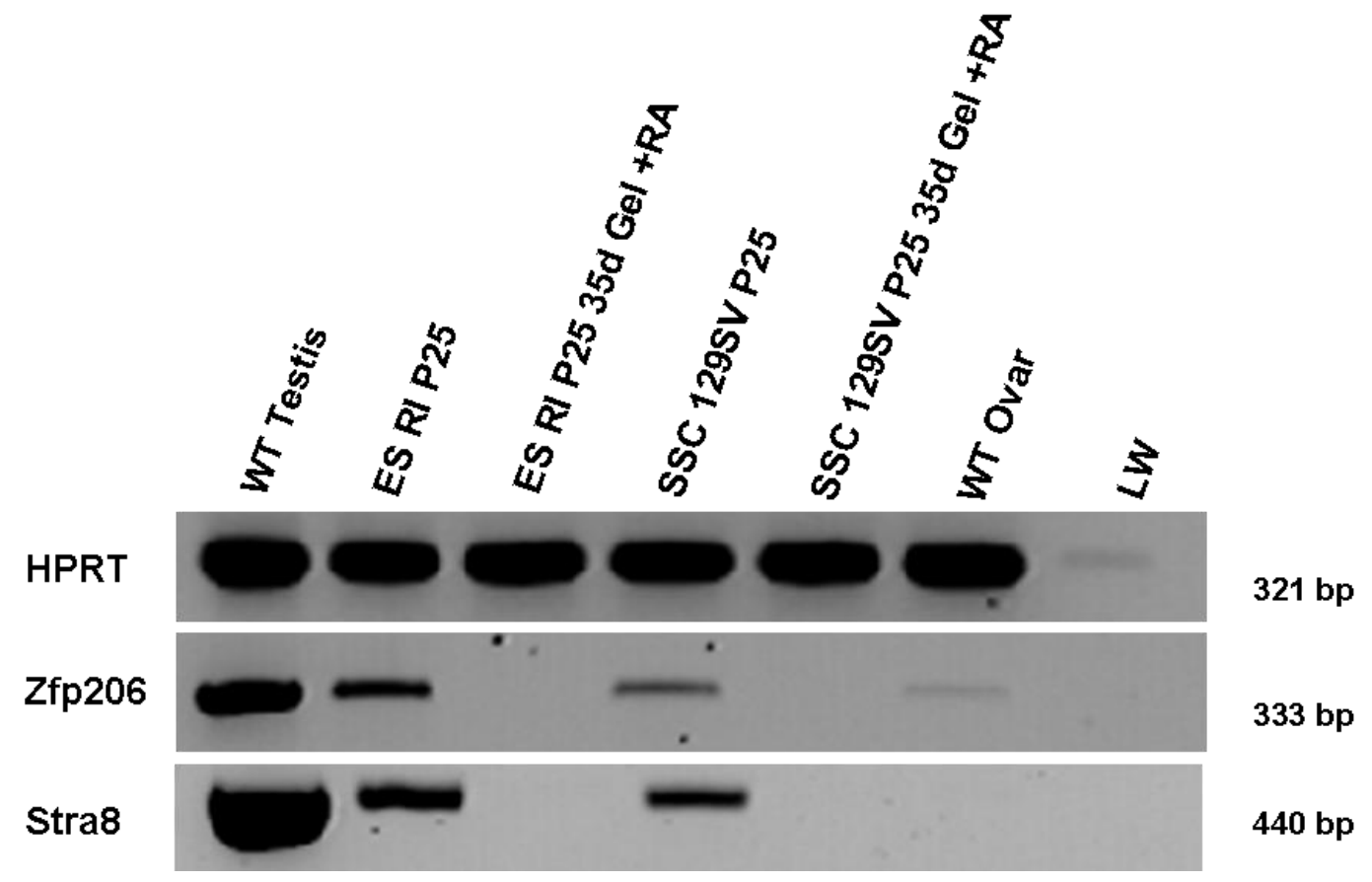

Abbildung 8: RT- PCR- Expressionsanalyse für Stra8 mit cDNA aus differenzierten und undifferenzierten Zellen

ES-RI P25 und SSC 129SV P25= Undifferenzierte Zellen $35 \mathrm{~d} \mathrm{Gel}+\mathrm{RA}=$ differenzierte Zellen; für 35 Tage auf Gelatine plus Retinsäure kultiviert

WT- Ovar= Kontrolle

$\mathrm{LW}=$ Negativkontrolle ohne Template

Die dargestellten Ergebnisse wurden gemeinsam mit Frau Dr. Nolte erarbeitet (Nolte 2008).

In den differenzierten Zellen war weder Zfp206- noch Stra8- Expression nachweisbar. Dies kann als weiterer Hinweis dafür gesehen werden, dass Stra8 ein Pluripotenz- assoziiertes Gen ist.

\subsubsection{Stra8- Expression in Embryonen}

Da Stra8 sowohl im Ovar als auch in den ES- Zelllinien (diese werden aus der inneren Zellmasse von Blastozysten isoliert) detektiert wurde, war nun von großem Interesse, ob Stra8 auch in den Präimplantationsembryonen exprimiert wird. Um dies zu untersuchen, wurde aus je 50 isolierten Embryonen verschiedener Entwicklungsstadien (unbefruchtete Oozyten bis Blastozysten) die Gesamt- RNA mit dem RNeasy Mini- Kit (Qiagen) isoliert. Die RNA wurde in CDNA umgeschrieben und zunächst eine HPRT- Kontroll- 
PCR durchgeführt (Abb.9). Zum Vergleich wurde auch die Zfp206Expression untersucht.

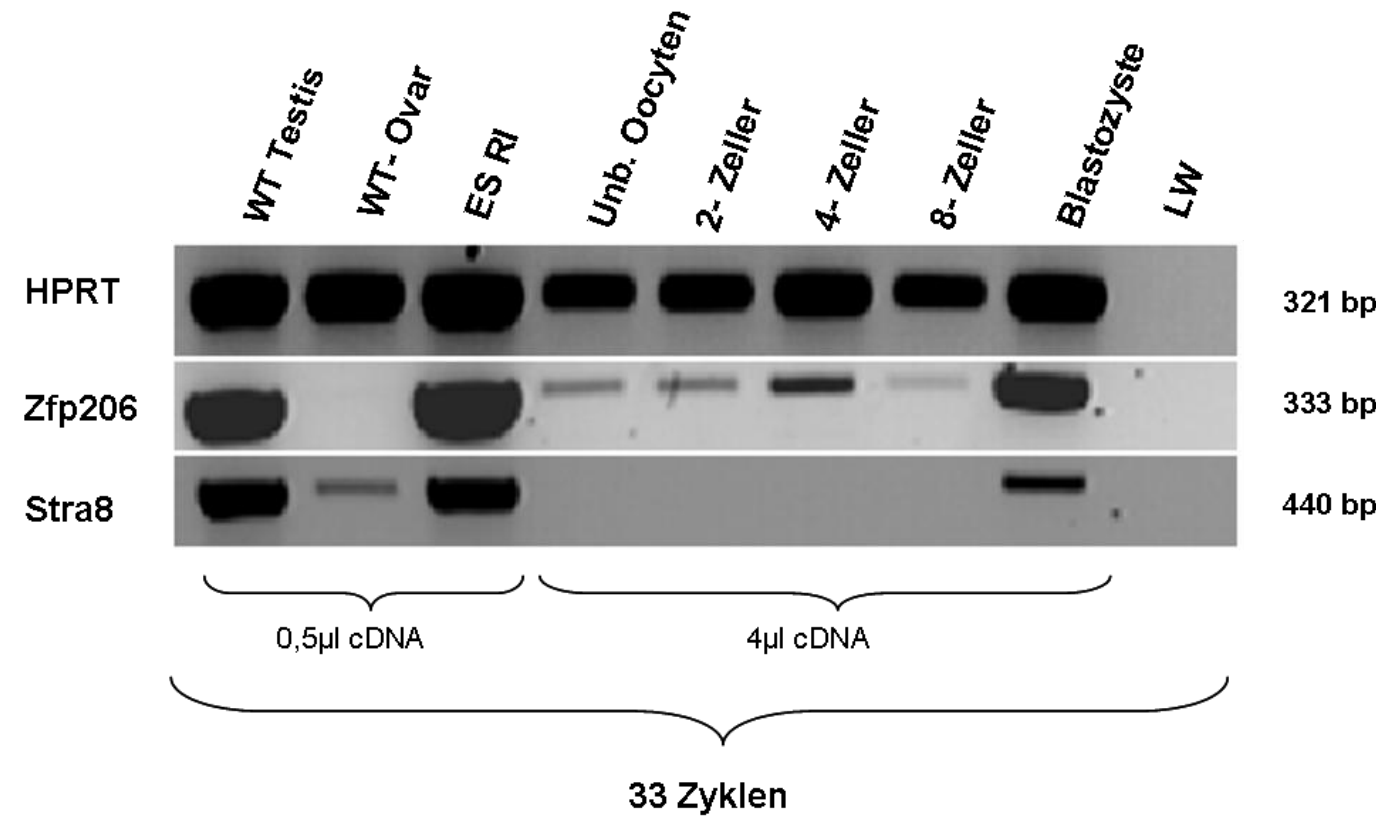

Abbildung 9: RT- PCR- Expressionsanalyse für Stra8 und Zfp206 in Embryonen (50)

Für diese RT- PCR wurde RNA aus je 50 Embryonen isoliert und komplett in cDNA umgeschrieben. Die Zykluszahl wurde von 30 auf 33 erhöht und die achtfache Menge an cDNA eingesetzt. Unter diesen Bedingungen konnte in allen Stadien Zfp206 detektiert werden. Stra8 konnte jedoch nur im Blastozystenstadium nachgewiesen werden.

WT- Testis $=$ Positivkontrolle, LW $=$ Negativkontrolle ohne Template

Da es unter den üblichen Bedingungen nicht gelang, die publizierten Daten für Zfp206 zu reproduzieren und auch keine Stra8- Expression nachweisbar war, wurde die Zykluszahl von 30 auf 33 erhöht und die achtfache Menge an cDNA eingesetzt. Unter diesen Bedingungen stimmte das Zfp206Expressionsmuster mit dem publizierten überein. In der Blastozyste konnte nun auch Stra8 detektiert werden.

Um sicherzustellen, dass die Ergebnisse nicht nur ein Artefakt waren, wurde dieser Versuch für 8- Zeller, Morulae und Blastozysten wiederholt. Diesmal wurde jedoch Gesamt- RNA aus 100 Embryonen isoliert und komplett in cDNA umgeschrieben. Unter diesen Bedingungen zeigte sich wieder das für 
Zfp206 publizierte Expressionsprofil. Stra8 konnte nun jedoch in allen getesteten Embryonalstadien nachgewiesen werden (Abb.10).

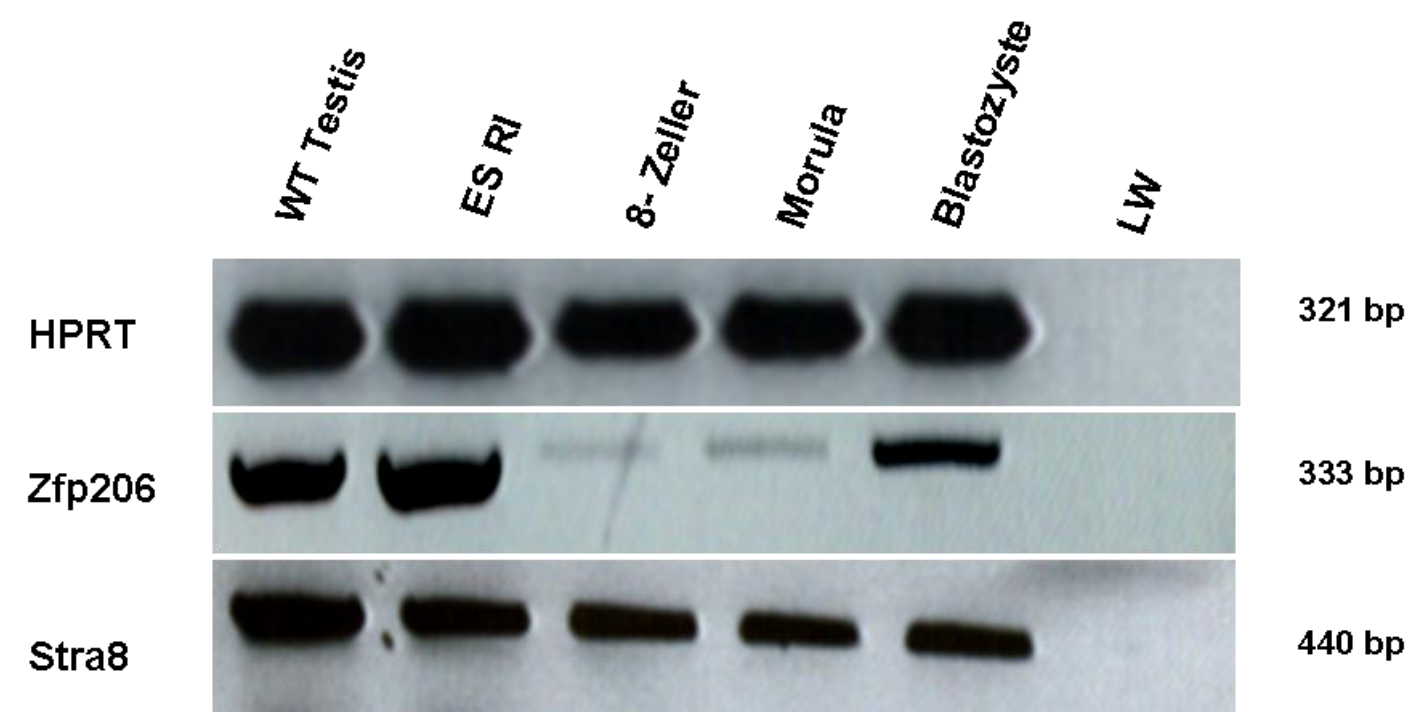

Abbildung 10: RT- PCR- Expressionsanalyse für Stra8 und Zfp206 in Embryonen (100)

Für diese RT- PCR wurde RNA aus je 100 Embryonen isoliert und komplett in cDNA umgeschrieben. Unter den gewählten Bedingungen konnte Stra8 in allen Embryonalstadien detektiert werden. Das Expressionsmuster von Zfp206 stimmt mit dem zuvor erhaltenen überein (Abb.9).

Die in den Abbildungen 9 und 10 dargestellten Ergebnisse wurden zusammen mit Frau Dr. Nolte erarbeitet (Nolte 2008).

\subsubsection{Immunhistochemischer Nachweis der STRA8- Expression in} Präimplantationsembryonen

Um die STRA8- Expression auf Proteinebene in den verschiedenen Embryonalstadien zu testen, wurden die verschiedenen Stadien (unbefruchtete Oozyte bis Blastozyste) isoliert, einer immunhistochemischen Färbung unterzogen und auf einem Hohlschliffobjektträger mikroskopiert (Abb.11). Es konnte in der unbefruchteten Oozyte und in allen Embryonalstadien STRA8 nachgewiesen werden. STRA8 war immer zytoplasmatisch lokalisiert. In der Blastozyste konnte eine Expression sowohl in den Zellen der inneren Zellmasse als auch in den Zellen des 
Trophoblasten nachgewiesen werden (Abb.11G5). In Abbildung 11 A1-5 wurde als Negativkontrolle exemplarisch auf das 8- Zellstadium nur der sekundäre Antikörper zugegeben. Stra8 konnte sowohl mittels RT- PCR als auch immunhistochemisch in allen Präimplantationsstadien nachgewiesen werden.

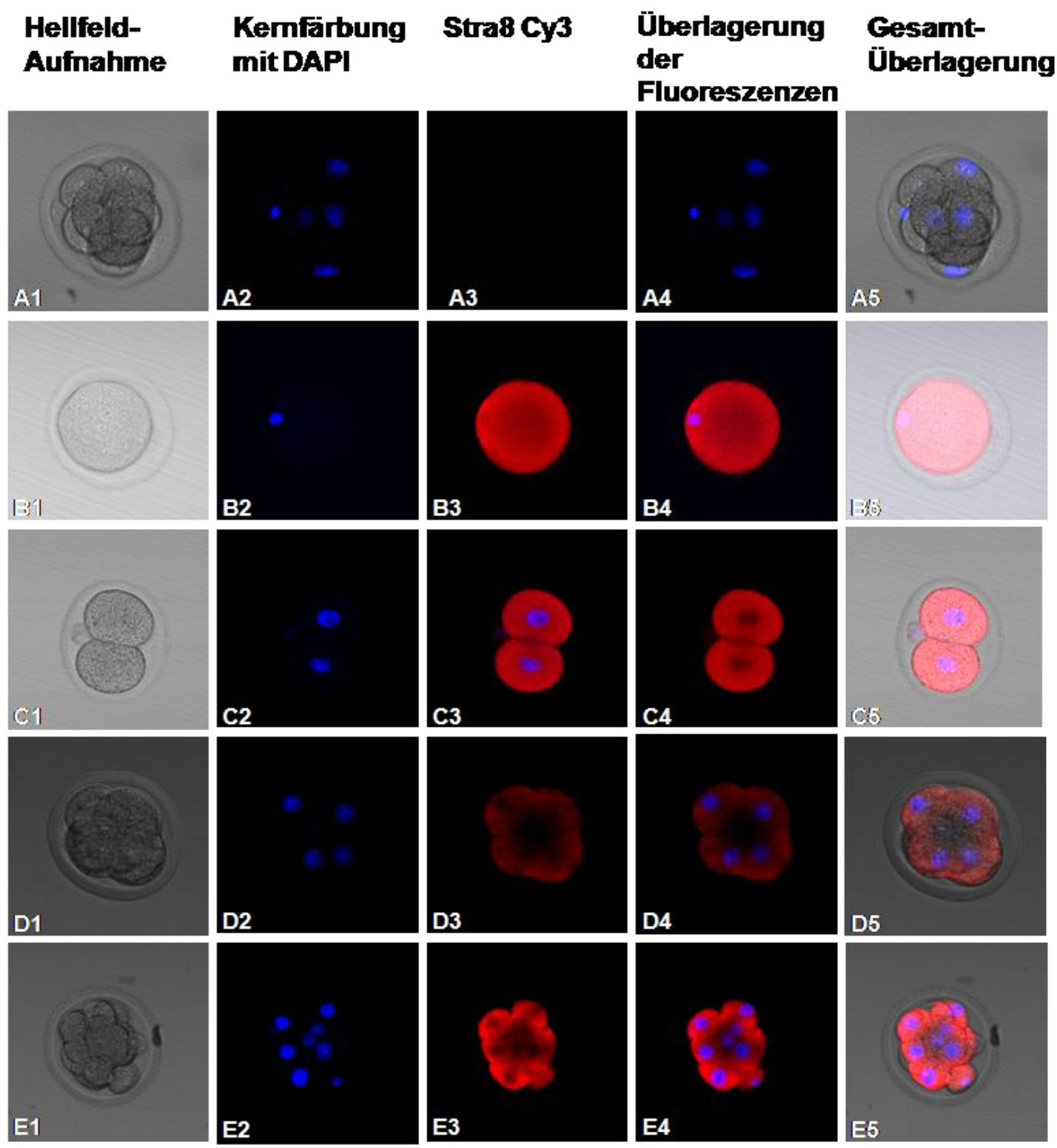



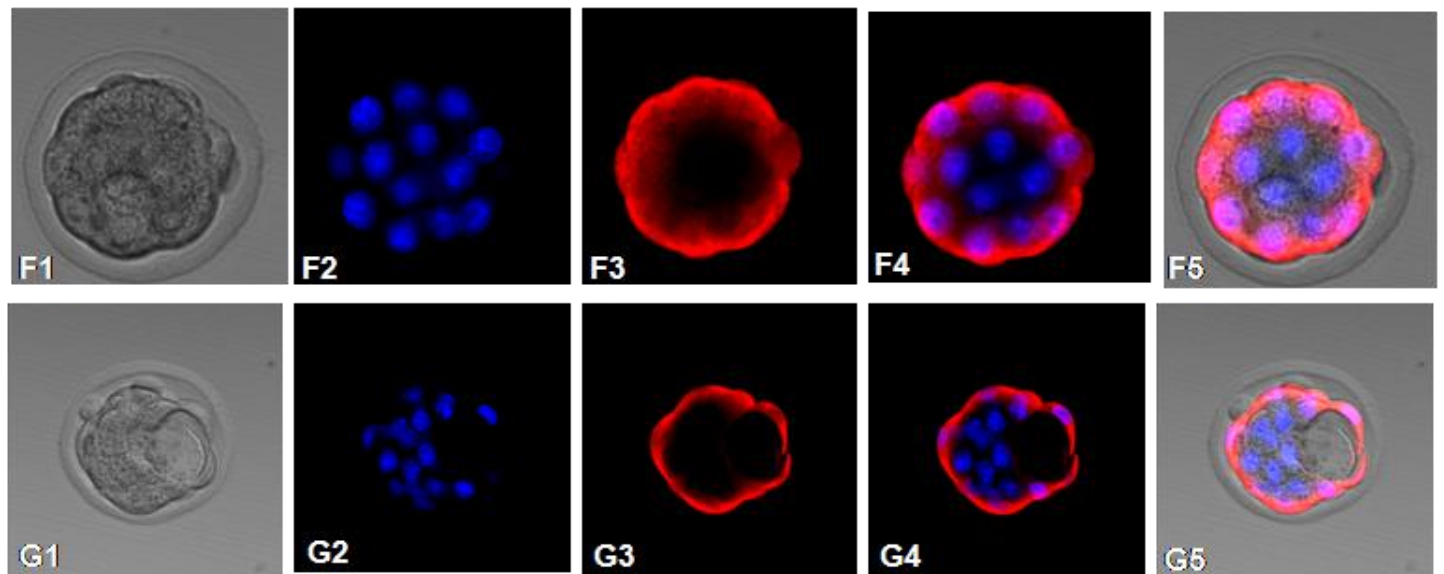

Abbildung 11: STRA8- Antikörperfärbung auf Präimplantationsembryonen

Die Bilder wurden mit einem 20er Objektiv aufgenommen und mit der zum LSM zugehörigen Software auf Bildausschnittgröße vergrößert.

A1-5: Negativkontrolle (nur sek. Antikörper) auf 8- Zellern

B1-5: Antikörperfärbung auf unbefruchteten Oozyten

C1-5: Antikörperfärbung auf 2- Zellern

D1-5: Antikörperfärbung auf 4- Zellern

E1-5: Antikörperfärbung auf 8- Zellern

F1-5: Antikörperfärbung auf Morulae

G1-5: Antikörperfärbung auf Blastozysten

Diese Antikörperfärbungen wurden gemeinsam mit Frau Dr. Nolte generiert und sind z.T. auch in der Dissertation von

Frau Dr. Nolte enthalten (Nolte 2008).

\subsection{Untersuchung der Rolle von Stra8 bei der}

\section{Pluripotenz}

$\mathrm{Da}$ in den vorherigen Versuchen gezeigt werden konnte, dass es in pluripotenten Zelllinien STRA8- positive und -negative Zellen gibt (Abb.7, DE), wurde in einem nächsten Versuchsansatz untersucht, welche Rolle die Stra8- Expression bezüglich der Pluripotenz von Stammzellen hat. Hierzu wurde die ES RI Stra8/10- Zelllinie (Diplomarbeit Nolte 2005), welche EGFP unter der Kontrolle des Stra8- Promotors exprimiert, mittels FACSortierung auf ihre EGFP- Fluoreszenz sortiert (Abb.12). Um zu untersuchen, ob die Stra8- positiven Zellen "pluripotenter" sind als die Stra8- negativen Zellen, wurden Blastozysteninjektionen zur Herstellung von Chimären durchgeführt. Es wurden zum Vergleich einmal sortierte EGFP- positive Zellen (=Stra8 positiv) und einmal unsortierte Zellen verwendet. 
DAPI
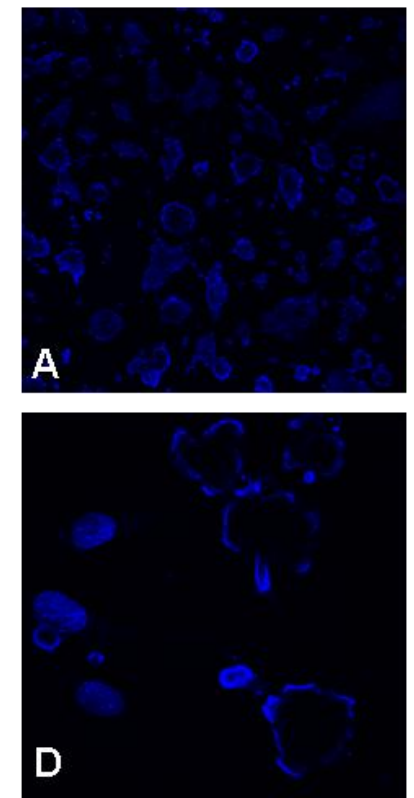

Stra8
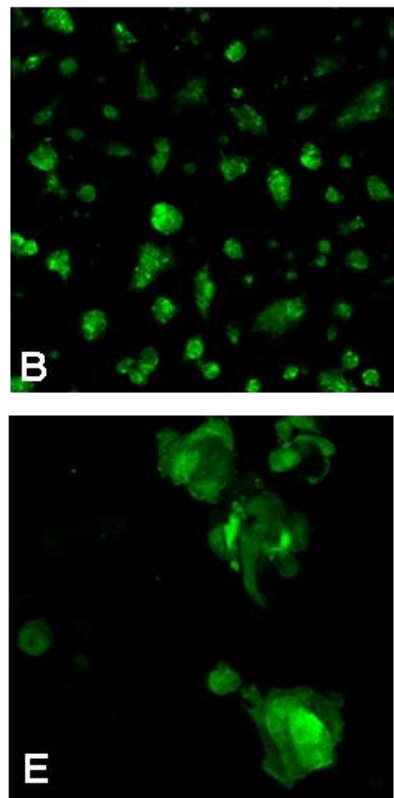

Überlagerung
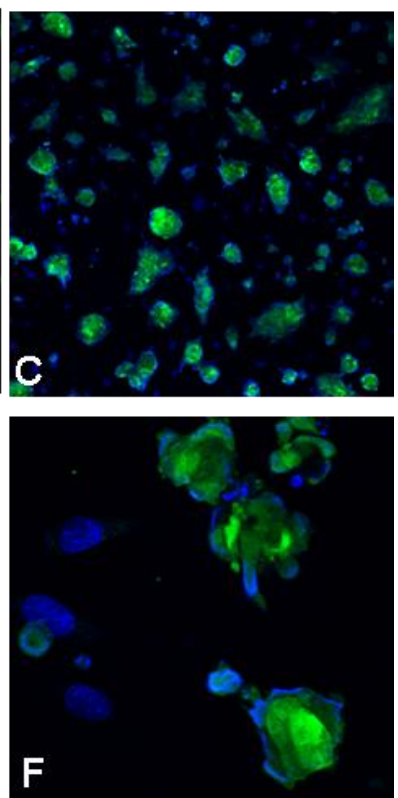

Abbildung 12: EGFP- Fluoreszenz der ES RI Stra8/10 nach FACSortierung

A-C: 200fache Vergrößerung

D-F: 400fache Vergrößerung

Die ES RI- Zellen stammten aus dem 129SV- Hintergrund, welcher eine braune Fellfarbe hat. Für die Blastozysteninjektion wurden Blastozysten aus C57BI/6- Mäusen verwendet, die eine schwarze Fellfarbe haben. Die entstandenen Chimären konnten somit anhand ihres typischen Phänotyps (braun- schwarze Fellfarbe) identifiziert werden (Abb.13).

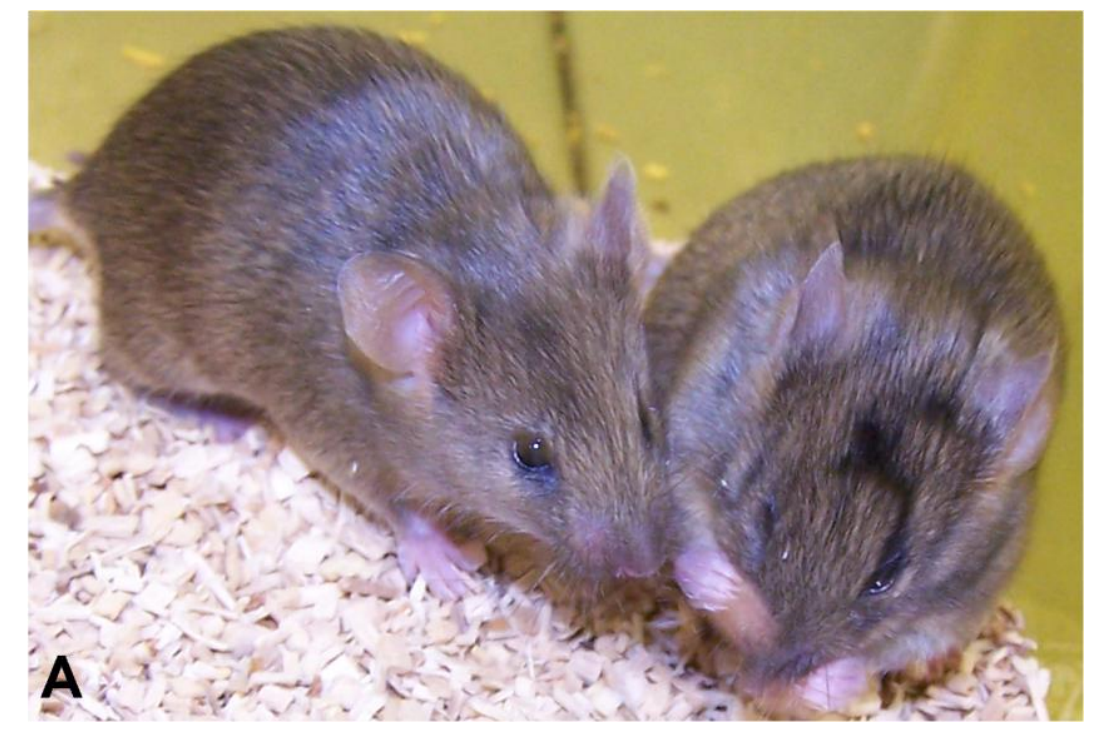




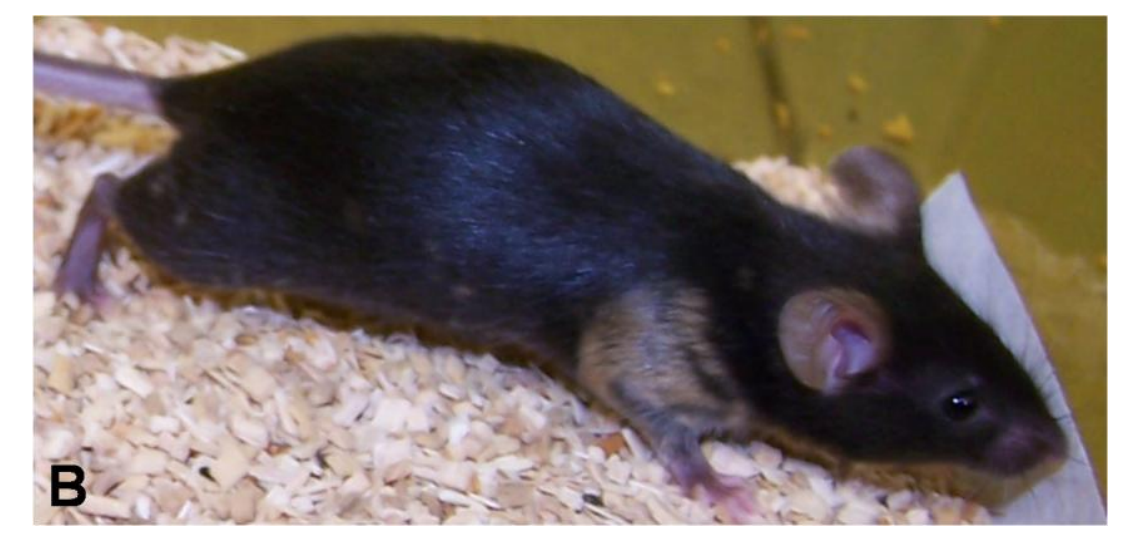

Abbildung 13: Chimären entstanden aus den EGFP+- Zellen
A: $90 \%$ ige Chimären
B: $10 \%$ ige Chimäre
Im Phänotyp zeigt sich ein schwarz- braunes Fell

Wie Tabelle 1 zeigt, erbrachten diese Experimente kein eindeutiges Ergebnis. Wären Stra8- positive Zellen tatsächlich pluripotenter, wäre zu erwarten, dass aus den Blastozysteninjektionen mit den Stra8- positiven Zellen mehr und höherprozentige Chimären hervorgehen als bei der WTKontrolle. Aus den Injektionen mit den Stra8- positiven Zellen gingen zwar zwei hochprozentige Chimären (90\%) hervor, aber die Injektion mit unsortierten Zellen erbrachte insgesamt mehr Chimären, unter denen auch eine höherprozentige war (80\%).

Tabelle 2: Ergebnisse der Blastozysteninjektionen

[Gemeinsam mit Frau Dr. Nolte erarbeitet und in deren Dissertation enthalten (Nolte 2008 S.113)]

\begin{tabular}{|l|c|c|c|}
\hline \multicolumn{1}{|c|}{ Zelllinie } & Anzahl der Embryonentransfere & Anzahl der NKO's & Chimären \\
\hline ES-RIWT & 2 & 16 & $1 \times 10 \%$ \\
& & & $2 \times 25 \%$ \\
& & & $2 \times 65 \%$ \\
& & & $1 \times 80 \%$ \\
\hline ES-RI-Stra8/10 EGFP+ & 2 & 23 & $2 \times 10 \%$ \\
& & & $2 \times 90 \%$ \\
\hline
\end{tabular}

Die Ergebnisse lassen darauf schließen, dass Stra8 zumindest keine zentrale Funktion bezüglich der Pluripotenz hat. 


\subsection{Bestimmung des prozentualen Anteils an Stra8- positiven Zellen im Testis der transgenen Stra8/EGFP- Maus}

Zur Bestimmung des prozentualen Anteils an Stra8- positiven Zellen im Testis, wurden die entstandenen hochprozentigen Stra8/EGFP- Chimären (90\%) mit Mäusen aus der C57/BI- WT- Linie verpaart. Die daraus entstandenen braunen Nachkommen wurden zunächst einer Genotypisierungs- PCR zur Identifizierung des Stra8/EGFPPromotorkonstrukts unterzogen (Beispiel in Abb.14).

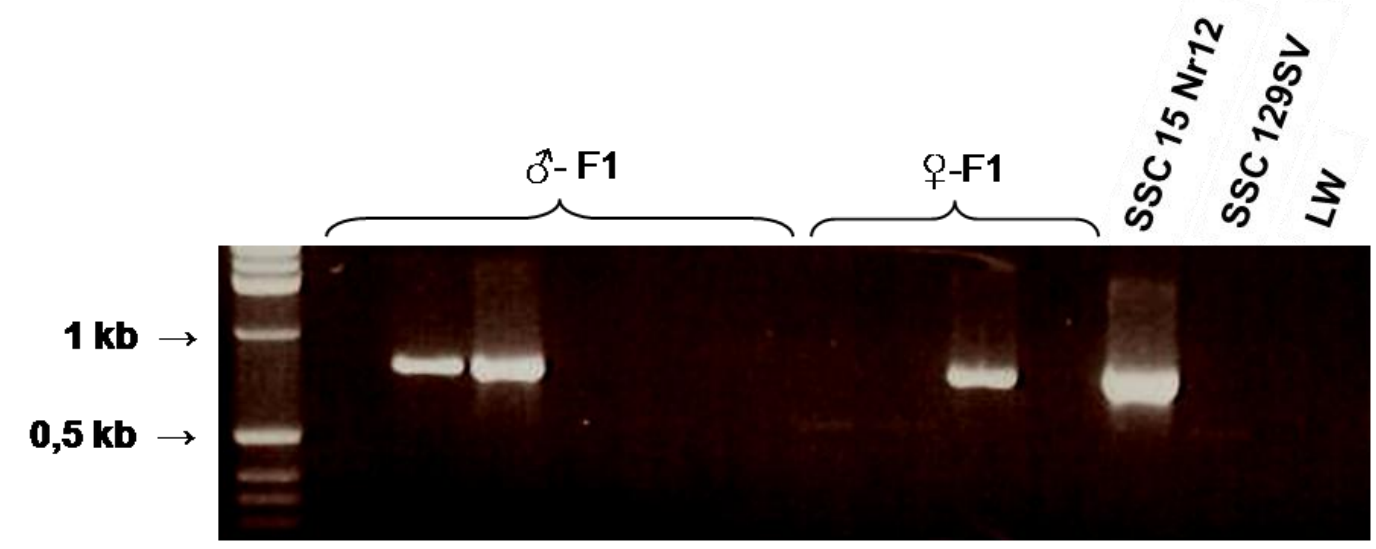

Abbildung 14: Genotypisierungs- PCR der braunen Nachkommen (F1) der Stra8/EGFP- Chimären

DNA aus sechs männlichen und vier weiblichen braunen Nachkommen. Als Kontrolle dienten die Zelllinie SSC 15 Nr.12 (positiv) und SSC 129SV (negativ).

$\mathrm{LW}=$ negativ Kontrolle ohne Template.

Anschließend wurden die Testes 14 Tage alter und adulter männlicher Stra8/EGFP- positiver- Nachkommen zu einer Einzelzell- Suspension dissoziiert und in dieser der prozentuale Anteil an Stra8/EGFP ${ }^{+}$- Zellen per FACScanning bestimmt (in Kooperation mit Prof. Dr. Dressel, Abteilung Zelluläre und Molekulare Immunologie). Es konnte gezeigt werden, dass in 14 Tage alten Testes 47,2\% und in adulten Testes 5,96\% der Zellen EGFPund damit Stra8- positiv waren (Abb.15).

Dieser Unterschied war zu erwarten, da im 14 Tage alten Testis noch kaum Spermatogenese stattfindet, und somit der prozentuale Anteil an Spermatogonien höher ist. In den vorangegangenen Versuchen konnte 
gezeigt werden, dass nur Typ A und Typ B Spermatogonien sowie präleptotäne und frühe leptotäne Spermatozyten Stra8- positiv sind (3.1.2).

A

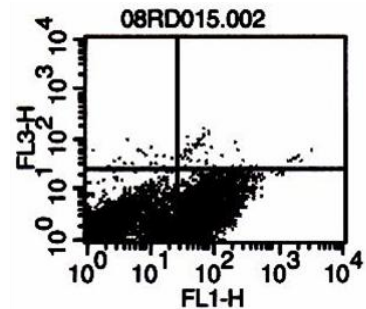

File: 08RD015.002 Sample ID: 08RD015

Tube:

Acquisition Date: 12-Mar-8 Gated Events: 7989 X Parameter. FL1-H (Log) Quad Location: 25, 25
Quadrant Statistics

Log Data Units: Linear Values Patient ID:

Panel:

Gate: G1

Total Events: 10000

Y Parameter. FL3-H (Log)

Quad Events \% Gated \% Total XMean X Geo Mean Y Mean Y Geo Mean

$\begin{array}{lrrrrrrr}\text { UL } & 18 & 0.23 & 0.18 & 7.99 & 6.33 & 47.44 & 44.66 \\ \text { UR } & 66 & 0.83 & 0.66 & 300.10 & 96.93 & 58.94 & 52.42 \\ \text { UL } & 4073 & 50.98 & 40.73 & 8.03 & 4.84 & 2.75 & 2.26 \\ \text { UR } & 3832 & 47.97 & 38.32 & 87.71 & 69.67 & 4.93 & 3.74\end{array}$

B

\begin{tabular}{|l|c|c|c|}
\hline & $\begin{array}{l}\text { Wildtyp- Hintergrund } \\
\text { (WT) }\end{array}$ & $\begin{array}{l}\text { Stra8/EGFP transgene } \\
\text { Mäuse }\end{array}$ & $\begin{array}{l}\text { Totale Anzahl } \\
\text { (Stra8/EGFP - WT) }\end{array}$ \\
\hline $\begin{array}{l}\text { 14d alter Testis } \\
\% \text { der Zellen im LR- Gate }\end{array}$ & $0.77 \%$ & $47.97 \%$ & $47.2 \%$ \\
\hline $\begin{array}{l}\text { Adulter Testis } \\
\% \text { der Zellen im LR- Gate }\end{array}$ & $0.30 \%$ & $6.26 \%$ & $5.96 \%$ \\
\hline
\end{tabular}

Abbildung 15: FACScanning für EGFP- positive Zellen aus der Testissuspension 14 Tage alter und adulter transgener Stra8/EGFP- Mäuse

A: Exemplarische Darstellung der Auswertung eines FACScanning. Testissuspension einer 14 Tage alten Stra8/EGFP- transgenen Maus. Im Gate LR befinden sich die EGFP ${ }^{+}$- Zellen (47.97\%).

B: Tabelle: Auswertung der FACSortierung. Es wurde der prozentuale Anteil der Zellen im LR- Gate von WT- Testis von denen der Stra8/EGFP- transgene Mäusen abgezogen. Damit wurde ermittelt, wie viele Testis- Zellen der transgenen Mäuse Stra8/EGFP- positiv sind.

Um zu zeigen, dass in den Stra8/EGFP- transgenen Nachkommen das Stra8-Expressionsmuster mit dem der WT- Mäuse übereinstimmt, wurde die EGFP- Fluoreszenz von 14 Tage altem Ovar und je 14 Tage altem- und adultem- Testis von Stra8/EGFP- positiven Nachkommen unter dem Mikroskop beurteilt. Wie Abbildung 16 zeigt, stimmt die EGFP- Fluoreszenz mit der STRA8- Fluoreszenz aus Versuch 3.1.2 (Abb.2) überein. 


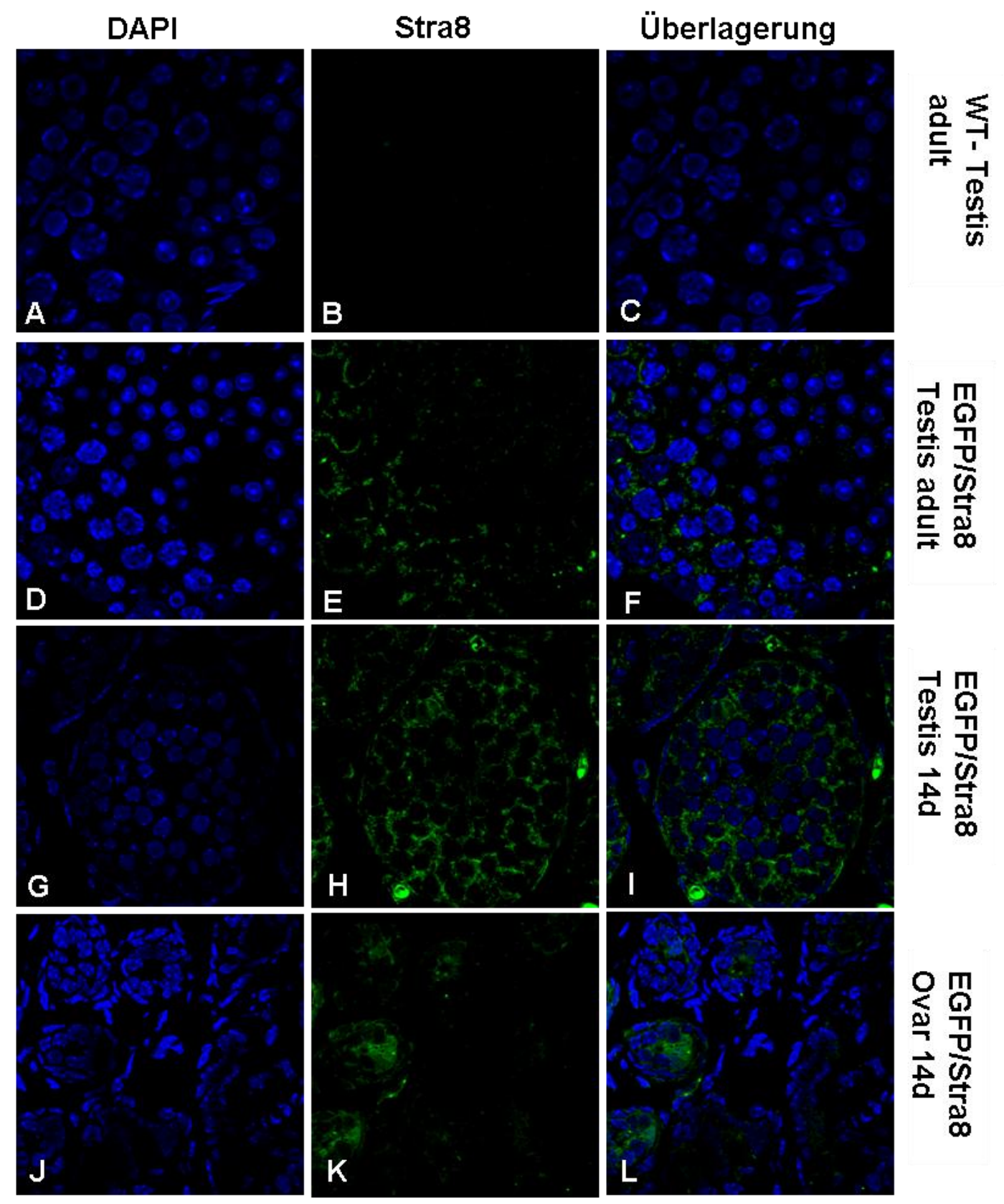

Abbildung 16: EGFP- Fluoreszenz in Testis und Ovar aus Stra8/EGFP. transgenen Mäusen

A-C: Negativ Kontrolle: EGFP- Fluoreszenz in WT- Testis 600fach Vergrößerung

D-F: Testis aus einer adulten Stra8/EGFP-Maus 400fache Vergrößerung

G-I: Testis aus einer 14d alten Stra8/EGFP- Maus 200fache Vergrößerung

J-L: Ovar aus einer 14d alten Stra8/EGFP- Maus 200fache Vergrößerung 


\subsection{Stra8- Überexpression}

In einem weiteren Versuch sollte Stra8 in jeweils einer ES- und einer SSCZelllinie stabil überexprimiert werden. Als Grundlage dieses Versuches diente die von Wang et al. (2007a) publizierte Vorgehensweise für die Überexpression von Zfp206 in einer ES- Zelllinie, durch die es gelang, Zfp206 als Pluripotenz- assoziiertes Gen zu identifizieren. Für die Überexpression von Stra8 wurde der pCMV- Myc- Vektor ausgewählt (Abb.17), da dieser den ubiquitär aktiven CMV- Promotor und einen Myc- Tag zur Detektion des Fusionsproteins enthält. Der Myc- Tag war erforderlich, um später die Expression im Western- Blot nachzuweisen, da der STRA8Antikörper im Western- Blot keine eindeutigen Ergebnisse ergibt. Zunächst musste in den pCMV- Myc- Vektor eine Hygromycin- Resistenz- Kassette integriert werden, da er keine Antibiotika- Resistenz für die Selektion in eukaryotischen Zellen besitzt. Hierzu wurde aus dem pTK- Hyg-Vektor die Hygromycin- Resistenz- Kassette durch die Blunt- End- Restriktionsenzyme Ssp1 und Fsp1 herausgeschnitten und in den durch Ssp1 liniearisierten pCMV- Myc- Vektor ligiert (Abb.17). 

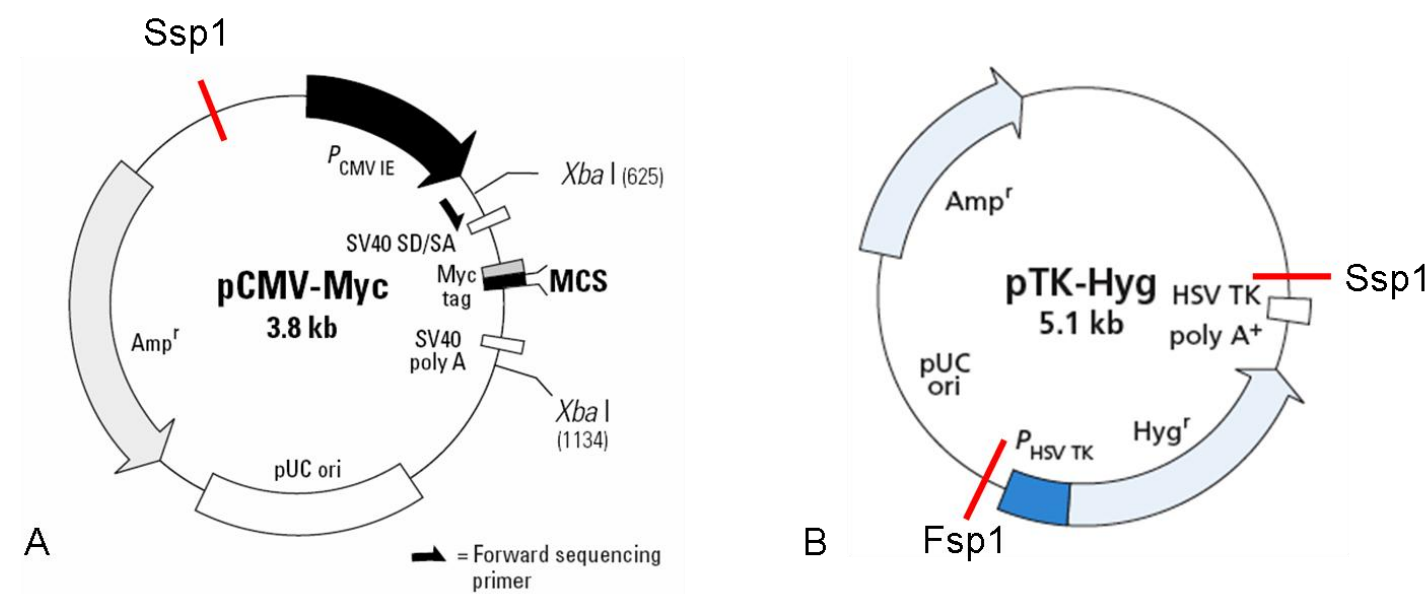

Abbildung 17: Darstellung des pCMV- Myc- Vektors und der LigationsStrategie für die Hygromycin- Resistenz- Kassette (Vektorkarten aus: www.clonetech.com)

A: pCMV- Myc- Vektor Die Expression des zu untersuchenden Gens wird von dem CMV- Promotor kontrolliert. Der Myc- Tag vor der "Multiple Cloning Site" (MCS) dient zum Detektieren der Expression im WesternBlot. Der Vektor wurde zur Integration der HygromycinResistenz- Kassette mittels Ssp1linearisiert.

B: $\quad$ pTK- Hyg- Vektor Mittels der Enzyme Fsp1 und Ssp1 wurde die Hygromycin- Resistenz- Kassette ausgeschnitten und in den PCMV- Myc- Vektor ligiert.

Um die Ligation des Stra8 Gens in die MCS des pCMV- Myc- Hyg- Vektors zu ermöglichen, wurden zunächst Primer hergestellt, die NotI- Schnittstellen an die Enden des ORF amplifizieren (Abb.18).

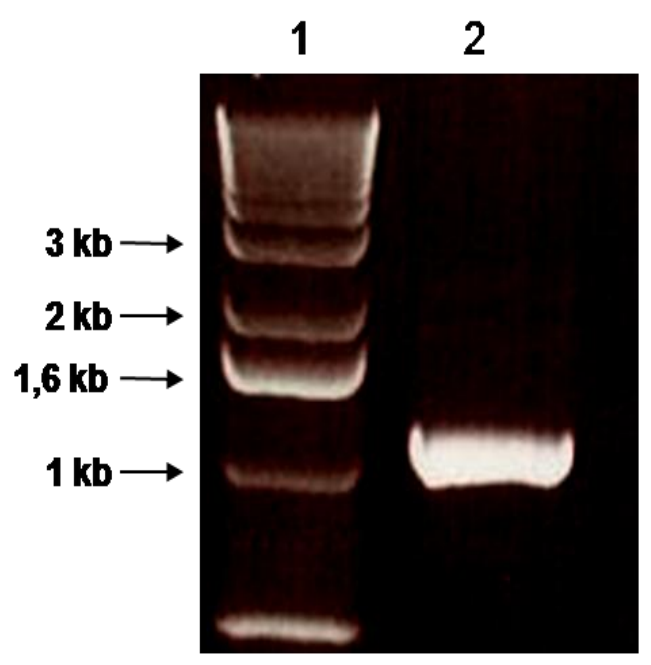

Abbildung 18:

Amplifikation des Stra8-ORFs

1: $1 \mathrm{~kb}$ - Leiter

2: Amplifikation des Stra8- ORF

$(1,2 \mathrm{~kb})$ mit den Primerpaaren ORF-

Stra8-Not I-F/ ORF-Stra8-Not I-R. 
Anschließend wurde der ORF des Stra8- Gens in den pGEM-T Easy- Vektor ligiert und der Vektor in DH5a- Bakterien transformiert. Die Kolonien, die den Vektor mit Konstrukt integriert hatten, wurden mittels NotIRestriktionsenzymverdau identifiziert (Abb.19) und einer Sequenzanalyse unterzogen.

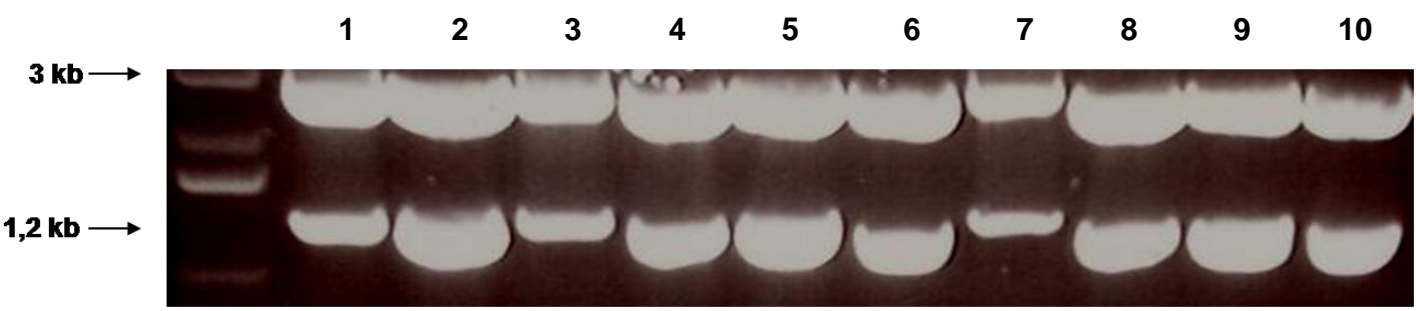

Abbildung 19: Verdau von Plasmidpräparationen von pGEM-T EasyORF- Stra8 mit dem Restriktionsenzym NotI (1-10)

Durch den Verdau mit dem Restriktionsenzym NotI wurden nach der Ligation mit dem Stra8- ORF die Konstrukttragenden Kolonien identifiziert. $\mathrm{Da}$ an den beiden Enden des ORF eine NotI- Schnittstelle amplifiziert wurde, entstehen bei dem Verdau der Konstrukt- tragenden Kolonien zwei unterschiedlich lange DNA- Fragmente, der 1,2kb Stra8- ORF und der 3kb große pGEM-T Easy- Vektor.

In dem Stra8- ORF in Kolonie 6 konnten Mutationen ausgeschlossen werden, so dass dieser als Grundlage für die Ligation in den pCMV- Myc- Hyg- Vektor genutzt werden konnte. Nach der Klonierung in den pCMV- Myc- Hyg- Vektor wurden nun erneut die Konstrukt- positiven Klone durch einen NotIRestriktionsenzymverdau ermittelt (Abb.20).

$\begin{array}{llllllllllllllllllll}1 & 2 & 3 & 4 & 5 & 6 & 7 & 8 & 9 & 10 & 11 & 12 & 13 & 14 & 15 & 16 & 17 & 18 & 19 & 20\end{array}$

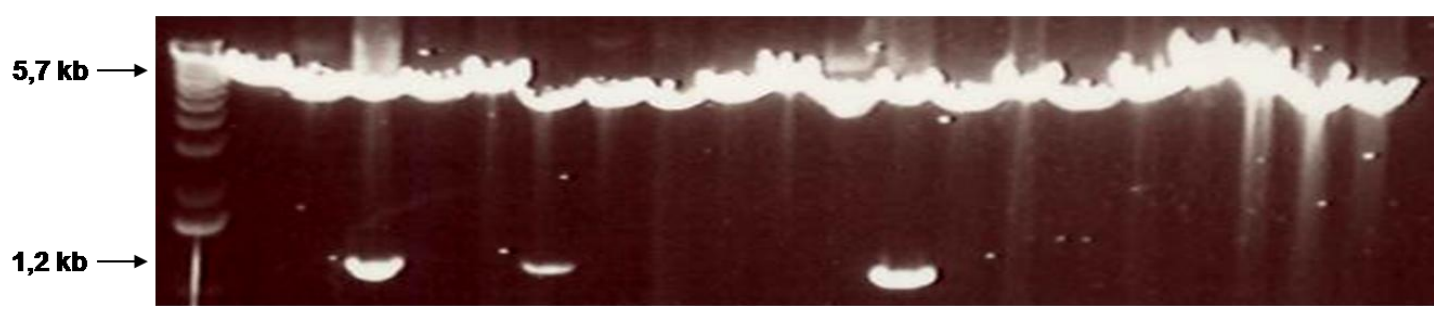

Abbildung 20: Verdau von Plasmidpräparationen von pCMV- Myc- Hyg ORF- Stra8 mit dem Restriktionsenzym NotI (1-10)

Zur Identifizierung der Stra8- ORF tragenden Kolonien wurde auch hier ein Verdau mit dem Restriktionsenzym NotI durchgeführt. Die Konstrukt- tragenden Kolonien zeigten nach dem Verdau zwei unterschiedlich lange DNAFragmente. Der 1,2kb Stra8- ORF und der 5,7kb große pCMV- Myc- Hyg- Vektor. 
Zur Kontrolle, ob der Stra8- ORF in der richtigen Orientierung in den Vektor ligiert wurde, und er weiterhin ohne Mutation ist, wurden die positiven Klone erneut einer Sequenzanalyse unterzogen. Es konnte gezeigt werden, dass die pCMV- Myc- Hyg- ORF- Stra8- Kolonie 3 den ORF in der richtigen Orientierung integriert hat und auch weiterhin keine Mutationen im Stra8ORF aufwies. Für die Transfektion in die ES- und SSC- Zelllinien wurde von der Kolonie 3 eine Endotoxin- freie Maxipräparation durchgeführt und diese anschließend steril aufgearbeitet.

Zu diesem Zeitpunkt stellte eine andere Arbeitsgruppe unseres Institutes fest, dass der CMV- Promotor in Stammzellen inaktiviert wird und somit eine stabile Überexpression in Stammzellen mit dem verwendeten pCMV- MycHyg- Vektor unwahrscheinlich ist. Der Versuch wurde an dieser Stelle abgebrochen und eine andere Strategie zur stabilen Transfektion und Überexpression mittels Retroviren erarbeitet und begonnen. 


\section{Diskussion}

Im Rahmen dieser Doktorarbeit konnte gezeigt werden, dass eine Stra8Expression im Ovar von Mäusen verschiedenen Alters (5d, 10d, 15d, 10d, adult) nachzuweisen ist. Parallel zur zytoplasmatischen Lokalisation von STRA8 im prämeiotischen Keimzellepithel in den männlichen Gonaden (Oulad Abdelghani et al. 1996; Baltus et al. 2006; Zhou et al. 2008a+b), ist STRA8 demnach auch im Ovar im Ooplasma der Oozyten lokalisiert. Die Expression ist dabei nicht auf ein bestimmtes Stadium der Follikelreifung beschränkt. Des Weiteren konnte gezeigt werden, dass auch nach der Ovulation in unbefruchteten Oozyten, aber auch in den Präimplantationsstadien der Embryonalentwicklung Stra8 auf RNA- und Proteinebene detektiert werden kann. Untersuchungen von ES- und SSC- Zelllinien hinsichtlich der Stra8 Expression zeigten, dass in allen im Institut etablierten Zellinien Stra8 zu detektieren ist. Dabei konnte auf Proteinebene gezeigt werden, dass STRA8 neben der zytoplasmatischen Lokalisation in einigen Zellen der Zelllinien nukleär lokalisiert ist. Differenzierungsversuche zeigten zudem, dass mit vollständiger Ausdifferenzierung der Zellen keine Stra8Expression in ES- und SSC- Zelllinien mehr nachzuweisen ist. Weiterführende Untersuchungen hinsichtlich einer eventuellen Rolle von Stra8 bezüglich der Pluripotenz brachten keine eindeutigen Ergebnisse. So konnte gezeigt werden, dass die Chimärenbildung nach Blastozysteninjektion mit ausschließlich Stra8 positiven ES- Zellen im Vergleich mit einer normalen Mischpopulation von ES- Zellen (die sowohl Stra8- positive als auch negative Zellen enthält), kaum einen Unterschied hervorbringt.

\subsection{Das Gen Stra8}

Das Gen Stra8 (Stimulated by retinoic acid gene 8) wurde erstmals von Bouillet et al. (1995) beschrieben. Stra8 war eines von 50 identifizierten Genen, dessen Expression unter Retinsäurebehandlung in P19 embryonalen Karzinom- Zellen induziert wird. Die cDNA von Stra8 ist 1455 bp lang. Das Gen besteht aus 9 Exons unterschiedlicher Länge und kodiert ein Protein von 393 Aminosäuren mit einem Molekulargewicht von $45 \mathrm{kDa}$. Stra8 ist bei der 
Maus auf Chromosom 6 lokalisiert. Oulad-Abdelghani et al. konnten 1996 zeigen, dass das STRA8- Protein putative Phosphorylierungsstellen für die Proteinkinase $A$ und $C$, Casein 2 und die Prolin-abhängigen Kinasen enthält. Zudem besitzt es eine 51 Aminosäuren lange Glutamin- reiche Domäne die anfangs vermuten ließ, dass das Protein STRA8 als ein Bestandteil des Zytoskeletts fungiert. Dies bestätigte sich jedoch nicht (Oulad- Abdelghani et al. 1996). Betrachtet man die Proteinstruktur, so fällt auf, dass das STRA8Protein eine Helix- loop- Helix- Domäne enthält, welche charakteristisch für Proteine ist, die an DNA binden können.

Im humanen Genom ist es Miyamoto et al. (2002) gelungen, ein Ortholog zum Stra8- Gen zu identifizieren. Es ist auf dem Chromosom 7 lokalisiert und enthält ebenfalls 9 Exons. Das kodierte Protein besteht jedoch nur aus 330 Aminosäuren und enthält keine Glutamin- reiche Domäne. Analog zum MausStra8 ist seine Expression auf den Testis beschränkt.

\subsection{Stra8- Expressionsmuster und seine Rolle in der Meiose}

Stra8 wurde 1996 von Oulad- Abdelghani et al. als Testis- spezifisches Gen beschrieben, welches auf die prämeiotischen Stadien der Spermatogenese beschränkt ist. Er zeigte, dass schon in den Embryonalstadien 12,5 bis 16,5 dpc in den männlichen Gonadenanlagen eine Stra8- Expression zu detektieren ist. Dies wurde in unserer Arbeitsgruppe im Rahmen einer Doktorarbeit bestätigt (Jaroszynski 2005). Weiterführende Untersuchungen bezüglich des Stra8- Expressionsmusters zeigten jedoch, dass die Stra8 Expression nicht nur auf den Testis beschränkt ist. So zeigte Sapin et al. (1999), dass auch in so genannten "Giant"-Zellen des Trophoblasten im Embryonalstadium 10,5-15,5dpc eine Stra8 Expression nachzuweisen ist. Ergänzend zu der von Menke et al. (2003) und Zhou et al. (2008a) nachgewiesenen Stra8- Expression in Ovarien in verschiedenen Embryonalstadien, konnte in der vorgelegten Arbeit eine Stra8- Expression in Oozyten auch noch post partum, auf RNA- als auch auf Proteinebene, nachgewiesen werden. Über die Funktion von Stra8 in der Oogenese ist nur 
wenig bekannt. Die Ergebnisse von Baltus et al. (2006) weisen auf eine wichtige Funktion von Stra8 in der männlichen als auch in der weiblichen Meiose hin. Die Autoren konnten zeigen, dass homozygote Stra8- Knockout- Mäuse beider Geschlechter infertil sind. Die Infertilität ist auf den Meiosearrest der Keimzellen zurückzuführen.

Nayernia et al. (2004) nutzten die Stra8- Expression zur Gewinnung von männlichen Keimzellen aus der pluripotenten F9 Zellinie (Teratokarzinom Zellen). Die Stra8- Expression sollte als Marker für den Übertritt in die frühen prämeiotische Phasen dienen und eine Isolierung dieser Zellen ermöglichen. Hierzu wurde zunächst eine Stra8/ EGFP- transgene F9- Zellinie generiert, die unter dem 1,4 kb-Stra8- Promotor EGFP (Enhanced Green Fluorescence Protein) exprimiert. Die transfizierten Zellen zeigten keine EGFPFluoreszenz und somit keine Stra8- Expression. Erst nach Retinsäureinduktion zeigte sich ein moderater Anteil an EGFPexprimierenden Zellen ( 42\%), der durch weitere 2- monatige Kultur der EGFP $^{+}$- Zellen auf $86 \%$ gesteigert werden konnte. Mittels FACSortierung konnten die Stra8- EGFP- positiven Zellen isoliert werden. Eine nähere Charakterisierung der isolierten Zellen zeigte, dass es sich wahrscheinlich um spermatogoniale Stammzellen, undifferenzierte und differenzierte Typ A und Typ B Spermatogonien handelt. Dies war zu erwarten, da bekannt ist, dass Stra8 in diesen Zellen exprimiert wird (Oulad-Abdelghani et al. 1996; Baltus et al. 2006). Nach Transplantation der sortierten Stra8- EGFPpositiven F9- Zellen (auch SSC1 genannt) in die Tubuli seminiferi von männlichen Mäusen, deren Keimzellen vorher zerstört wurden, differenzierten sie weiter zu haploiden Keimzellen. In den Spermien dieser Mäuse konnte das transgene Allel nachgewiesen werden. Nayernia et al. (2006) haben mit Hilfe dieser Strategie, auch aus ES- Zellen haploide Keimzellen generiert. Diese nutzten sie zur Befruchtung von Oozyten mittels ICSI (intrazytoplasmatische Spermieninjektion). Nach der Entwicklung von Zwei- Zell- Stadien wurden die Embryonen in den Uterus pseudoschwangerer Mäuse transferiert. Es kam zur Geburt von lebensfähigen Mäusen. 
Die erfolgreiche Generierung von männlichen haploiden Keimzellen aus pluripotenten F9- und ES- Zellen mittels der Stra8- Expression unterstützt die Annahme, dass Stra8 als ein Marker der frühen Phase der Meiose genutzt werden kann.

\subsection{Stra8- Expression in pluripotenten Zellen}

Als pluripotent bezeichnet man Zellen, die in der Lage sind sowohl in vivo als auch in vitro in Zellen aller drei Keimblätter (Mesoderm, Ektoderm, Endoderm) zu differenzieren. Sie sind jedoch im Gegensatz zu totipotenten Zellen nicht in der Lage, einen lebensfähigen Organismus zu bilden. Zu den pluripotenten Zellen gehören ESCs (Embryonic Stem Cells), EGCs (Embryonic Germ Cells), Teratokarzinom- Zellen und maGSCs (multipotent adult Germline Stem Cells). Es gibt Hinweise dafür, dass Stra8 neben der Rolle in der Meiose noch weitere Funktionen hat, welche in Verbindung mit den pluripotenten Eigenschaften von Zellen stehen müssen. So wurde der aktive Stra8- Promotor erfolgreich zur Gewinnung von pluripotenten maGSCs aus Testes genutzt (Guan et al. 2006). Diese sind in der Lage, in Zellen aller drei Keimblätter zu differenzieren. Des Weiteren konnte in der vorgelegten Arbeit gezeigt werden, dass Stra8 sowohl in den verschiedenen ES- Zelllinien als auch in den maGSCs (also den SSC- Zelllinien) zu detektieren ist. Wäre Stra8 lediglich ein prämeiotischer Marker, so wäre zu erwarten, dass pluripotente Zellen die Stra8- Expression verlieren oder zu haploiden Zellen differenzieren. Auch nach mehreren Passagen exprimieren diese Zellen neben den Pluripotenzgenen (Oct3/4, Nanog, Utf1, Esg1, Rex1) jedoch weiterhin Stra8 und behalten ihre pluripotenten Eigenschaften bei. In den Differenzierungsversuchen von SSC- Zelllinien sowie ES- Zelllinien verschwand hingegen die Stra8- Expression, wie auch für andere Pluripotenzgene beschrieben.

Zudem konnte in der vorgelegten Arbeit gezeigt werden, dass auch in den frühen Embryonalstadien, in denen die Zellen noch ein pluri- und am Anfang sogar ein totipotentes Differenzierungspotential aufweisen, Stra8 exprimiert wird. Somit fungiert Stra8 nicht nur als prämeiotischer Marker. Da 
nachgewiesen werden konnte, dass das STRA8- Protein nicht nur zytoplasmatisch, sondern auch zum Teil intranukleär lokalisiert ist, stellt sich die Frage, ob STRA8 eine regulatorische Funktion in der Genexpression der pluripotenten Zellen hat. Für diese Theorie spricht auch die Proteinstruktur von STRA8 mit einer "Helix- loop- Helix" (HLH)- Domäne. Diese ist charakteristisch für Proteine, die an DNA binden. Die von Tedesco et al. (2009) veröffentlichte Arbeit bestätigte diese Vermutung. Die Autoren untersuchten den "shuttle" von STRA8 zwischen Zytoplasma und Nukleus. Im Rahmen der Arbeit konnten die Autoren zeigen, dass das STRA8- Protein in der HLH- Domäne ein "nuclear localisation signal" (NLS) hat und sich downstream davon drei "nuclear export signals" (NES) befinden. Eine Funktion der NLS und der NES2 konnte experimentell bestätigt werden. Für NES1 und NES3 liegen keine Daten vor. Es konnte also gezeigt werden, dass STRA8 aktiv in den Nukleus transportiert wird, an DNA bindet und Transkriptionsprozesse aktiviert (Abb.21).

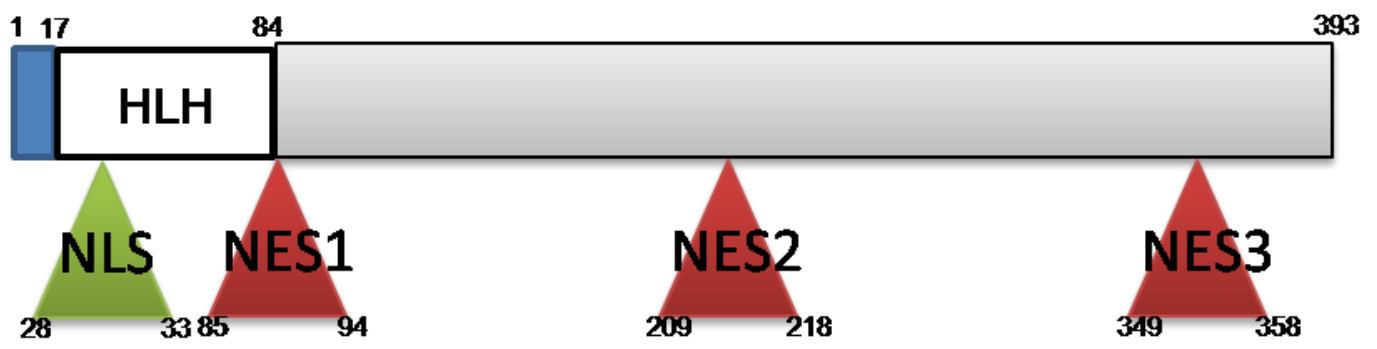

\section{Abbildung 21: Struktur des STRA8- Proteins \\ (modifiziert nach Tedesco et al. 2009) \\ NLS= "nuclear localisation signal" \\ NES= "nuclear export signal"}

Dennoch kann Stra8 keine Schlüsselfunktion hinsichtlich der pluripotenten Eigenschaften von Zellen haben. Wie die von Baltus et al. (2006) veröffentlichten Daten zeigen, sind Stra8- Knock- out- Mäuse nicht letal. Die Stra8- Knock- out- Mäuse zeigten außer Infertilität keine phänotypischen Anomalien. Auch die im Rahmen dieser Arbeit erhaltenen Ergebnisse lassen darauf schließen, dass Stra8 keinen wesentlichen Einfluss auf die pluripotenten Eigenschaften von ES- Zellen hat. Wäre dies der Fall, so hätte die Blastozysteninjektion mit Stra8- positiven ES- Zellen, im Vergleich mit 
einer Mischpopulation von Stra8- positiven und -negativen ES- Zellen, ein eindeutigeres Ergebnis hinsichtlich der Chimärenbildung hervorbringen müssen.

Für weiterführende Untersuchungen hinsichtlich der Stra8 Funktion in pluripotenten Zellen wurde in unserer Arbeitsgruppe ein Stra8- Knock- downModell etabliert. Es ist gelungen mittels synthetisch hergestellter siRNA die Stra8- Expression in pluripotenten Zellen herunterzuregulieren. Expressionsanalysen dieser Zellen haben eine Hochregulation der Pluripotenzgene Nanog, Oct3/4, Klf4 und Zfp206 ergeben. Frühe Markergene der drei Keimblätter werden hingegen geringer exprimiert. Stra8 steht demnach tatsächlich im Zusammenhang mit den pluripotenten Eigenschaften von Zellen. Anders als anfangs vermutet, scheint die Stra8- Expression jedoch eher Einfluss auf die Differenzierungsoptionen von pluripotenten Zellen zu haben.

\subsection{Perspektiven}

Durch diese Arbeit konnte die Rolle von Stra8 als Marker der Meiose, auch in den weiblichen Keimzellen, untermauert werden. Die durchgeführten Untersuchungen hinsichtlich weiterer Funktionen von Stra8, speziell in pluripotenten Zellen, lassen dennoch keine eindeutigen Schlüsse zu. Weiteren Aufschluss über die Stra8- Funktion in pluripotenten Zellen wird wohl der schon begonnene erneute Versuch einer stabilen Stra8Überexpression bringen. Analog $z u$ den von Wang et al. $(2007 a+b)$ durchgeführten Untersuchungen über Zfp206 sollen Expressionsstudien mit den Stra8- überexprimierenden pluripotenten Zellen durchgeführt werden. In diesen soll speziell auf die Expression von Pluripotenzgenen, aber auch auf Gene zur Differenzierung in Mesoderm, Ektoderm und Endoderm eingegangen werden. Erste Ergebnisse zeigen, dass es bei einer stabilen Überexpression von Stra8 (2fach) zu einer Herunterregulierung der Expression der Pluripotenzgene kommt. Die Expression verschiedener Differenzierungsmarker lässt vermuten, dass die Zellen durch die Überexpression von Stra8 in Richtung Mesoderm differenzieren. Weitere 
Versuche bezüglich des Differenzierungsverhaltens dieser Zellen sollen darüber Aufschluss geben. Insgesamt spricht aber auch dieses Ergebnis für die Theorie, dass Stra8 in den pluripotenten Zellen tatsächlich eine Funktion erfüllt und seine Expression im Zusammenhang mit den pluripotenten Eigenschaften der Zellen steht bzw. die Differenzierung von pluripotenten Zellen u.a. durch Stra8 kontrolliert wird. In weiteren Versuchen soll nun überprüft werden, wie sich Zellen, in denen Stra8 ausgeschaltet wurde, während der Differenzierung verhalten.

$\mathrm{Da}$ in dieser Arbeit gezeigt werden konnte, dass sowohl in den unbefruchteten Oozyten als auch in den verschiedenen Embryonalstadien Stra8 auf Protein und mRNA Ebene nachzuweisen ist, liegt die Vermutung nahe, dass Stra8 auch eine Rolle während der frühen Embryonalentwicklung hat. Die ersten zwei bis vier Teilungen der Zygote werden durch maternale Transkriptionsfaktoren reguliert (Übersicht in Hardy und Spanos 2002), da sich die Zygote bis zu diesem Zeitpunkt in einer transkriptionellen Inaktivität befindet. Stra8 könnte demnach als maternaler Transkriptionsfaktor dienen. Da Stra8 jedoch bis zum Stadium der Blastozyste nachgewiesen werden konnte, muss davon ausgegangen werden, dass es zu einer Stra8Genaktivierung auch in der frühen Embryogenese kommt. 


\section{Zusammenfassung}

In der vorliegenden Arbeit wurde das Stra8 (Stimulated by retinoic acid gene 8)- Gen hinsichtlich seines Expressionsmusters und seiner Rolle in pluripotenten Zellen genauer untersucht. Es konnte zu dem schon bekannten Expressionsmuster im Testis auch eine Stra8- Expression im Ovar, sowohl auf RNA- als auch auf Proteinebene, nachgewiesen werden. Anders als im Testis konnte Stra8 im Ovar jedoch in allen Oozyten der verschiedenen Entwicklungsstadien der Oogenese immunhistologisch detektiert werden. Bekannt war eine Stra8- Expression während der Oogenese bis dato nur in Mäuseembryonen (Menke et al. 2003; Zhou et al. 2008), jedoch nicht während der Oogenese post partum. Ob Stra8 als maternaler Transkriptionsfaktor dient oder Einfluss auf die Oogenese auch noch post partum hat, lässt sich noch nicht sagen. Die in dieser Arbeit nachgewiesene Stra8- Expression in verschiedenen Stadien von Präimplantationsembryonen, auch schon im Zwei- Zell- Stadium, spricht für die These, dass Stra8 als maternaler Transkriptionsfaktor dient.

Des Weiteren konnte Stra8 in verschiedenen ES- und SSC- Zelllinien auf RNA- und Proteinebene detektiert werden. Von besonderem Interesse ist die Tatsache, dass STRA8 in diesen Zellen zum Teil zytoplasmatisch, aber auch intranukleär lokalisiert ist. Parallel zu der vorliegenden Arbeit wurde der "shuttle" von STRA8 zwischen Kern und Zytoplasma auch von Tedesco et al. (2009) beschrieben und genauer untersucht. Die Proteinstruktur von STRA8, sowie die Ergebnisse von Tedesco et al. (2009) weisen darauf hin, dass STRA8 in pluripotenten Zellen aktiv in den Nukleus transportiert wird, an DNA bindet und Transkriptionsprozesse aktiviert. Es liegt demnach nahe anzunehmen, dass Stra8 eine Rolle bei der Differenzierung von pluripotenten Zellen haben könnte. Die Untersuchungen der vorliegenden Arbeit lassen jedoch keinen näheren Schluss zu, welche Rolle Stra8 in pluripotenten Zellen genau hat. Es konnte gezeigt werden, dass die Stra8Expression synchron zu der Expression von Pluripotenzgenen auch nach mehreren Passagen noch $\mathrm{zu}$ detektieren ist und bei Differenzierungsversuchen verschwindet. Um zu untersuchen, ob Stra8- 
positive- ES- Zellen ein höheres oder niedrigeres Pluripotenz- Potenzial haben als Stra8- negative, wurden Blastozysteninjektionen mit Stra8positiven ES- Zellen im Vergleich mit einer Mischpopulation von Stra8positiven und -negativen ES-Zellen durchgeführt. Die Ergebnisse lassen darauf schließen, dass Stra8 keinen wesentlichen Einfluss auf die pluripotenten Eigenschaften von ES- Zellen hat, da ansonsten ein eindeutigeres Ergebnis hinsichtlich der Chimärenbildung zu erwarten gewesen wäre. Um die Rolle von Stra8 in pluripotenten Zellen genauer zu verifizieren, sollten im Rahmen dieser Arbeit ES- Zellen etabliert und untersucht werden, die Stra8 stabil überexprimieren. Mit der erarbeiteten Strategie konnte dieser Versuch jedoch nicht durchgeführt werden und wurde abgebrochen. Eine andere Strategie zur stabilen Transfektion und Überexpression wurde erarbeitet und begonnen. 


\section{Literaturverzeichnis}

Adham IM, Nayernia K, Engel W. (1997): Spermatozoa lacking Acrosin protein show delayed fertilisation. Mol Rep Dev 46: 370-376.

Altschul SF, Gish W, Miller W, Myers EW, Lipman DJ (1990): Basic local alignment search tool. J Mol Biol 215 (3): 403-410.

Baltus AE, Menke DB, Hu YC, Goodheart ML, Carpenter AE, de Rooij DG, Page DC (2006): In germ cells of mouse embryonic ovaries, the decision to enter meiosis precedes premeiotic DNA replication. Nat Genet $\underline{38}$ (12): 1430-1434.

Beddington RS, Robertson EJ (1989): An assessment of the developmental potential of embryonic stem cells in the midgestation mouse embryo. Development 105 (4): 733-737.

Birnboim HC, Doly J (1979): A rapid alkaline extraction procedure for screening recombinant plasmid DNA. Nucleic Acids Res $\underline{7}$ (6): 1513-1523.

Bouillet $\mathbf{P}$, Chazaud C, Oulad-Abdelghani $\mathbf{M}$, Dollé $\mathbf{P}$, Chambon $\mathbf{P}$ (1995): Sequence and expression pattern of the Stra7 (Gbx-2) homeoboxcontaining gene induced by retinoic acid in P19 embryonal carcinoma cells. Dev Dyn 204 (4): 372-382.

Chambers I, Colby D, Robertson M, Nichols J, Lee S, Tweedie S, Smith A (2003): Functional expression cloning of Nanog, a pluripotency sustaining factor in embryonic stem cells. Cell 113 (5): 643-655.

Chien A, Edgar DB, Trela JM (1976): Deoxyribonucleic acid polymerase from the extreme thermophile Thermus aquaticus. J Bacteriol $\underline{7}$ (3): 15501557. 
Chiquoine AD (1954): The identification, origin, and migration of the primordial germ cells in the mouse embryo. Anat Rec 118 (2):135-146.

Clark AT, Bodnar MS, Fox M, Rodriquez RT, Abeyta MJ, Firpo MT, Pera RA (2004): Spontaneous differentiation of germ cells from human embryonic stem cells in vitro. Hum Mol Genet 13 (7): 727-739.

Clark JM (1988): Novel non-templated nucleotide addition reactions catalyzed by procaryotic and eucaryotic DNA polymerases. Nucleic Acids Res 16 (20): 9677-9686.

Denhardt DT (1966): A membrane-filter technique for the detection of complementary DNA. Biochem Biophys Res Commun $\underline{23}$ (5): 641-646.

Dihazi H, Dihazi GH, Nolte J, Meyer S, Jahn O, Müller GA, Engel W (2009): Multipotent adult germline stem cells and embryonic stem cells: comparative proteomic approach. J Proteome Res $\underline{8}$ (12): 5497-5510.

Dressel R, Guan K, Nolte J, Elsner L, Monecke S, Nayernia K, Hasenfuss G, Engel W (2009): Multipotent adult germ-line stem cells, like other pluripotent stem cells, can be killed by cytotoxic $T$ lymphocytes despite low expression of major histocompatibility complex class I molecules. Biol Direct 4 $\mathbf{3} 3$.

Dressel R, Nolte J, Elsner L, Novota P, Guan K, Streckfuss-Bömeke K, Hasenfuss G, Jaenisch R, Engel W (2010): Pluripotent stem cells are highly susceptible targets for syngeneic, allogeneic, and xenogeneic natural killer cells. FASEB J [Epub ahead of print]

Feinberg AP, Vogelstein B (1983): A technique for radiolabeling DNA restriction endonuclease fragments to high specific activity. Anal Biochem 132 (1): 6-13. 
Guan K, Nayernia K, Maier LS, Wagner S, Dressel R, Lee JH, Nolte J, Wolf F, Li M, Engel W, Hasenfuss G (2006): Pluripotency of spermatogonial stem cells from adult mouse testis. Nature $\underline{440}$ (7088): 1199-1203.

Hanahan D (1983): Studies on transformation of Escherichia coli with plasmids. J Mol Biol 166 (4): 557-580.

Hardy K and Spanos S (2002): Growth factor expression and function in the human and mouse preimplantation embryo. J Endocrinol Rev 172 (2): 221-236.

Hodge R (1994):Reparation of RNA gel blots. Methods Mol Biol 28: 49-54.

Horie K, Takakura K, Taii S, Narimoto K, Noda Y, Nishikawa S, Nakayama H, Fujita J, Mori T (1991): The expression of c-kit protein during oogenesis and early embryonic development. Biol Reprod 45 (4): 547-552.

Jaroszynski L : Expression and functional analysis of Tex18 and Stra8 genes in male germ cells. Math.- Naturwiss. Diss. Göttingen 2005

Laird PW, Zijderveld A, Linders K, Rudnicki MA, Jaenisch R, Berns A (1991) : Simplified mammalian DNA isolation procedure. Nucleic Acids Res 19 (15): 4293.

Maldonado-Saldivia J, van den Bergen J, Krouskos M, Gilchrist M, Lee C, Li R, Sinclair AH, Surani MA, Western PS (2007): Dppa2 and Dppa4 are closely linked SAP motif genes restricted to pluripotent cells and the germ line. Stem Cells $\underline{25}$ (1): 19-28.

Martin GR, Evans MJ (1975): Differentiation of clonal lines of teratocarcinoma cells: formation of embryoid bodies in vitro. Proc Natl Acad Sci $\underline{72}$ (4): 1441-1445. 
Menke DB, Koubova J, Page DC (2003): Sexual differentiation of germ cells in XX mouse gonads occurs in an anterior-to-posterior wave. Dev Biol 262 (2): 303-312.

Miyamoto T, Sengoku K, Takuma N, Hasuike S, Hayashi H, Yamauchi T, Yamashita T, Ishikawa M (2002): Isolation and expression analysis of the testis-specific gene, STRA8, stimulated by retinoic acid gene 8. J Assist Reprod Genet 19 (11): 531-535.

Nagy A, Rossant J, Nagy R, Abramow-Newerly W, Roder JC (1993): Derivation of completely cell culture-derived mice from early-passage embryonic stem cells. Proc Natl Acad Sci 90 (18): 8424-8428.

Nayernia K, Li M, Jaroszynski L, Khusainov R, Wulf G, Schwandt I, Korabiowska M, Michelmann HW, Meinhardt A, Engel W (2004): Stem cell based therapeutical approach of male infertility by teratocarcinoma derived germ cells. Hum Mol Genet $\underline{13}$ (14): 1451-1460.

Nayernia K, Nolte J, Michelmann HW, Lee JH, Rathsack K, Drusenheimer N, Dev A, Wulf G, Ehrmann IE, Elliott DJ, Okpanyi V, Zechner U, Haaf T, Meinhardt A, Engel W (2006): In vitro-differentiated embryonic stem cells give rise to male gametes that can generate offspring mice. Dev Cell 11 (1): 125-132.

Nolte J: Versuche zur Differenzierung von embryonalen Stammzellen und Tumorzellen zu männlichen Keimzellen. Biologische Diplomarbeit Göttingen 2005

Nolte J: Zur Pluripotenz spermatogonialer Stammzellen. Math.- Naturwiss. Diss. Göttingen 2008 
Oulad-Abdelghani M, Bouillet P, Décimo D, Gansmuller A, Heyberger S, Dollé P, Bronner S, Lutz Y, Chambon P (1996): Characterization of a premeiotic germ cell-specific cytoplasmic protein encoded by Stra8, a novel retinoic acid-responsive gene. J Cell Biol 135 (2) 469-477.

Pesce M, Schöler HR (2001): Oct-4: gatekeeper in the beginnings of mammalian development. Stem Cells 19 (4): 271-278.

Saiki RK, Gelfand DH, Stoffel S, Scharf SJ, Higuchi R, Horn GT, Mullis KB, Erlich HA (1988): Primer-directed enzymatic amplification of DNA with a thermostable DNA polymerase. Science 239 (4839): 487-491.

Saitou M, Barton SC, Surani MA (2002): A molecular programme for the specification of germ cell fate in mice. Nature 418 (6895): 293-300.

Sambrook J, Fritsch EF, Maniatis T: Molecular cloning: a laboratory manual. 2. Auflage; Cold Spring Harbor, New York, USA 1989.

Sanger F, Nicklen S, Coulson AR (1977): DNA sequencing with chainterminating inhibitors. Proc Natl Acad Sci 74 (12): 5463-5467.

Sapin V, Bouillet P, Oulad-Abdelghani M, Dastugue B, Chambon P, Dolle P (1999): Differential expression of retinoic acid-inducible (Stra) genes during mouseplacentation. Mech Dev 92: 295-299.

Tedesco M, La Sala G, Barbagallo F, De Felici M, Farini D (2009): STRA8 shuttles between nucleus and cytoplasm and displays transcriptional activity. J Biol Chem 284 (51): 35781-35793.

Wang ZX, Kueh JL, Teh CH, Rossbach M, Lim L, Li P, Wong KY, Lufkin T, Robson P, Stanton LW (2007a) : Zfp206 is a transcription factor that controls pluripotency of embryonic stem cells. Stem Cells $\underline{25}$ (9): 21732182. 
Wang ZX, Teh CH, Kueh JL, Lufkin T, Robson P, Stanton L W (2007b): Oct4 and Sox2 directly regulate expression of another pluripotency transcription factor, Zfp206, in embryonic stem cells. J Biol Chem 282 (17): 12822-12830.

Western P, Maldonado-Saldivia J, van den Bergen J, Hajkova P, Saitou M, Barton S, Surani MA (2005): Analysis of Esg1 expression in pluripotent cells and the germline reveals similarities with Oct4 and Sox2 and differences between human pluripotent cell lines. Stem Cells $\underline{23}$ (10): 14361442.

Zechner U, Nolte J, Wolf M, Shirneshan K, Hajj NE, Weise D, Kaltwasser B, Zovoilis A, Haaf T, Engel W (2009): Comparative methylation profiles and telomerase biology of mouse multipotent adult germline stem cells and embryonic stem cells. Mol Hum Reprod 15 (6): 345-353.

Zhang W, Walker E, Tamplin OJ, Rossant J, Stanford WL, Hughes TR (2006): Zfp206 regulates ES cell gene expression and differentiation. Nucleic Acids Res $\underline{34}$ (17): 4780-4790.

Zhou Q, Li Y, Nie R, Friel P, Mitchell D, Evanoff RM, Pouchnik D, Banasik B, McCarrey JR, Small C, Griswold MD (2008a): Expression of stimulated by retinoic acid gene 8 (Stra8) and maturation of murine gonocytes and spermatogonia induced by retinoic acid in vitro. Biol Reprod $\underline{78}$ (3): 537-545.

Zhou Q, Nie R, Li Y, Friel P, Mitchell D, Hess RA, Small C, Griswold MD (2008b): Expression of stimulated by retinoic acid gene 8 (Stra8) in spermatogenic cells induced by retinoic acid: an in vivo study in vitamin Asufficient postnatal murine testes. Biol Reprod $\underline{79}$ (1): 35-42. 
Zovoilis A, Nolte J, Drusenheimer N, Zechner U, Hada H, Guan K, Hasenfuss G, Nayernia K, Engel W (2008): Multipotent adult germline stem cells and embryonic stem cells have similar microRNA profiles Mol Hum Reprod 14 (9): 521-529. 


\section{Danksagung}

An dieser Stelle möchte ich mich bei Herrn Prof. Dr. Dr. W. Engel für die Bereitschaft bedanken, diese Arbeit zu betreuen. Vielen Dank für die intensive Betreuung, die vielen Anregungen und für die zügige Korrektur des Manuskripts.

Ein besonderer Dank gilt auch Frau Dr. J. Nolte für die Bereitstellung des Themas, für die vielen Anregungen, ihre umfassende Unterstützung bei der Versuchsplanung und -durchführung und die gute Zusammenarbeit, die sehr zu meiner Motivation und zum Gelingen dieser Arbeit beigetragen haben.

Mein Dank gilt auch meinen Kollegen aus dem Labor 107 für die gute Zusammenarbeit und die gute Atmosphäre. Insbesondere bedanke ich mich bei Nadja und Sandra, die mir immer hilfsbereit mit Rat und Tat zur Seite standen. Es hat mir sehr viel Spaß gemacht, mit Euch in dieser Arbeitsgruppe zu arbeiten.

Danke natürlich auch an alle anderen Mitarbeiter des Instituts für Humangenetik. 


\section{Lebenslauf}

Mein Name ist Linda Kotzenberg. Ich wurde am 04. Juli 1983 als drittes von vier Kindern des Leiters der "Werkstätten für behinderte Menschen“ der Lebenshilfe Detmold e.V., Dipl. Ing. Jochen Kotzenberg, und der Hausfrau Hildegard Kotzenberg, geborene Reinsch, in Steinheim geboren.

Von 1990-1994 besuchte ich die Werretalschule Remmighausen. Anschließend war ich Schülerin der Geschwister - Scholl - Gesamtschule Detmold, an der ich 2003 meine allgemeine Hochschulreife erlangte.

Nach meiner Schulzeit absolvierte ich zunächst ein zweimonatiges Pflegedienstpraktikum. Da ich ein Jahr auf einen Studienplatz für das Studium zur Humanmedizin warten musste, nutzte ich diese Zeit, um diversen kleineren Beschäftigungen nachzugehen. Unter anderem arbeitete ich als Praktikantin in einer Kommunikationsagentur, wo ich bei dem Erstellen von Pressespiegeln half, danach in einer Fabrik für Pyrotechnik. Außerdem unterstützte ich eine ältere Dame nach dem Tode ihres Mannes. Zudem verbesserte ich meine Englischkenntnisse durch einen zweimonatigen Sprachkurs auf Malta.

Im Wintersemester 2004/2005 begann ich mein Humanmedizinstudium an der Georg-August-Universität Göttingen, das ich voraussichtlich im Wintersemester 2010/2011 abschließen werde. Währenddessen absolvierte ich diverse Praktika und Famulaturen in unterschiedlichsten Fachgebieten und Städten, unter anderem auch eine zweimonatige Famulatur in der Geburtshilfe bzw. Notfallaufnahme in Port Shepstone, Südafrika. Von Dezember 2007 bis August 2009 arbeitete ich parallel zu meinem Studium, unter der Leitung von Prof. Dr. med. Dr. h.c. W. Engel, an der vorliegenden experimentellen Arbeit zur Dissertation am Institut für Humangenetik der Georg-August-Universität Göttingen. 

